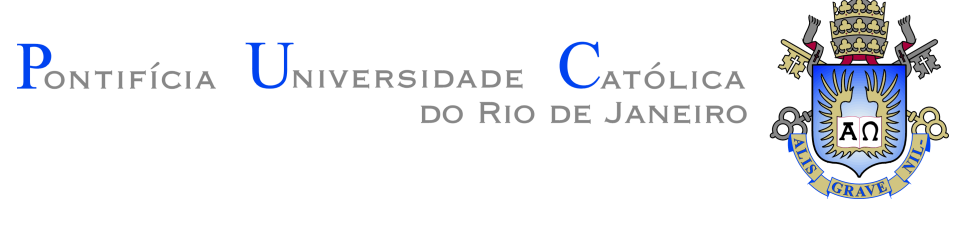

Luiz Felippe Medeiros de Almeida

Modelagem termo-mecânica do crescimento de
pressão em anulares confinados, frente a
formações salinas

Dissertação de Mestrado

Dissertação apresentada como requisito parcial para obtenção do grau de Mestre pelo Programa de Pós-graduação em Petróleo e Energia do Departamento de Engenharia Mecânica do Centro Técnico Científico da PUC-Rio.

Orientador : Prof. Jaime Tupiassú Pinho de Castro Coorientador: Prof. Eurípedes do Amaral Vargas Júnior 

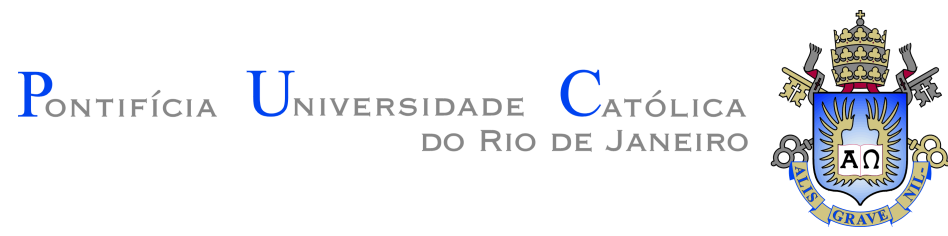

Luiz Felippe Medeiros de Almeida

\section{Modelagem termo-mecânica do crescimento de pressão em anulares confinados, frente a formações salinas}

Dissertação apresentada como requisito parcial para obtenção do grau de Mestre pelo Programa de Pós-graduação em Petróleo e Energia do Departamento de Engenharia Mecânica do Centro Técnico Científico da PUC-Rio. Aprovada pela Comissão Examinadora abaixo assinada.

Prof. Jaime Tupiassú Pinho de Castro Orientador Departamento de Engenharia Mecânica - PUC-Rio

Prof. Eurípedes do Amaral Vargas Júnior Coorientador Departamento de Engenharia Civil - PUC-Rio

Prof. Arthur Martins Barbosa Braga Departamento de Engenharia Mecânica - PUC-Rio

Dr. Emilio César Cavalcante Melo da Silva Petrobras -

Prof. Márcio da Silveira Carvalho Coordenador Setorial do Centro Técnico Científico - PUC-Rio 
Todos os direitos reservados. É proibida a reprodução total ou parcial do trabalho sem autorização da universidade, do autor e do orientador.

\section{Luiz Felippe Medeiros de Almeida}

Graduado em Engenharia Mecânica no Instituto Militar de Engenharia (IME, 2010). Cursou especialização em Engenharia de Petróleo na Universidade Petrobras - UP(2012). Atuou como fiscal de sonda durante o período entre 2012 e 2013. Atualmente trabalha como pesquisador no Centro de Pesquisas da Petrobras (CENPES), na área de geomecânica.

Ficha Catalográfica

Almeida, Luiz Felippe Medeiros de

Modelagem termo-mecânica do crescimento de pressão em anulares confinados, frente a formações salinas / Luiz Felippe Medeiros de Almeida; orientador: Jaime Tupiassú Pinho de Castro; co-orientador: Eurípedes do Amaral Vargas Júnior. - 2016.

v., 90 f: il. ; $30 \mathrm{~cm}$

Dissertação (mestrado) - Pontifícia Universidade Católica do Rio de Janeiro, Departamento de Engenharia Mecânica.

Inclui bibliografia

1. Engenharia de Petróleo. 2. Engenharia de Poço. 3. Sal. 4. Fluência. 5. Crescimento de pressão. I. Castro, Jaime Tupiassú Pinho de. II. Júnior, Eurípedes do Amaral Vargas. III. Pontifícia Universidade Católica do Rio de Janeiro. Departamento de Engenharia Mecânica. IV. Título. 


\section{Agradecimentos}

Em primeiro lugar, agradeço a Deus pela concretização de mais uma vitória em minha vida.

Agradeço a minha esposa Verônica pelo amor, carinho e incentivo durante essa jornada e pela compreensão nos momentos despendidos em função das atividades acadêmicas.

Agradeço aos meus orientadores por todo suporte necessário.

Agradeço à Petrobras pela oportunidade e confiança concedida, contribuindo para o meu desenvolvimento em minha área de atuação.

Por fim e não menos importante, agradeço aos meus colegas de trabalho do CENPES, em especial ao Jorel Lopes e ao Emílio Silva, pelas incontáveis horas de suporte no desenvolvimento deste trabalho. 


\section{Resumo}

Almeida, Luiz Felippe Medeiros de; Castro, Jaime Tupiassú Pinho de ; Júnior, Eurípedes do Amaral Vargas. Modelagem termomecânica do crescimento de pressão em anulares confinados, frente a formações salinas. Rio de Janeiro, 2016. 90p. Dissertação de Mestrado - Departamento de Engenharia Mecânica, Pontifícia Universidade Católica do Rio de Janeiro.

Este trabalho apresenta uma modelagem numérica termo-mecânica para investigação da influência da presença da rocha salina no acréscimo de pressão em anulares confinados (APB). O fenômeno de APB é resultado da expansão térmica do fluido de perfuração trapeado nos anulares do poço, induzida pelo aquecimento gerado pela produção de hidrocarbonetos em temperatura superior ao restante do poço. Os evaporitos são formações que possuem um comportamento mecânico viscoelástico, apresentando deformação contínua a partir de uma tensão constante, processo conhecido como fluência. Este comportamento do sal não é atualmente considerado pelos simuladores utilizados pela indústria do petróleo durante o projeto de poços, no que tange dimensionamento para esta carga de pressão proveniente do APB. O objetivo deste trabalho é alcançado pelo desenvolvimento uma metodologia de cálculo do fenômeno de APB frente a formações salinas, através de um modelo numérico construído no software ABAQUS, utilizando o método dos elementos finitos. Diversas simulações foram realizadas com configurações distintas de litologia, temperatura e fluidos de perfuração, para analisar a influência do comportamento viscoelástico da rocha salina no crescimento de pressão em anulares confinados. Após análise de resultados obtidos, se concluiu que a rocha salina pode agir como aliviador da pressão gerada pela expansão térmica do fluido de perfuração confinado nos anulares do poço. As tensões geradas pelo APB levam a deformações de fluência que aumentam o diâmetro do poço e consequentemente o volume anular, acomodando parte do acréscimo de pressão gerado.

\section{Palavras-chave}

Engenharia de Petróleo; Engenharia de Poço; Sal; Fluência; Crescimento de pressão; 


\section{Abstract}

Almeida, Luiz Felippe Medeiros de; Castro, Jaime Tupiassú Pinho de (Advisor); Júnior, Eurípedes do Amaral Vargas (Co-Advisor). Thermomechanical modeling of annular pressure build up in salt formations. Rio de Janeiro, 2016. 90p. MSc. Dissertation - Departamento de Engenharia Mecânica, Pontifícia Universidade Católica do Rio de Janeiro.

This dissertation presents a thermo-mechanical numerical modeling to investigate the influence of the presence of salt rock on annular pressure build-up (APB). The APB phenomenon is a result of thermal expansion of confined drilling fluid in the well annulus, induced by heat generated by the production of hydrocarbons at temperatures above the remainder of the well. The evaporite formations have a viscoelastic mechanical behavior, with continuous deformation at constant stress, known as creep. This salt behavior is not currently considered by simulators used by the oil industry for the design of wells, with respect to this pressure load from APB. The objective is achieved by developing a methodology for calculating the APB effect for wells with saline formations, using a numerical model built in ABAQUS software, using the finite element method. Several simulations were performed with different configurations of lithology, temperature and drilling fluids, to analyze the influence of the viscoelastic behavior of the salt rock on pressure growth in confined annuli. After analyzing the results, it was concluded that the rock salt may act as a relief for the pressure generated by thermal expansion of the confined drilling fluid in the well annulus. The stresses generated by the APB lead to creep strains that increase the well diameter and consequently the annular volume, accommodating part of the generated pressure increase.

\section{Keywords}

APB; Annular Pressure Build Up; Salt Formations; Creep; FEA; Well Design; 


\section{Sumário}

1 Introdução $\quad 15$

2 Revisão bibliográfica $r$

$\begin{array}{lll}2.1 & \text { Fenômeno de APB } & 19\end{array}$

2.1.1 Métodos de mitigação 20

2.1.1.1 Alívio de pressão 21

2.1.1.2 Aumento da resistência estrutural 21

2.1.1.3 Aumento da compressibilidade do fluido 21

2.1.1.4 Isolamento térmico 21

2.1.2 Modelagem matemática de APB 22

2.2 Evaporitos 24

2.2.1 Fluência de evaporitos 27

$\begin{array}{ll}2.2 .2 \text { Comportamento dos evaporitos } & 29\end{array}$

2.2.3 Modelo constitutivo 31

3 Modelo numérico $\quad 35$

3.1 Geração do modelo 36

3.2 Geometria 36

3.2.1 Borda do modelo 38

3.3 Materiais utilizados 40

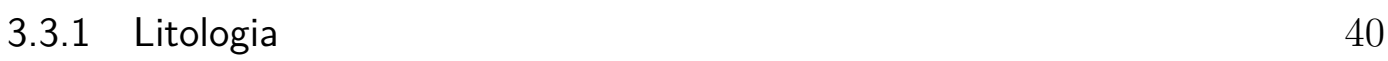

3.3.1.1 Revestimentos $\quad 42$

3.3.1.2 Fluido de perfuração 43

3.4 Malha de elementos finitos 44

3.5 Condições de contorno 46

3.6 Condições iniciais 47

$\begin{array}{lll}\text { 3.6.1 Pressão de fluido } & 47\end{array}$

3.6.2 Estado de tensão do revestimento 48

3.6.3 Estado de tensão da rocha 50

4 Metodologia de Simulação $\quad 52$

4.1 Construção do poço $\quad 52$

4.1.1 Perfuração $\quad 52$

$\begin{array}{lll}\text { 4.1.2 Descida de revestimento } & 54\end{array}$

4.2 Produção e fenômeno de APB 54

4.2.1 Expansão térmica $\quad 57$

$\begin{array}{lll}\text { 4.2.1.1 Pressurização do anular } & 59\end{array}$

5 Resultados $\quad 60$

5.1 Caso base 60

5.1.1 Modelo elástico $\quad 61$

5.1.2 Modelo viscoelástico 64

$\begin{array}{lll}5.2 & \text { Sal de alta mobilidade } & 69\end{array}$

$\begin{array}{lll}5.3 & \text { Efeito do peso de fluido } & 74\end{array}$ 
$\begin{array}{lll}\text { 5.4 Poços de alta temperatura } & 79\end{array}$

6 Conclusão $\quad 84$

$\begin{array}{lll}6.1 & \text { Considerações gerais } & 84\end{array}$

6.2 Conclusões 84

6.3 Sugestões e trabalhos futuros 86

$\begin{array}{lr}\text { Referências bibliográficas } & 87\end{array}$ 


\section{Lista de figuras}

1.1 Preço do barril de óleo Brent no mercado internacional de 2011 a 2015 em US\$ por barril (1).

1.2 Esquema de formações de um poço do Pré-Sal

1.3 Esquema de poço ilustrando os espaços anulares de um poço de petróleo e o sentido do fluxo de óleo pela coluna.

1.4 Colapso do revestimento de $16^{\prime \prime}$ durante a circulação do poço Pompano (A-31) (10).

2.1 Perfil térmico de um poço do pré sal antes e após produção.

2.2 Relação entre a pressão devido ao fenômeno de APB e a vazão de produção (15).

2.3 Comparação do crescimento de pressão para fluidos espumados (10). 22

2.4 Esquema de um VIT.

2.5 Crescimento de pressão em um recipiente elástico (18). 24

2.6 Geração de óleo e gás aprisionado por formação capeadora.

2.7 Simulação numérica do fechamento radial de um poço com presença de rocha salina (27).

2.8 Aumento das tensões de von Mises da coluna de revestimento levando ao colapso do mesmo (28).

2.9 Ocorrências durante a perfuração de rocha salina. 26

2.10 Estágios da curva de deformação por fluência. 27

2.11 Taxa de deformação ao longo das fases de fluência do material. $\quad 28$

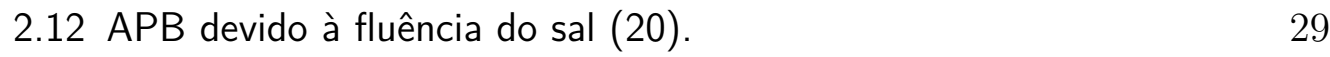

2.13 Redução do diâmetro do poço devido à fluência do sal (20). 30

2.14 Alívio de pressão devido à fluência do sal (21). 31

2.15 Mapa de mecanismos de deformação secundária (37). 32

2.16 Taxas de deformação em regime permanente (33). 34

3.1 Modelo numérico englobando a construção e produção do poço de petróleo.

3.2 Fluxograma de construção do arquivo de simulação no ABAQUS. 36

3.3 Geometria padrão que representa um poço fictício do Pré-Sal. 37

3.4 Vista axissimétrica da geometria do modelo, com destaque para os revestimentos utilizados.

3.5 Esquema da nomenclatura dos anulares.

3.6 Tensão de von Mises ao longo da direção radial imediatamente após a perfuração do poço.

3.7 Tensão de von Mises ao longo da direção radial após 6 meses. $\quad 40$

3.8 Trecho do perfil litológico de um poço de petróleo (39). 41

3.9 Esquema das dimensões de um tubo de revestimento. 42

3.10 Malha de elementos finitos com refinamento na direção radial. 44

3.11 Curvas de fluência para um ponto da parede do poço e base do sal, durante o período de 6 meses após a perfuração da fase.

3.12 Condições de contorno da coluna de revestimento. 46

3.13 Condições de contorno da rocha. 
3.14 Carregamentos sobre a coluna de revestimento. 49

3.15 Tensão axial da coluna de revestimento. 49

3.16 Estado de tensões in-situ na rocha (39). 50

3.17 Tensão de sobrecarga para o poço padrão. 51

4.1 Pressão de fluido aplicada na parede do poço durante a etapa de perfuração. Na esquerda, uma vista axissimétrica do modelo e na direita, um corte da seção transversal.

4.2 Estado de tensão pós perfuração para a profundidade do ponto de controle a 2170 metros.

4.3 Tensão axial do revestimento de 30".

4.4 Perfil térmico após 4096 horas em comparação com o perfil de equilíbrio.

4.5 Perfis térmicos para os tempos $t_{i}$. 56

4.6 Fluxograma da rotina de expansão térmica. 57

4.7 Expansão volumétrica de um volume de controle. 58

4.8 Fluxograma de cálculo da compatibilização de pressão anular. $\quad 59$

5.1 Resumo da geometria do caso base.

5.2 Perfis de temperatura simulados pelo software Wellcat para o fluido do anular A.

5.3 Perfis de temperatura simulados pelo software Wellcat para o fluido do anular B.

5.4 Evolução do acréscimo de pressão nos anulares $A$ e $B$ para o caso puramente elástico.

5.5 Tensão de von Mises e deslocamento radial dos pontos localizados na parede do poço, ao longo do trecho salino.

5.6 Deslocamento da parede do poço ao longo de 6 meses, na base do sal.

5.7 Variação volumétrica e de pressão no anular $A$, durante os 6 meses anteriores ao início da produção.

5.8 Evolução do acréscimo de pressão devido ao fenômeno de APB.

5.9 Deformação por fluência durante o período total de simulação, para a profundidade de $4456 \mathrm{~m}$.

5.10 Ampliação, durante as primeiras 16 horas do início do aquecimento, da tensão e deformação por fluência.

5.11 Tensões em pontos localizados ao longo da parede do poço no instante do início da produção.

5.12 Representação do pacote de carnalita no modelo numérico.

5.13 Variação de pressão e volume do anular A durante o período de 6 meses até o início da produção, para o caso com lente de carnalita.

5.14 Comportamento da tensão de Mises para um ponto a $3459 \mathrm{~m}$ (topo da carnalita) e da pressão do anular A, nos dois primeiros meses de simulação.

5.15 Deslocamento da parede do poço para um ponto a $3469 \mathrm{~m}$, na carnalita.

5.16 Comparação do crescimento de pressão em ambos anulares para o caso base e com a presença da lente de carnalita. 
5.17 Tensão de von Mises na parede do poço ao longo da fase do sal, para os diferentes casos de peso de fluido, imediatamente após a perfuração.

5.18 Variação de pressão do anular A no período inicial de 6 meses para os casos de fluido leve e pesado.

5.19 Acréscimo de pressão dos anulares A e B para os casos com pesos de fluido distintos.

5.20 Tensões na parede do poço a $4456 \mathrm{~m}$ para o caso de $9 \mathrm{ppg}$, durante as 16 primeiras horas de produção.

5.21 Tensão de von Mises para as $16 \mathrm{~h}$ iniciais de produção.

5.22 Variação de pressão do anular A durante os 6 meses anteriores a produção, para o caso base e de alta temperatura.

5.23 Deslocamento radial da parede do poço, para a profundidade de $4456 \mathrm{~m}$.

5.24 Acréscimo de pressão durante a produção do poço para o caso base e de alta temperatura. 


\section{Lista de tabelas}

3.1 Parâmetros geométricos do poço padrão. 37

3.2 Propriedades mecânicas das rochas utilizadas. 41

3.3 Constantes do modelo de fluência de duplo mecanismo. 42

3.4 Propriedades das colunas de revestimento. 43

3.5 Pesos de fluido utilizados para a construção do poço padrão. 43

3.6 Propriedades térmicas dos fluidos de perfuração utilizados. 43

3.7 Deformação de fluência após 6 meses. 45

3.8 Valores de K utilizados no modelo numérico. 51

4.1 Estado de tensão inicial do ponto de controle. 53

4.2 Temperaturas iniciais para o poço padrão. 55

5.1 Propriedades dos fluidos utilizados no caso base 60

5.2 Resumo de condições de tensão e temperatura do sal. 61

5.3 Variação volumétrica irrestrita total, após término do aquecimento 63

5.4 Expansão volumétrica para o caso base. 63

5.5 Variação de pressão para os casos elásticos e considerando comportamento de fluência da rocha salina. 67

5.6 Variação máxima de pressão para os casos base e com presença de lente de carnalita.

5.7 Expansão volumétrica para o caso de fluido leve (9 ppg). $\quad 77$

5.8 Expansão volumétrica para o caso de fluido pesado (13 ppg). $\quad 77$

5.9 Expansão volumétrica para o caso de alta temperatura. 


\section{Lista de Abreviaturas}

\section{Letras romanas}

A - Área

APB - Annular pressure build-up

BP - Britsh Petroleum

CAX4T - Elemento finito de 4 nós, bilinear e com grau de liberdade de deslocamento e temperatura

$C_{P}$ - Compressibilidade isotérmica

$C_{T}$ - Coeficiente de expansão térmica

D - Diâmetro

e - Espessura

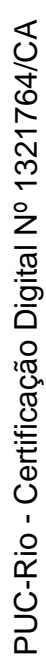

E - Módulo de Young

g - aceleração da gravidade

$\mathrm{H}$ - Altura

$\mathrm{m}$ - massa

$\mathrm{n}$ - expoente que depende da tensão

$\mathrm{P}$ - Pressão

$P_{H}$ - Pressão hidrostática

Q - Energia de ativação

Q - Vazão mássica

$\mathrm{R}$ - Constante universal dos gases

$\mathrm{t}$ - Tempo

$\mathrm{T}$ - Temperatura

$T_{0}$ - Temperatura de referência

$T_{m}$ - Temperatura de fusão do material

TOC - Profundidade de topo do cimento

$\mathrm{V}$ - Volume

$V_{a n}$ - Volume anular

VIT - Vacuum insulated tubing

W - Peso linear

\section{Letras gregas}


$\Delta$ - Variação

$\epsilon$ - Deformação

$0 \dot{\epsilon_{0}}-$ Taxa de deformação de referência

$\epsilon_{e}-$ Deformação elástica

$\dot{\epsilon}$ - Taxa de deformação

$\mu$ - Módulo de cisalhamento

$\nu$ - Coeficiente de poisson

$\rho$ - Densidade

$\sigma$ - Tensão normal

$\sigma_{0}-$ Tensão efetiva de referência

$\sigma_{e f}$ - Tensão efetiva de fluência

$\tau$ - Tensão de cisalhamento 


\section{Introdução}

O cenário para a indústria do petróleo no Brasil é cada vez mais desafiador, tanto sob o ponto de vista econômico quanto sob o ponto de vista técnico. O preço do barril de petróleo tem sofrido quedas no mercado internacional, chegando ao patamar de US\$ 30 (1), reduzindo as margens de lucro e promovendo uma maior busca de eficiência operacional e gestão de capital. O gráfico da figura 1.1 apresenta a queda do valor do barril de óleo no mercado internacional.

Em paralelo, o foco da produção de petróleo no Brasil é cada vez mais direcionado a poços de águas profundas e ultra profundas, que possuem elevados custos para sua construção e grandes desafios tecnológicos em sua engenharia. Essa combinação de fatores leva ao desenvolvimento de projetos cada vez mais robustos sob o ponto de vista da engenharia de poços, para que os mesmos sejam construídos da maneira mais eficiente possível e com menor ocorrência de problemas que gerem custos ou impactem na segurança do empreendimento.

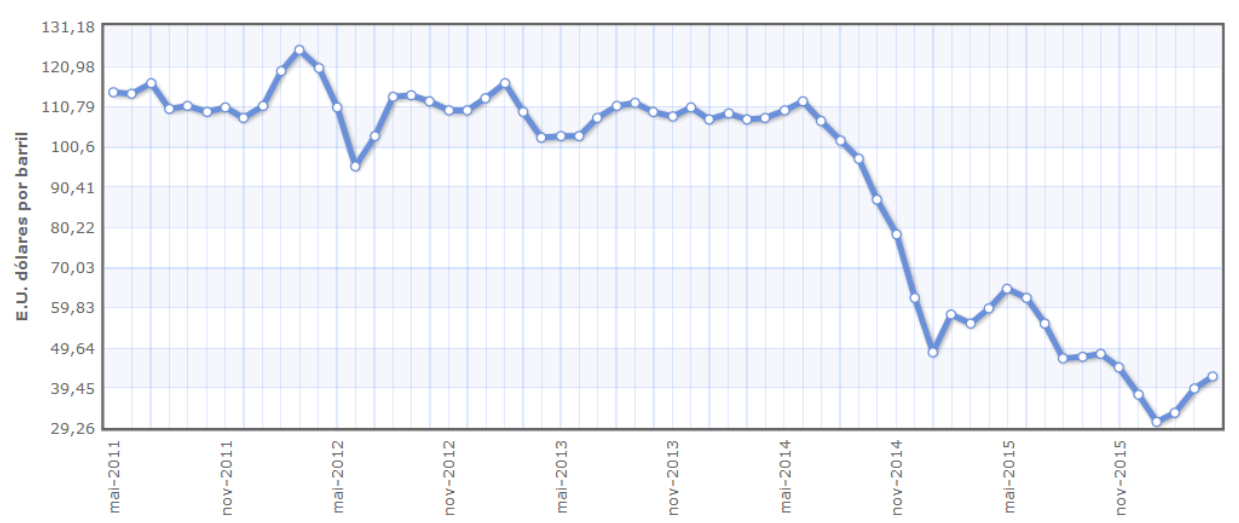

Figura 1.1: Preço do barril de óleo Brent no mercado internacional de 2011 a 2015 em US\$ por barril (1).

No contexto de poços de águas profundas e ultra profundas se encontram os poços do Pré-Sal, que contribuem com uma produção da ordem de 1 milhão de barris por dia de petróleo e gás (2) e que em 2018, segundo previsão da Petrobras, devem representar $52 \%$ da produção de petróleo no Brasil (3). Tais poços podem alcançar o comprimento total de 7000 metros e são caracterizados 
pela presença de formação evaporítica (sal) com espessura de até 2000 metros. A figura 1.2 ilustra o esquema de formações de um poço do Pré-Sal.

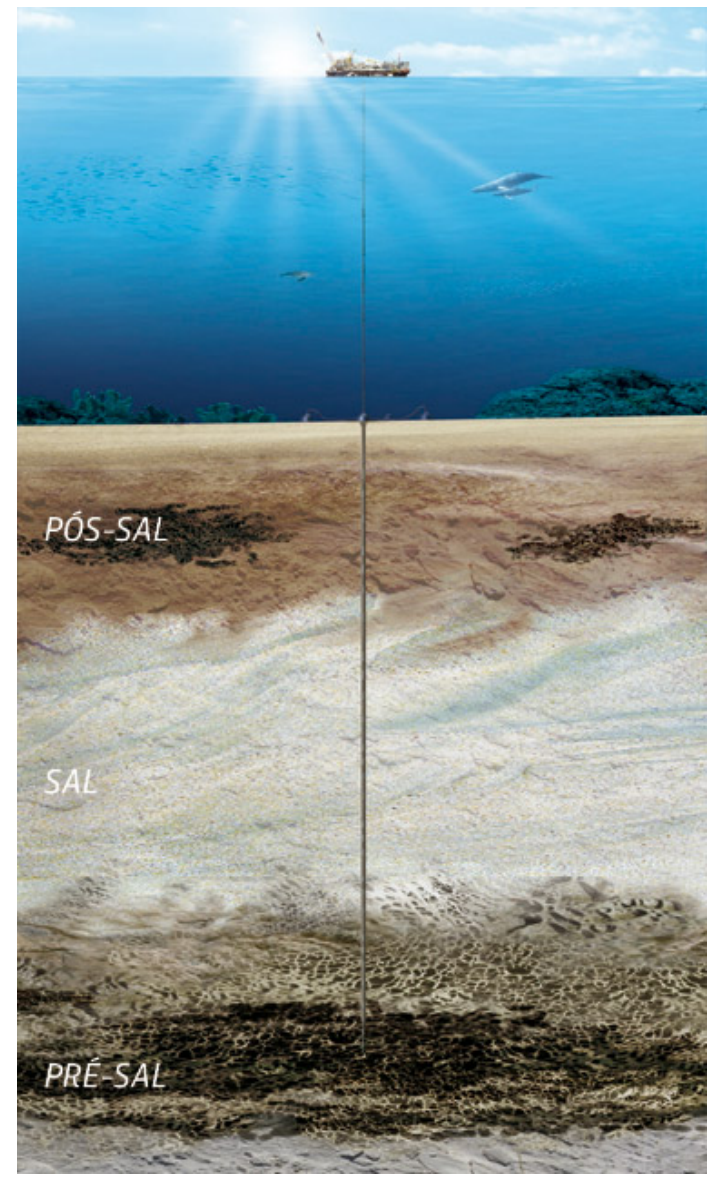

Figura 1.2: Esquema de formações de um poço do Pré-Sal

As rochas salinas são praticamente impermeáveis, formando uma eficiente estrutura capeadora e aumentando a chance de se encontrar bons reservatórios de hidrocarbonetos. No entanto, tais formações proporcionam dificuldades para a perfuração dos poços devido ao fenômeno de fluência, que é caracterizado por uma deformação contínua sob tensão constante. O fechamento da parede do poço pela fluência do sal pode gerar eventos de prisão da coluna de perfuração, dificuldade na descida do revestimento e esforços de compressão ao longo da vida útil do mesmo.

Os poços marítimos de grande profundidade, como os de determinados campos do Pré-Sal, possuem altas temperaturas no reservatório, visto que a temperatura tende a aumentar com a profundidade, e baixas temperaturas no leito marinho (aproximadamente $4^{\circ} \mathrm{C}$ ) (4) . A diferença de temperatura entre o óleo que escoa pela coluna de produção e o poço ao redor gera uma troca térmica entre ambos. Esta carga térmica leva a expansão do fluido compreendido no espaço anular do poço que tende a sofrer uma expansão térmica e consequentemente a um aumento de pressão, pois o mesmo encontra- 
se confinado entre a cabeça do poço e o topo do cimento (5), como ilustra a figura 1.3.

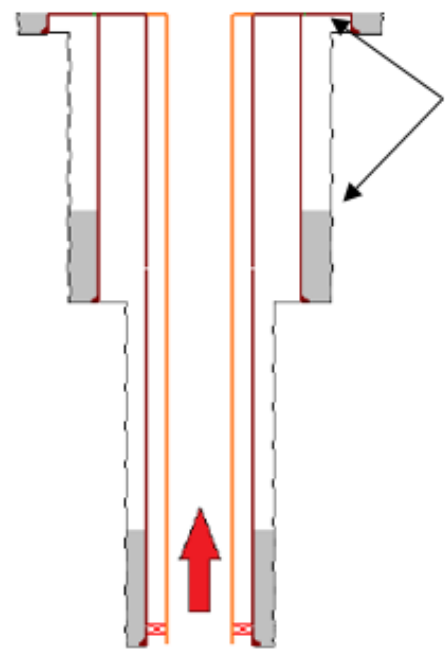

Fluido confinado entre topo do cimento e cabeça do poço

Figura 1.3: Esquema de poço ilustrando os espaços anulares de um poço de petróleo e o sentido do fluxo de óleo pela coluna.

O aumento de pressão nos espaços anulares de um poço ou "Annular Pressure Build-up" (APB) é um problema conhecido da indústria do petróleo e é estudado desde a década de 90 (6). O dimensionamento dos equipamentos do poço e sua coluna de revestimento deve levar em consideração esta carga adicional proveniente do fenômeno de APB, para garantir a integridade mecânica do sistema.

Há casos de falhas em poços de petróleo, nos quais a causa mais provável foi APB. A British Petroleum (BP) em 1999 teve um problema no poço Marlim (A-2), no qual, logo após o início da produção, o tieback do revestimento de produção colapsou $(7,8)$. Este fenômeno pode acontecer inclusive durante a perfuração do poço. No poço de Pompano (A-31) localizado no golfo do México, ocorreu o colapso do revestimento de $16^{\prime \prime}$ e prisão da coluna de perfuração durante a circulação do fluido de perfuração (9) (figura 1.4).
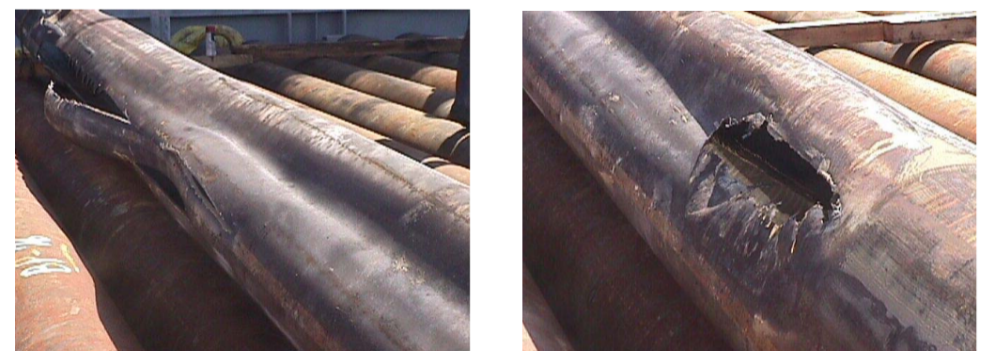

Figura 1.4: Colapso do revestimento de $16^{\prime \prime}$ durante a circulação do poço Pompano (A-31) (10). 
A presença da rocha salina e a sua característica de fluência gera mais um fator de alteração de pressão do anular. A depender do estado de tensão in-situ e da pressão exercida na parede do poço, o sal pode fluir no sentido de reduzir ou aumentar o diâmetro do poço, aumentando ou aliviando a pressão do fluido trapeado no anular. Este mecanismo não é incorporado na formulação clássica proposta por Oudeman (11).

A metodologia de cálculo proposta neste trabalho inclui este efeito na modelagem do fenômeno de APB, de forma a investigar a influência da rocha salina e seu comportamento viscoelástico no desenvolvimento das pressões em anulares confinados. Foi adotado um caso base que representa um poço típico do Pré-Sal, tanto sob o ponto de vista de construção (geometria e configuração litológica), quanto vazão e condições de produção. O resultado do cálculo do acréscimo de pressão gerado pelo fenômeno de APB, para este caso base, foi avaliado considerando o modelo clássico e a inclusão do comportamento viscoelástico da rocha salina. Este objetivo foi atingido através do desenvolvimento de um modelo numérico termo-mecânico em elementos finitos, utilizando o software ABAQUS (40). 


\section{2}

\section{Revisão bibliográfica}

\section{1}

\section{Fenômeno de APB}

O crescimento de pressão em anulares confinados (APB) é fruto da expansão térmica do fluido trapeado nos anulares do poço (12). A produção de óleo do reservatório, que se encontra a uma temperatura superior ao restante do poço, gera um aumento da temperatura ao longo da coluna de produção e do seu entorno. O perfil térmico de um poço marítimo do Pré-Sal ilustrado pela figura 2.1, exemplifica a diferença de temperatura inicial e pós equilíbrio térmico dado o início da produção.

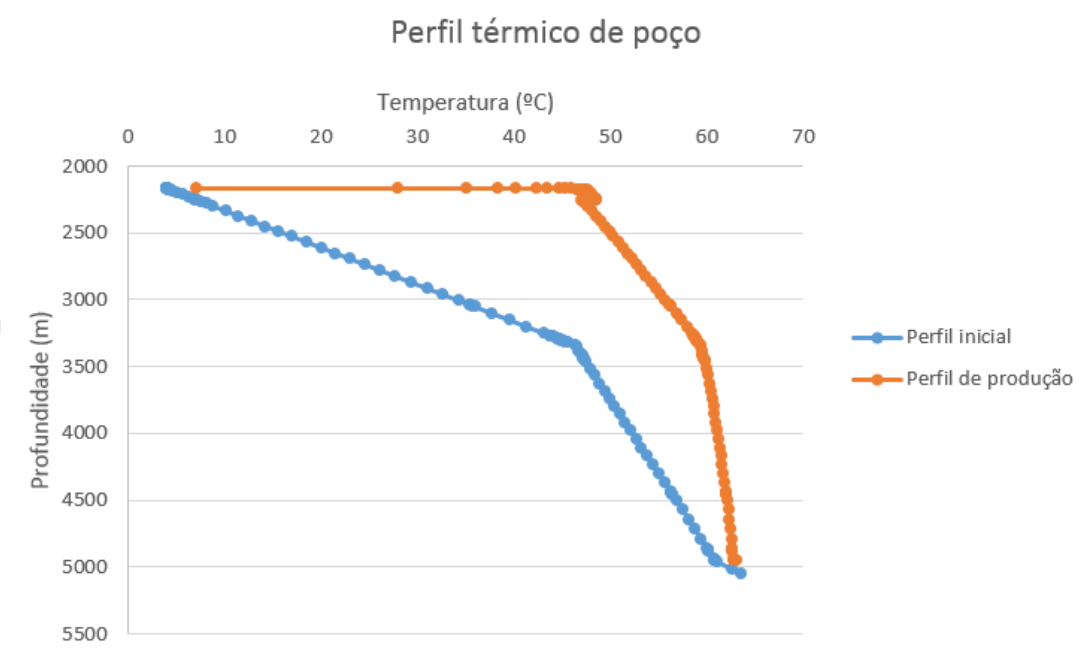

Figura 2.1: Perfil térmico de um poço do pré sal antes e após produção.

Devido a natureza incompressível do fluido de completação e/ou de perfuração que se encontram nos anulares do poço, uma pequena variação de temperatura ou de volume do anular pode gerar grandes aumentos de pressão. A depender da condição inicial na cabeça de poço, variações de temperatura de $83{ }^{\circ} \mathrm{C}$ e até 10000 psi de pressão podem ocorrer (13).

Drenar a pressão através de válvulas da cabeça do poço como é feito rotineiramente em poços terrestres, não é possível em poços submarinos $(4,14)$. Poços marítimos necessitam da intervenção de uma sonda para que esta pressão 
possa ser aliviada, o que por si só é um fator complicador e possui alto custo associado.

Essa carga extra de pressão pode comprometer a integridade do poço, ocasionando colapso de revestimento, fratura da formação e o vazamento do selo de vedação da cabeça do poço (pack-off). Em determinadas situações a redução da vazão de produção do poço pode ser necessária, a fim de diminuir a pressão do anular, visto que a carga de pressão de APB tende a aumentar com a vazão de produção do poço como mostra a figura $2.2(15,16)$. Em casos extremos pode ocorrer a perda do poço, gerando grande prejuízo financeiro (17).

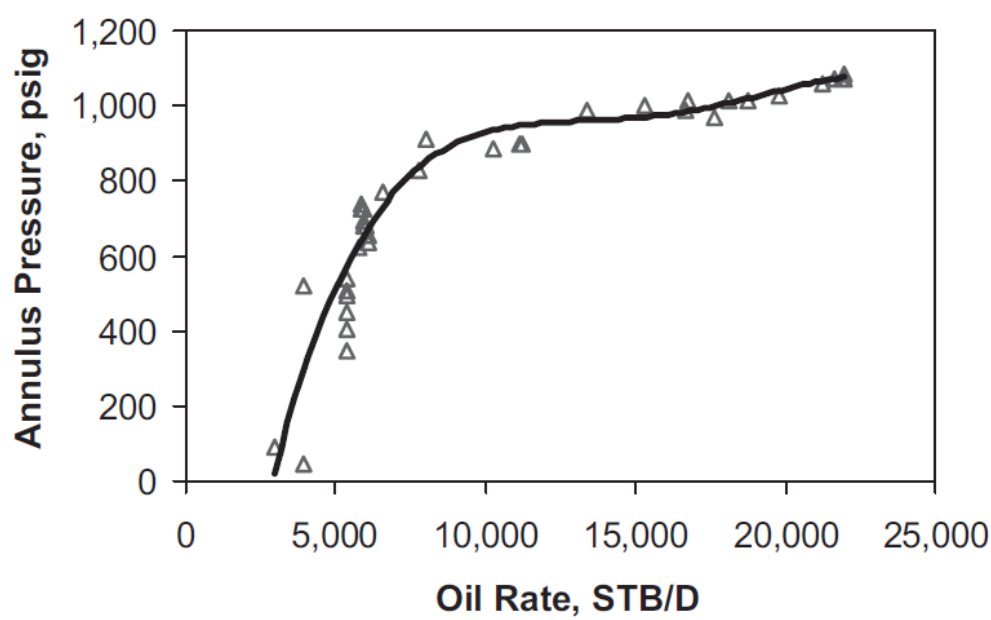

Figura 2.2: Relação entre a pressão devido ao fenômeno de APB e a vazão de produção (15).

\subsection{1}

\section{Métodos de mitigação}

Conforme citado anteriormente, o crescimento de pressão em anulares confinados pode implicar em uma série de problemas de ordem estrutural e/ou financeira. No entanto, existem diversas técnicas para mitigar o problema de APB, anulando o crescimento de pressão ou reduzindo seu valor para patamares aceitáveis para o conjunto mecânico em questão. Os métodos de mitigação atuam principalmente no sentido de dificultar o aquecimento do fluido no anular ou promover a sua drenagem para anulares vizinhos ou formação (18). As técnicas podem ser classificadas em quatro grupos distintos:

\subsubsection{1}




\section{Alívio de pressão}

Tais métodos promovem a redução de massa do anular através de sua drenagem para anulares adjacentes ou para formação. Pode se citar:

- Sapata aberta: O topo do cimento (TOC) se encontra em uma profundidade superior à sapata anterior, deixando formação exposta que dependendo de seu gradiente de fratura age como fusível, protegendo o revestimento e o pack-off na cabeça do poço. Este costuma ser o método mais utilizado em poços submarinos (14).

- Discos de ruptura: São discos que, colocados na coluna de revestimento, se rompem com determinada pressão de projeto e comunicam anulares adjacentes, promovendo o alívio da pressão.

- Canhoneio: Uma ferramenta de canhoneio (canhão) é descida no poço e através de uma explosão direcionada, rompe o revestimento e o cimento interligando o anular com a formação, a qual poderá agir como estrutura de sacrifício.

\subsubsection{2}

\section{Aumento da resistência estrutural}

Tubulares de maior resistência são selecionados de forma a suportar essa carga extra vinda do APB. São utilizados tubulares de maior espessura e/ou maior resistência. Analogamente, pack-off's de maior classe de pressão são empregados.

\subsubsection{3}

\section{Aumento da compressibilidade do fluido}

O objetivo desse grupo de técnicas é aumentar a compressibilidade do sistema, reduzindo a pressão final após o aquecimento do fluido. Por exemplo, podem ser utilizados fluidos de alta compressibilidade ou colchões de espuma (10). A figura 2.3 ilustra a diferença da evolução da pressão em anular confinado para diferentes tipos de fluidos espumados.

\subsubsection{4}

\section{Isolamento térmico}

O isolamento térmico tem por função reduzir a troca de calor entre óleo e/ou gás em alta temperatura que flui pela coluna de produção e o seu entorno.

Uma das alternativas largamente utilizadas na indústria do petróleo são os VIT (vacuum insulated tubing) (19). A figura 2.4 ilustra o design típico de um VIT. 


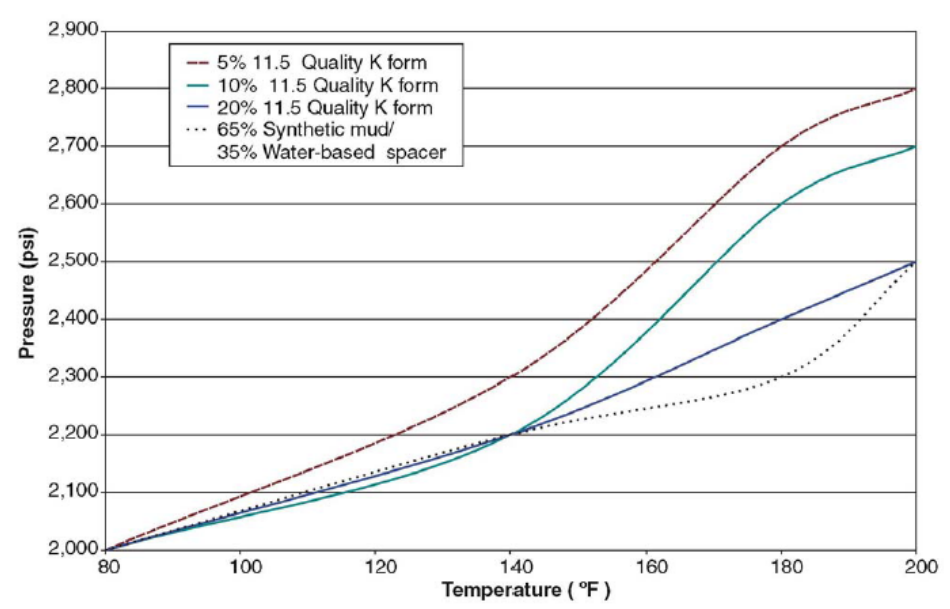

Figura 2.3: Comparação do crescimento de pressão para fluidos espumados (10).

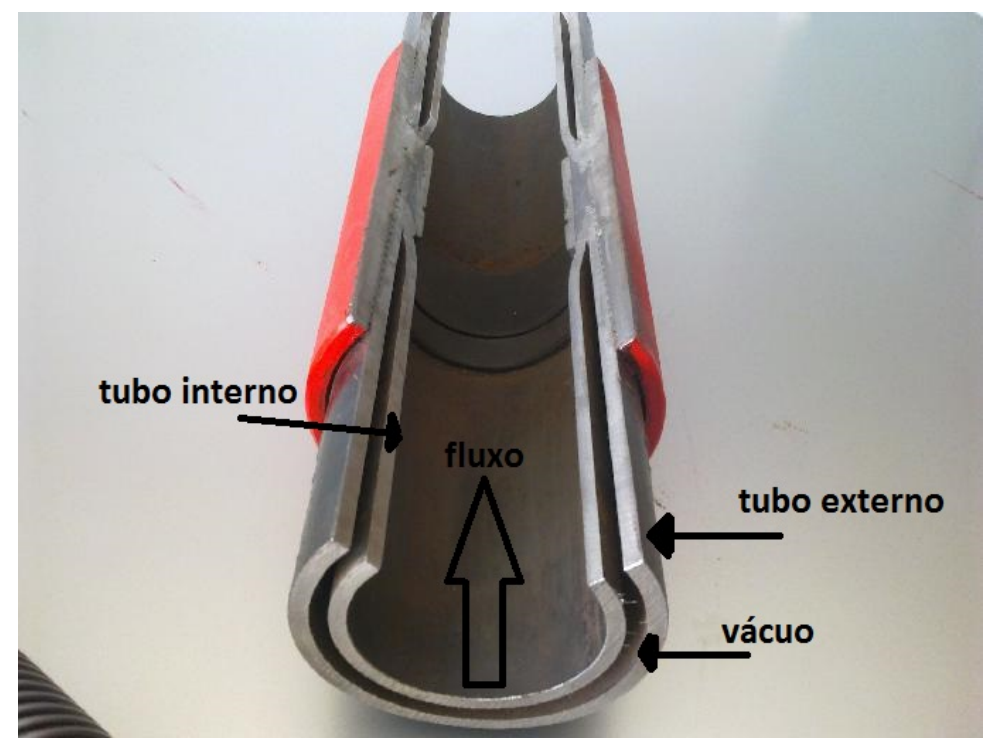

Figura 2.4: Esquema de um VIT.

\subsection{2}

\section{Modelagem matemática de APB}

Considerando o espaço anular completamente preenchido com fluido, o seu aquecimento levará a uma expansão volumétrica de acordo com o coeficiente de expansão térmica. A expansão será impedida pela parede do revestimento ou formação, gerando acréscimo de pressão. Essa pressão induzirá deformação das paredes e um equilíbrio será atingido (23).

De acordo com a equação de estado, a pressão do fluido depende da massa $(m)$, volume do espaço anular $\left(V_{a n}\right)$ e temperatura $(11)$.

$$
P=f\left(m, V_{a n}, T\right)
$$

Para pequenas variações de pressão é possível linearizar a equação 2-1: 


$$
\Delta P=\left(\frac{\partial P}{\partial m}\right)_{V_{a n}, T} . \Delta m+\left(\frac{\partial P}{\partial V_{a n}}\right)_{m, T} . \Delta V_{a n}+\left(\frac{\partial P}{\partial T}\right)_{m, V_{a n}} . \Delta T
$$

O primeiro termo da equação 2-2 relaciona a variação de pressão com a variação de massa no anular. Este vazamento de massa pode ocorrer para o interior das formações (fraturas ou poros) ou para anulares adjacentes (p. ex furo em revestimento). Para um anular perfeitamente selado este termo não gera contribuição alguma para o fenômeno de APB.

O segundo termo relaciona a variação de pressão com a variação volumétrica do anular. A coluna de revestimento e a rocha formam a fronteira do espaço anular. Estes sofrem deformações provenientes de esforços térmicos e hidráulicos devido ao aumento de temperatura e pressão respectivamente. No casos de poços do Pré-Sal a deformação por fluência do sal é outro mecanismo de alteração do volume anular. Em geral, esta parcela é responsável por 10\% a $20 \%$ da variação de pressão total do fenômeno de APB (24).

O último termo relaciona a variação de pressão devido ao aumento de temperatura a volume constante. Este termo pode ser reescrito da seguinte forma:

$$
\left(\frac{\partial P}{\partial T}\right)_{V_{a n}, m} . \Delta T=\left(\frac{\partial P}{\partial V_{a n}}\right)_{m, T} \cdot\left(\frac{\partial V_{a n}}{\partial T}\right)_{m, P} . \Delta T=\frac{C_{T}}{C_{P}} \cdot \Delta T
$$

Onde $C_{T}$ e $C_{P}$ denotam os coeficientes de expansão térmica e compressibilidade respectivamente. Geralmente os valores de $C_{T}$ e $C_{P}$ não são conhecidos para os fluidos de perfuração/completação, a menos de pequenos grupos de fluidos testados em laboratório com uma composição específica. Na maioria das vezes tais coeficientes são aproximados para os valores do fluido base (água ou óleo) (24).

Logo para um anular completamente selado temos:

$$
\Delta P=\frac{C_{T}}{C_{P}} \cdot \Delta T-\frac{1}{V_{a n} C_{P}} \cdot \Delta V_{a n}
$$

A deformação da fronteira e consequente aumento do volume do anular age como redutor da pressão final, acomodando parte da expansão volumétrica do fluido do anular. A figura ilustra 2.5 ilustra a diferença entre uma expansão térmica de um anular perfeitamente rígido e outro elástico. 


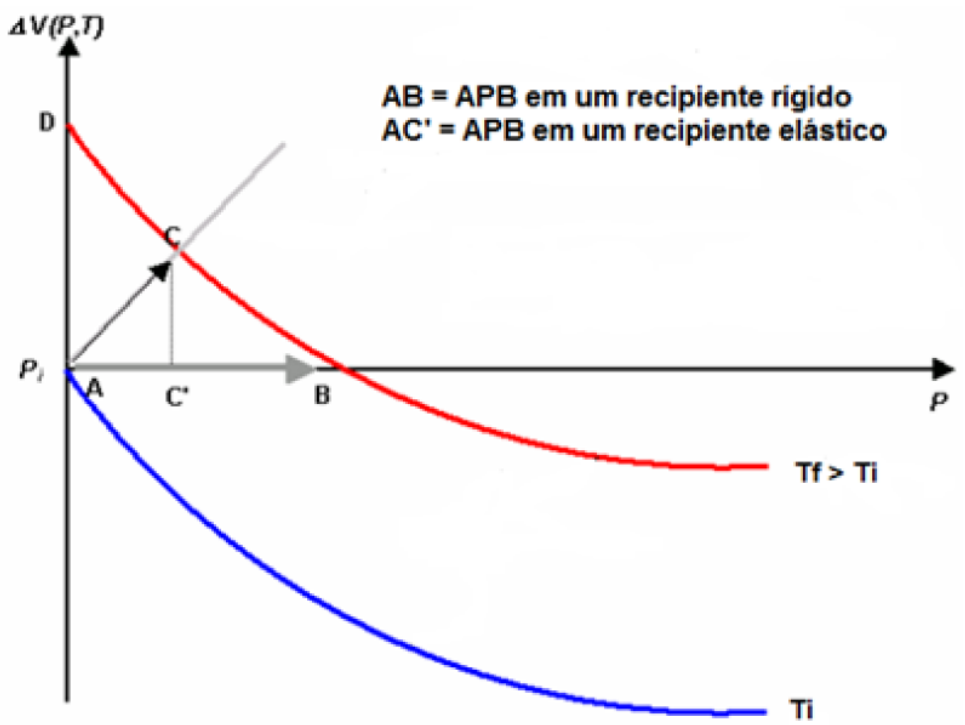

Figura 2.5: Crescimento de pressão em um recipiente elástico (18).

\section{2}

\section{Evaporitos}

Rochas salinas, também conhecidas como evaporitos, são rochas sedimentares formadas pela precipitação de sais contidos em meio aquoso. No contexto da indústria do petróleo, são associadas a grandes reservas de petróleo por serem boas estruturas capeadoras (25).

Uma rocha capeadora eficiente deve impedir a migração do óleo ou gás e se manter íntegra após sofrer grandes esforços e deformações resultantes dessa resistência à migração (figura 2.6). O sal é um material de porosidade nula e grande plasticidade, o que o torna uma rocha capeadora excelente. Cerca de $70 \%$ dos reservatórios carbonáticos de grandes campos de petróleo, como os do Pré-Sal, estão associados a depósitos de rochas salinas (26).

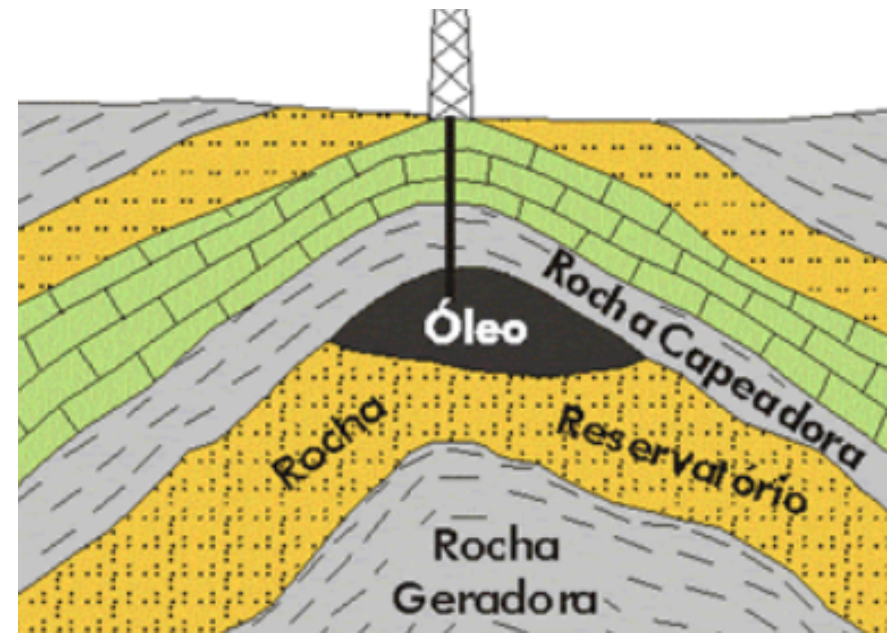

Figura 2.6: Geração de óleo e gás aprisionado por formação capeadora. 
Evaporitos são rochas solúveis e extremamente móveis, possuindo características de fluido e sólido. Essa movimentação ocorre quimicamente em meio aquoso (dissolução) ou fisicamente através de fluxo sólido. São consideradas rochas temporárias ou móveis, pois vieram de líquidos e retornam a este estado assim que possível.

As características peculiares das rochas salinas são benéficas no sentido de proporcionar um ambiente propício a acumulação de grandes reservas de petróleo e no aumento da assertividade da campanha de perfuração. Porém à essas características estão associados desafios para a sua perfuração e construção do poço (27).

Um dos problemas encontrados está relacionado a uma das propriedades do sal que, mesmo submetido a uma tensão constante, tende a se deformar ao longo do tempo, fenômeno conhecido como fluência ou creep. Este fenômeno pode acarretar no fechamento das paredes do poço. O gráfico da figura 2.7 apresenta um exemplo de fechamento radial de um poço, obtido através de simulação numérica (27). Como pode ser observado para este caso específico, o fechamento do poço acarretaria problemas operacionais a partir do momento no qual o deslocamento radial seja superior ao drift mínimo necessário para prosseguimento das operações.

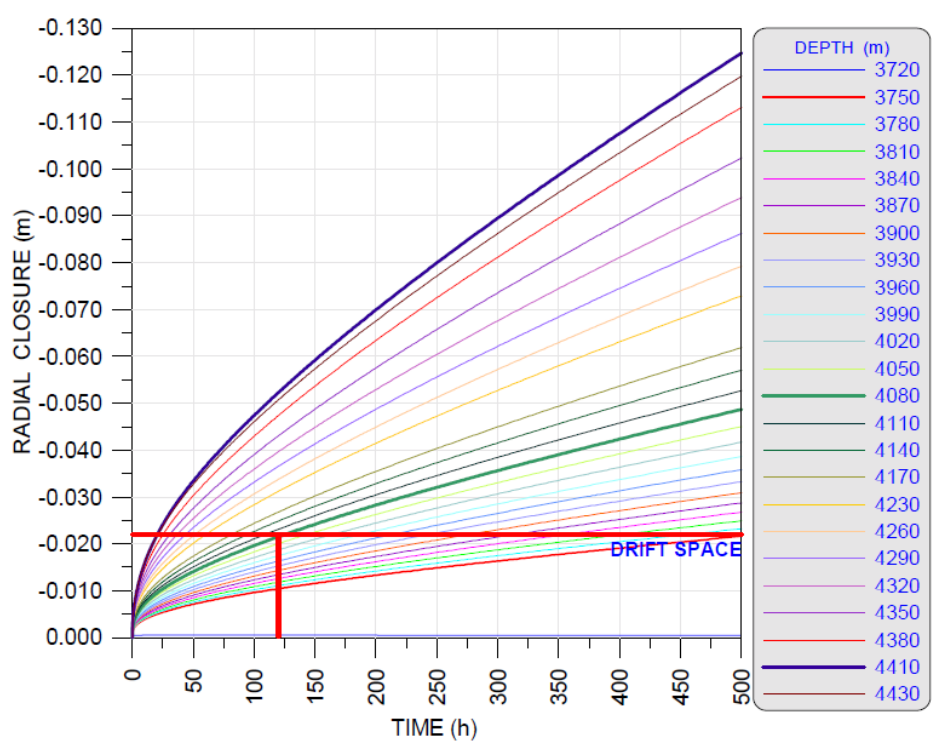

Figura 2.7: Simulação numérica do fechamento radial de um poço com presença de rocha salina (27).

Este fechamento das paredes do poço pode acarretar prisão da coluna de perfuração. Além disso, o contato da rocha salina com o revestimento gera esforços crescentes ao longo da vida útil do poço, que podem levar ao colapso do tubo $(28,29,30)$. 


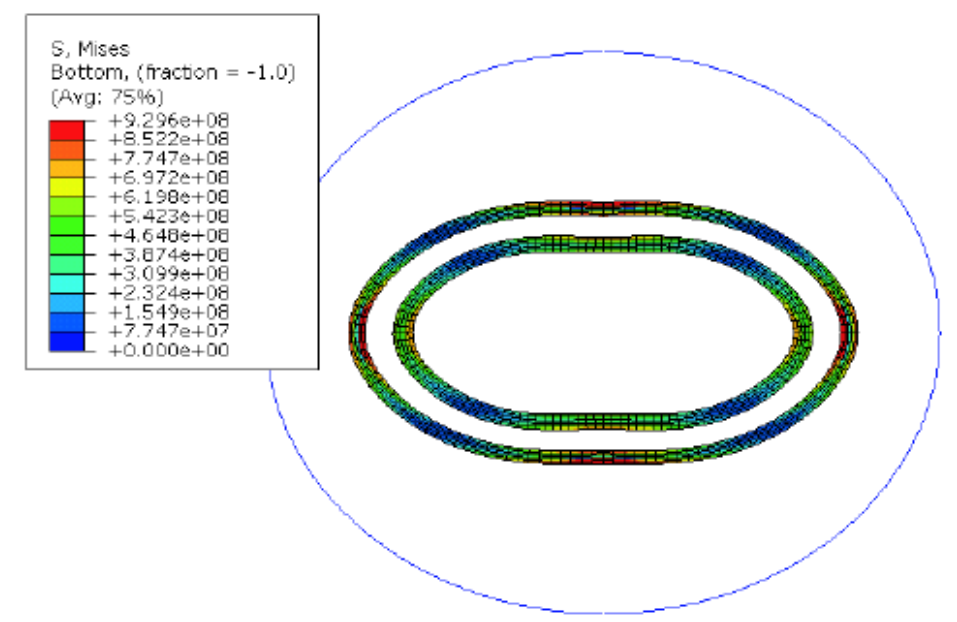

Figura 2.8: Aumento das tensões de von Mises da coluna de revestimento levando ao colapso do mesmo (28).

Há ainda outros problemas na perfuração de camadas salinas como o alargamento da parede do poço devido ao processo de dissolução do sal e perda de resistência por lixiviação.

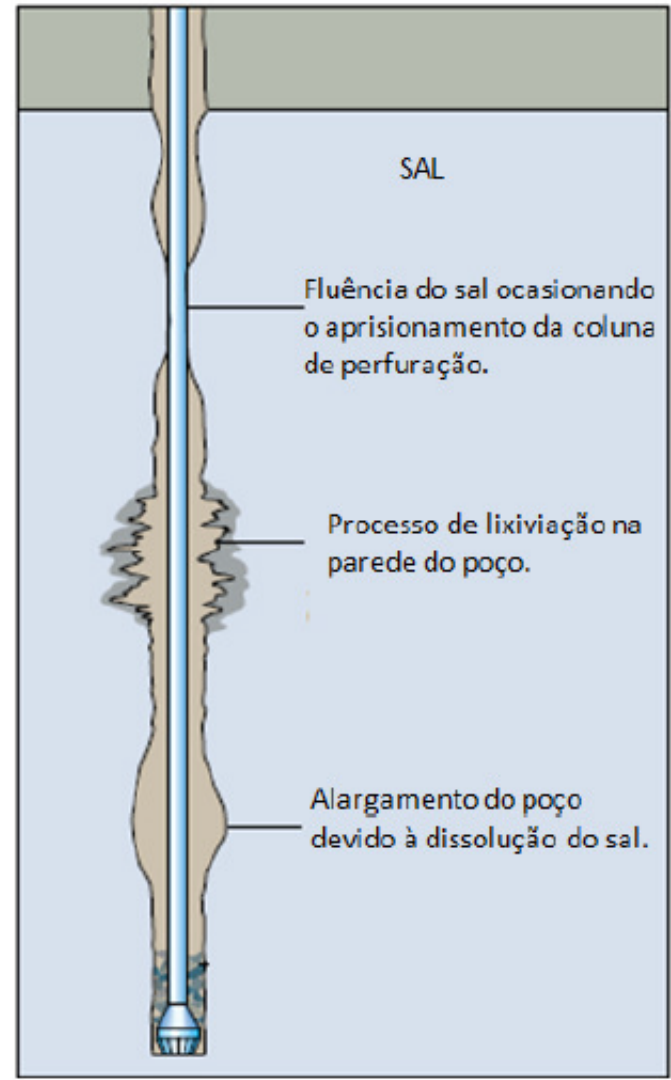

Figura 2.9: Ocorrências durante a perfuração de rocha salina.

Nas bacias brasileiras, as rochas evaporíticas mais comumente encontradas são a halita, silvinita, carnalita, taquidrita e anidrita. No entanto, nem 
todas apresentam mobilidade (fluência) relevante, como é o caso da anidrita. Nas colunas litológicas de sal dos poços do Brasil, a halita é o evaporito predominante, que em geral é referenciada nas publicações e na indústria do petróleo como apenas "sal"(31).

\subsection{1}

\section{Fluência de evaporitos}

O fenômeno de fluência é conhecido desde o século passado e foi inicialmente reportado por Vicat em 1834 (32). Seu estudo teve como base os metais, para os quais os primeiros modelos foram criados a fim de caracterizar este comportamento.

A fluência é caracterizada por um acúmulo paulatino de deformações inelásticas, que em geral não apresentam dependência apenas da carga, mas também da temperatura e do tempo .

$$
\epsilon=f(\sigma, T, t)
$$

No caso dos evaporitos, a deformação pode ainda apresentar dependência com a espessura da camada de sal, composição mineralógica, teor de água e presença de impurezas. $(33,34)$.

Thurston em 1895 foi o primeiro a descrever os três estágios da curva $\epsilon \times t$ (35). Para a aplicação de uma tensão e temperatura constantes, a evolução da deformação segue o gráfico da figura 2.10, também conhecido como curva de Andrade (32).

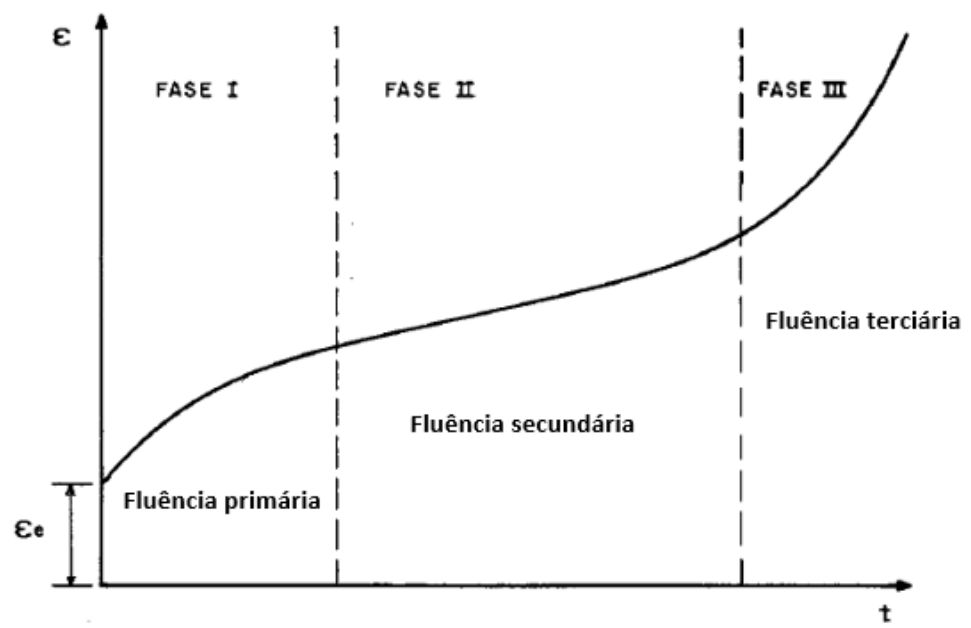

Figura 2.10: Estágios da curva de deformação por fluência.

As três fases são: 
- Fase 1 ou Fluência primária: Nessa etapa temos inicialmente uma deformação elástica instantânea $\epsilon_{e}$. Em seguida tem início a fluência primária, que em geral dura um curto intervalo de tempo e é caracterizada por uma taxa de fluência $\dot{\epsilon}$ decrescente com o tempo. Neste estágio, caso a tensão aplicada seja retirada, ocorre a recuperação elástica instantânea e em seguida a lenta recuperação da deformação de fluência. Ao final do processo não restam deformações permanentes.

- Fase 2 ou Fluência secundária: A partir do término da fase I temos o começo da fluência secundária, que representa maior parte do processo como um todo. Esta fase possui como característica principal uma taxa de deformação constante. Caso a tensão aplicada seja retirada, há uma instantânea recuperação da deformação elástica e em seguida uma recuperação lenta com o tempo, assim como na fase I. No entanto, ao final do processo resta uma deformação permanente.

- Fase 3 ou Fluência terciária: É a fase final, onde a taxa de deformação $\dot{\epsilon}$ aumenta com o tempo até uma eventual ruptura do material. Neste estágio o material sofre dilatação, com aumento de volume através do desenvolvimento de micro fraturas que levam a falha do material (21).

O gráfico da figura 2.11 apresenta o comportamento das taxas de deformação ao longo das três fases de fluência, conforme dito acima.

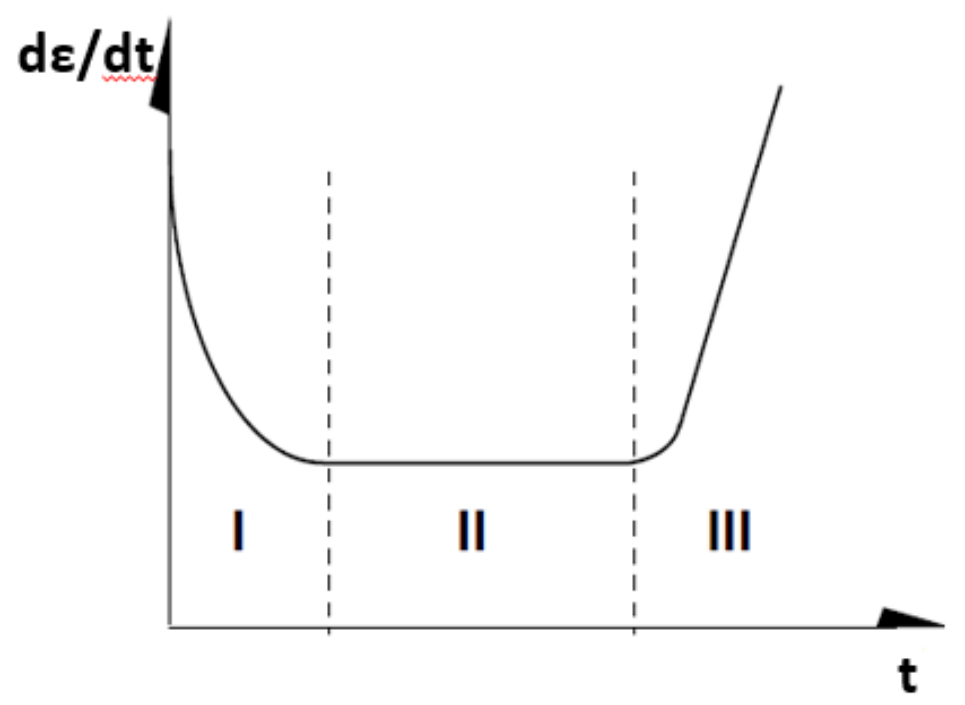

Figura 2.11: Taxa de deformação ao longo das fases de fluência do material. 


\subsection{2}

\section{Comportamento dos evaporitos}

Conforme discutido na seção 2.1, o aquecimento gerado pela produção de hidrocarbonetos em alta temperatura é um mecanismo de aumento de pressão dos anulares confinados.

Em poços do Pré-Sal, ou de forma geral, que possuam formações evaporíticas, se tem outro mecanismo de alteração de pressão anular, devido à variação volumétrica sofrida ao longo do tempo pela fluência da rocha salina $(20,21)$.

A deformação por fluência da rocha salina reduz o diâmetro do poço e consequentemente o volume anular, que então comprime o fluido de perfuração e aumenta a pressão anular. Simulações numéricas quantificaram a pressurização do anular devido à presença do sal (20). Devido a natureza incompressível do fluido de perfuração, uma pequena variação volumétrica pode acarretar em altos acréscimos de pressão (22). Para o caso simulado em (20), em 10 anos de fechamento de poço a pressão aumentou aproximadamente $10 \mathrm{MPa}$. O gráfico da figura 2.12 mostra a evolução no tempo do acréscimo de pressão gerado pelo fechamento das paredes do poço (figura 2.13), para fluidos de perfuração com diferentes compressibilidades (20).

\section{Annular pressure build-up}

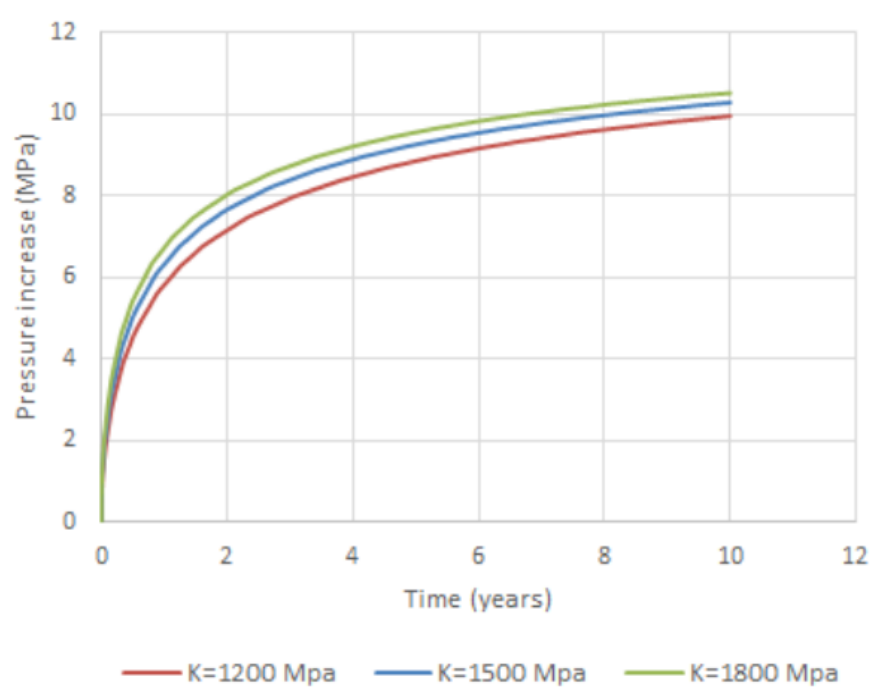

Figura 2.12: APB devido à fluência do sal (20). 


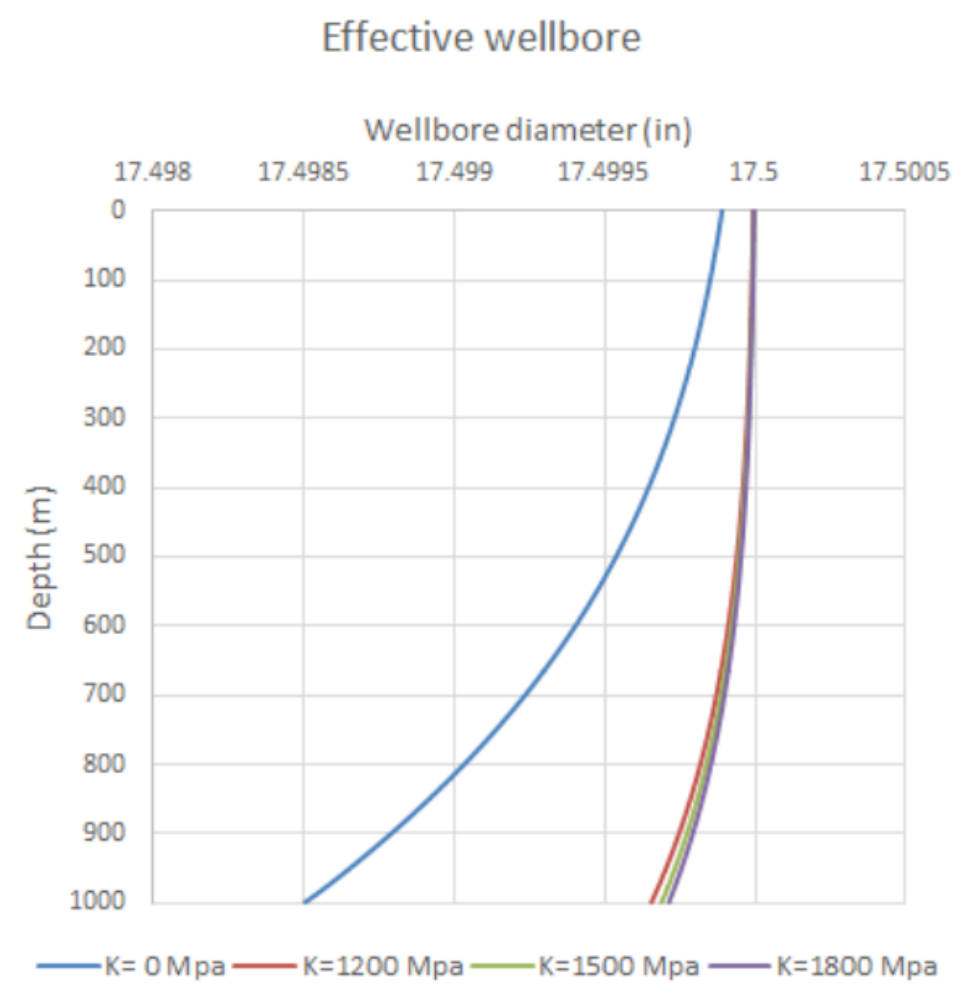

Figura 2.13: Redução do diâmetro do poço devido à fluência do sal (20).

No caso do cálculo tradicional do fenômeno de APB devido à produção do poço, não considerar o efeito da fluência do sal pode levar a um inadequado dimensionamento dos revestimentos e equipamentos do poço. Simulações realizadas para o cálculo do APB devido ao efeito térmico, acoplado com o APB gerado pelo sal, resultaram em acréscimos de pressão até $60 \%$ superiores ao APB puramente térmico (21).

No entanto, a depender da combinação de parâmetros do poço, como tipo de sal, temperatura e estado de tensão, o sal pode agir como aliviador da pressão, através do acréscimo do volume anular pela fluência no sentido de aumento do diâmetro do poço (figura 2.14). 


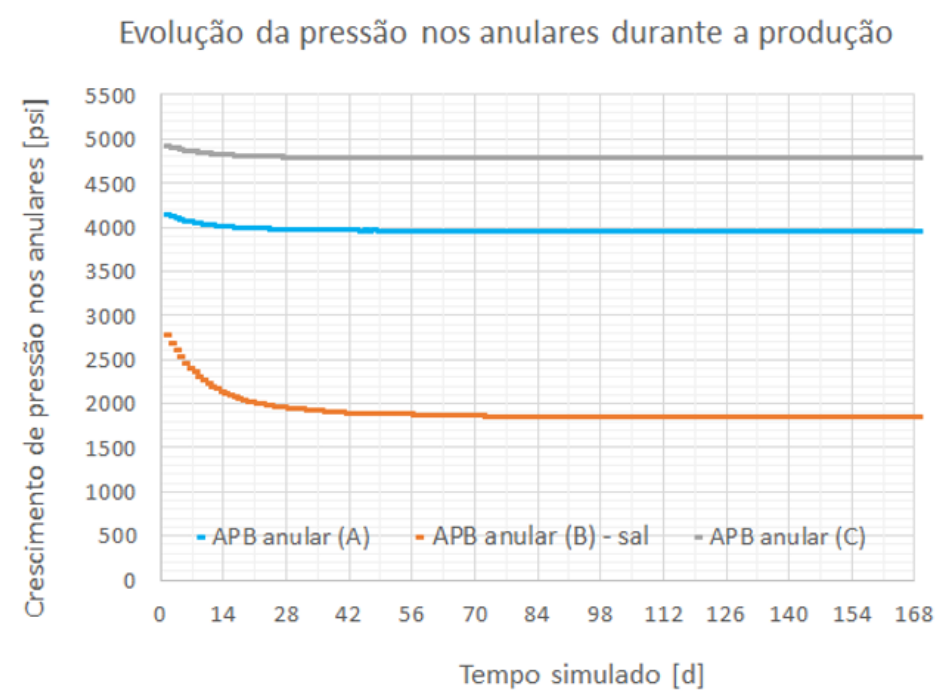

Figura 2.14: Alívio de pressão devido à fluência do sal (21).

\subsection{3}

\section{Modelo constitutivo}

A partir da evolução do conhecimento sobre o fenômeno de fluência, que teve início com os materiais metálicos, diversos modelos foram criados a fim de descrever e quantificar as deformações de fluência ao longo do tempo. Os experimentos de laboratório para levantamento de dados, são em geral demorados e potencialmente custosos financeiramente. Com isso, os modelos matemáticos muitas vezes são utilizados para se fazer extrapolações de comportamento para combinações de tensões, temperatura e tempo diferentes das ensaiadas. Os modelos criados podem ser divididos em três grandes grupos: físicos, empíricos e reológicos (36).

Os modelos empíricos basicamente são funções matemáticas ajustadas a partir de dados observados ou retirados de ensaios realizados. Nestes casos, a lei de fluência recebe a nomenclatura do tipo de função matemática utilizada para representar os dados, podendo ser do tipo potencial, logarítmica ou exponencial, sendo a primeira denominação a mais comum e que melhor se ajusta ao período primário de fluência (36).

Os modelos reológicos representam o comportamento do material de forma macroscópica, através de elementos básicos da física como molas e amortecedores, a fim de reproduzir os comportamentos elástico, plástico e viscoso de um material. Esses componentes elementares (mola e amortecedor) podem ser combinados de diversas maneiras com o objetivo de criar modelos constitutivos de diferentes níveis de complexidade e que se adequem melhor a um determinado material específico. Nesse grupo podem ser citados, por exemplo, os modelos de Maxwell, Burguers, Kelvin e outros. 
Com a evolução do conhecimento do fenômeno de fluência para evaporitos, foram desenvolvidos os modelos físicos. Além de variáveis como tensão, temperatura, módulo de cisalhamento e taxa de deformação, considerados nos modelos descritos anteriormente, é considerado o efeito da microestrutura do material.

Segundo Munson (37), foram identificados cinco mecanismos de deformação secundária, sendo eles: defect-less, dislocation slip, dislocation climb, diffusional creep e undefined mechanism. A contribuição de cada mecanismo em particular é definida pela temperatura e nível de tensão desviatória.

O gráfico da figura 2.15 apresenta o mapa definido por Munson, no qual o eixo horizontal $T / T_{m}$ representa a temperatura normalizada pela temperatura de fusão e o eixo vertical a tensão normalizada pelo módulo de cisalhamento $\mu$.

Para altos níveis de tensão a fluência secundária está associada a superposição de diversos mecanismos de deslizamento, combinados com um fator de ativação térmica.

Em altas temperaturas, a oscilação dos átomos do material promove a redistribuição molecular da estrutura, que provoca o aumento da taxa de fluência.

O mecanismo indefinido recebe esta nomenclatura por não estar associado a nenhum efeito micro mecânico. Este mecanismo se situa em configurações de baixa temperatura e baixo nível de tensão.

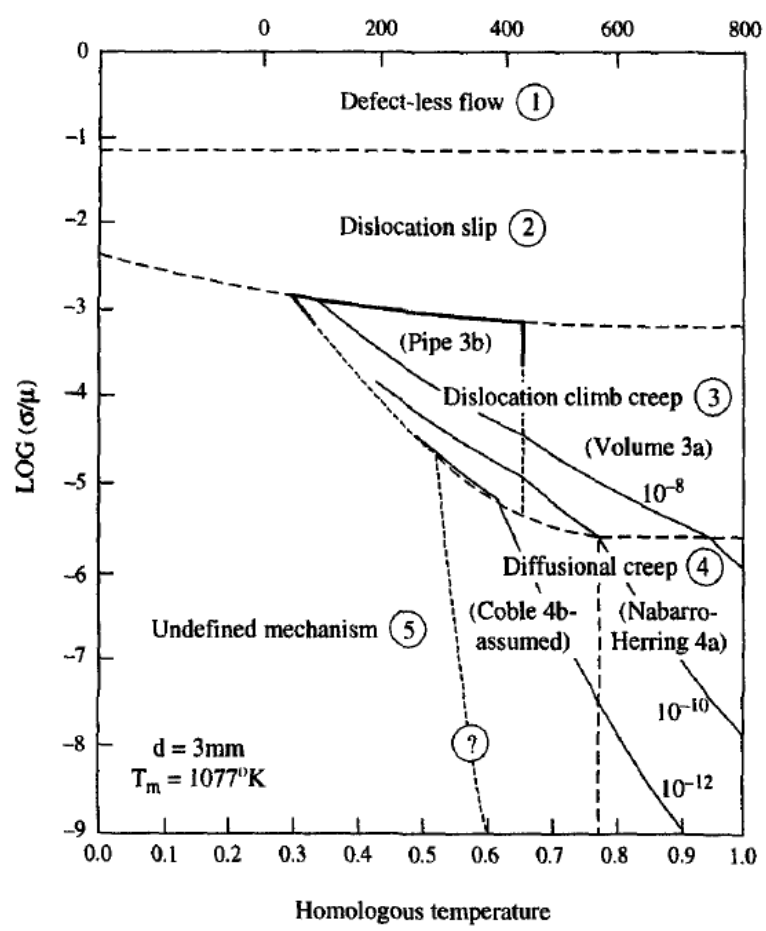

Figura 2.15: Mapa de mecanismos de deformação secundária (37). 
Para a modelagem do comportamento viscoelástico do sal, a indústria do petróleo utiliza o modelo de duplo mecanismo $(38,25)$, que corresponde a uma simplificação na lei desenvolvida por Munson e que considera os mecanismos dislocation glide e indefinido. Este modelo será o utilizado no desenvolvimento deste trabalho. A equação 2-6 apresenta o modelo de duplo mecanismo.

$$
\dot{\epsilon}= \begin{cases}\dot{\epsilon_{0}} \cdot\left(\frac{\sigma_{e f}}{\sigma_{0}}\right)^{n_{1}} \cdot e^{\left(\frac{Q}{R T_{0}}-\frac{Q}{R T}\right)} & \text { se } \sigma_{e f}<\sigma_{0} \\ \dot{\epsilon_{0}} \cdot\left(\frac{\sigma_{e f}}{\sigma_{0}}\right)^{n_{2}} \cdot e^{\left(\frac{Q}{R T_{0}}-\frac{Q}{R T}\right)} & \text { se } \sigma_{e f}>\sigma_{0}\end{cases}
$$

Onde:

- $\dot{\epsilon}$ : Taxa de deformação de fluência em regime estacionário (fase II).

- $\dot{\epsilon_{0}}$ : Taxa de deformação de referência.

- $\sigma_{e f}$ : Tensão efetiva de fluência.

- $\sigma_{0}$ : Tensão efetiva de referência.

$-T_{0}$ : Temperatura de referência.

- $n$ : Expoente que depende do nível de tensão.

- $Q$ : Energia de ativação.

- $R$ : Constante universal dos gases.

A taxa de deformação por fluência de referência em regime permanente $\dot{\epsilon_{0}}$ é obtida em um ensaio de laboratório realizado em uma temperatura de referência $T_{0}$ e tensão desviatória $\sigma_{0}$.

No caso do modelo de duplo mecanismo, a tensão desviatória ou efetiva de fluência, é determinada através da aplicação do critério de von Mises, conforme equação 2-7.

$$
\sigma_{e f}=\sqrt{\frac{\left(\sigma_{x}-\sigma_{y}\right)^{2}+\left(\sigma_{x}-\sigma_{z}\right)^{2}+\left(\sigma_{y}-\sigma_{z}\right)^{2}+6\left(\tau_{x y}^{2}+\tau_{x z}^{2}+\tau_{y z}^{2}\right)}{2}}
$$

O expoente n é obtido através da realização de diversos ensaios de fluência com diferentes níveis de tensão desviatória $\sigma_{e f}$. A tensão de referência $\sigma_{0}$ marca o limite no qual ocorre a transição de mecanismo e o valor do expoente muda de $n_{1}$ para $n_{2}$. Este ponto é representando pela interseção das duas retas ajustadas ao gráfico em escala logarítmica, para os pares $\log (\epsilon) \times \log \left(\sigma_{e f}\right)$. O gráfico da figura 2.16 apresenta os resultados obtidos em um ensaio de laboratório para a determinação dos parâmetros utilizados no modelo de duplo mecanismo (33). 


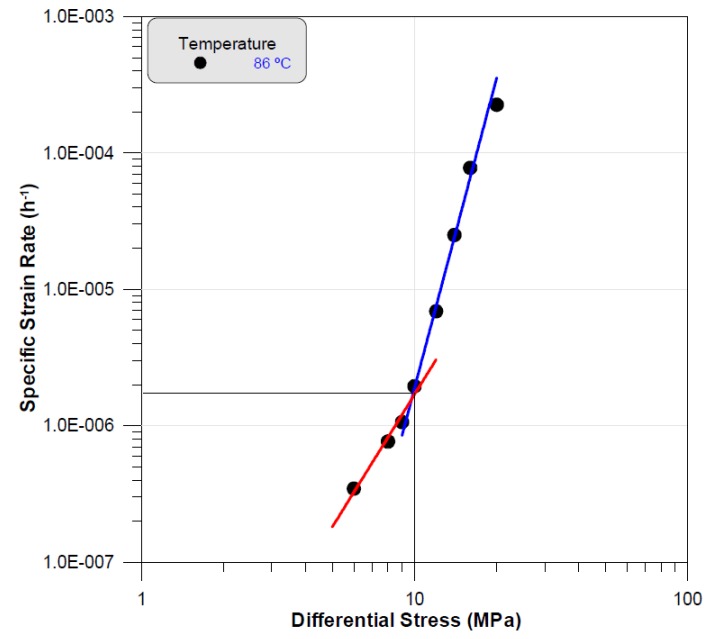

Figura 2.16: Taxas de deformação em regime permanente (33). 


\section{3 \\ Modelo numérico}

Para o cálculo do fenômeno de APB foi construído um modelo termo mecânico axissimétrico em elementos finitos utilizando as funcionalidades do software comercial ABAQUS (40). Este programa possibilita a modelagem de processos complexos envolvendo geometrias diversas, relações constitutivas especiais, como por exemplo a fluência (sal, neste caso), processos transientes e grandes deformações. Todo o processo desde a criação do modelo (pré processamento), resolução do problema (solver) e pós processamento foi realizado dentro do ABAQUS.

O modelo numérico desenvolvido neste trabalho tem por objetivo simular o fenômeno de APB acoplado ao processo de fluência da rocha salina. As etapas anteriores ao início da produção do poço e início do aquecimento que gera o APB também são simuladas. A construção do poço, que engloba as fases de perfuração e descida da coluna de revestimento, estão incorporadas ao modelo de modo representar o estado de tensões e deformações a que o poço está submetido no início da fase de produção.

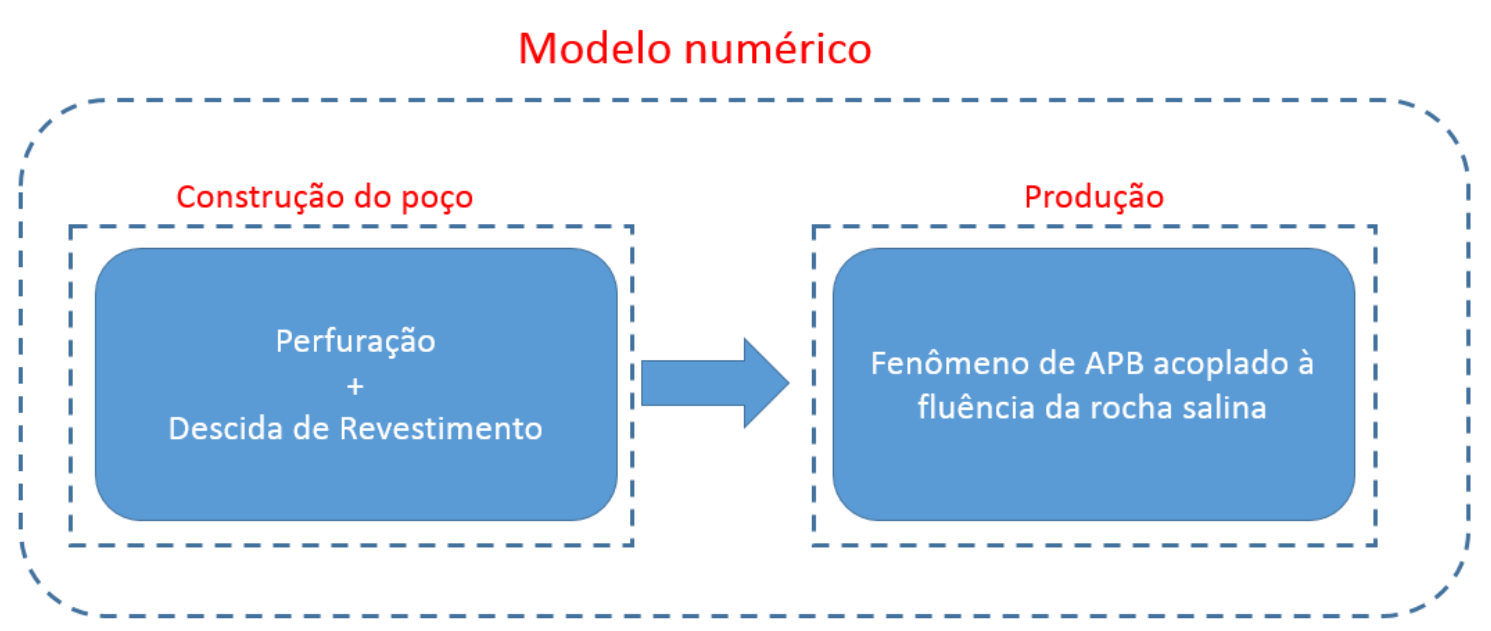

Figura 3.1: Modelo numérico englobando a construção e produção do poço de petróleo. 


\section{1}

\section{Geração do modelo}

A geração do modelo de elementos finitos é realizada de forma automatizada através de um código desenvolvido na linguagem de programação Python. O software ABAQUS possui uma interface de desenvolvimento de scripts que possibilita a criação do arquivo CAE (Complete ABAQUS Environment), sem a utilização da interface gráfica.

Todos os parâmetros necessários para a geração do modelo são disponibilizados via arquivo texto ao código Python, responsável pela construção do modelo. O fluxograma da figura 3.2 ilustra o processo de geração do modelo.

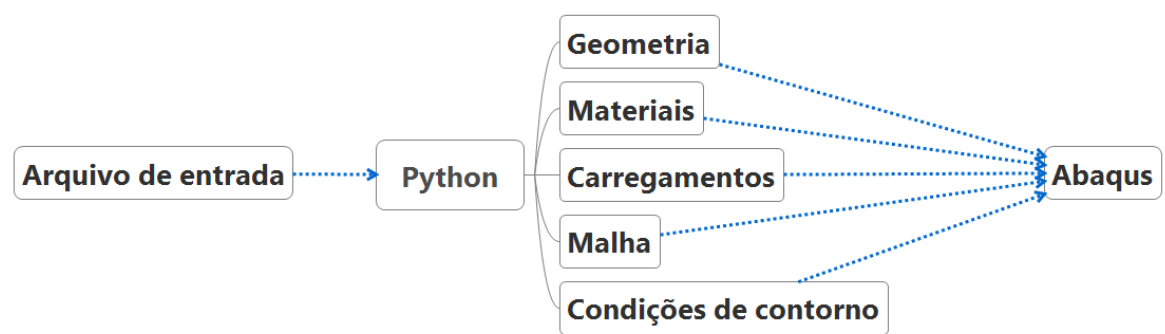

Figura 3.2: Fluxograma de construção do arquivo de simulação no ABAQUS.

O desenvolvimento de um modelo complexo através da interface gráfica do ABAQUS é um processo lento que demanda tempo e que se limita a simular apenas o cenário específico para o qual foi construído. A automatização do processo de criação do modelo torna o processo mais ágil, no sentido de que diferentes casos de simulação podem ser rapidamente desenvolvidos.

\section{2}

\section{Geometria}

Para analisar o fenômeno de crescimento de pressão em anulares confinados (APB), se gera uma geometria padrão que representa um poço fictício do Pré-Sal. Este modelo serve de base para os diferentes tipos de simulação com diferentes conjuntos de parâmetros a serem investigados. A figura 3.3 ilustra a configuração escolhida. 


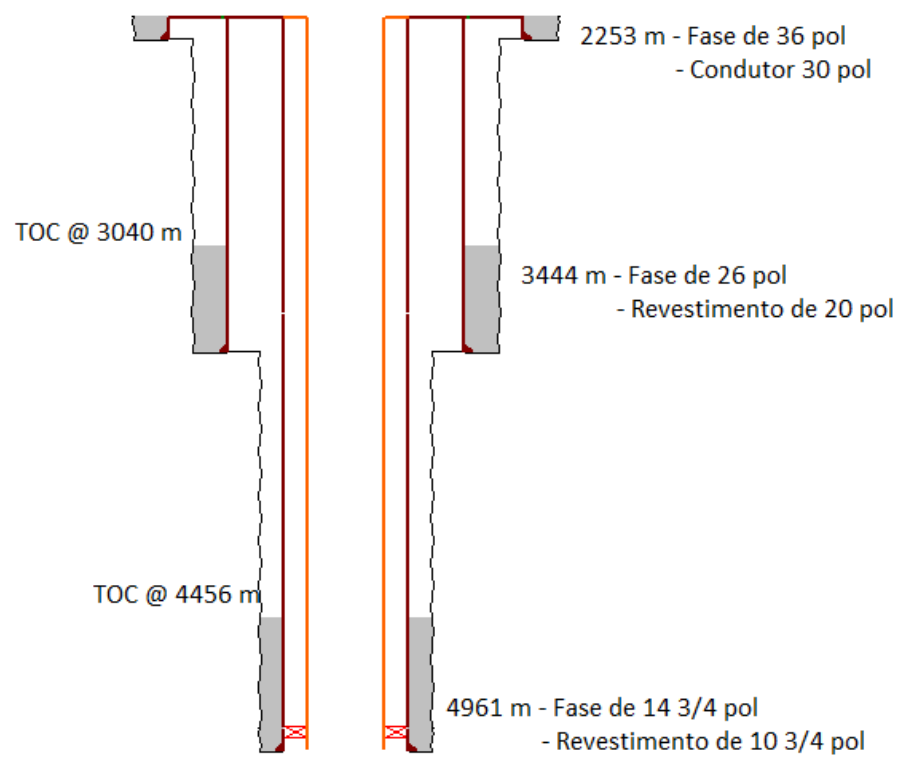

Figura 3.3: Geometria padrão que representa um poço fictício do Pré-Sal.

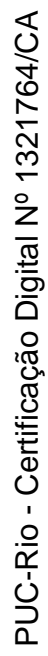

Essa configuração de poço apresentada possui apenas até a terceira fase (intermediária), que é a fase que possui a formação salina. A fase de produção não foi incluída no modelo para diminuir seu tamanho e reduzir o custo/tempo de processamento. A tabela 3.1 contém os parâmetros utilizados.

Tabela 3.1: Parâmetros geométricos do poço padrão.

\begin{tabular}{|l|c|c|c|}
\hline & Fase 1 & Fase 2 & Fase 3 \\
\hline Diâmetro do poço (pol) & 36 & 26 & 14.75 \\
\hline Profundidade de topo (m) & 2169 & 2253 & 3444 \\
\hline Profundidade da base (m) & 2253 & 3444 & 4961 \\
\hline Diâmetro externo do revestimento (pol) & 30 & 20 & 10.75 \\
\hline Espessura do revestimento (pol) & 1.5 & 1 & 0.797 \\
\hline Profundidade de topo do cimento (m) & 2169 & 3040 & 4456 \\
\hline
\end{tabular}




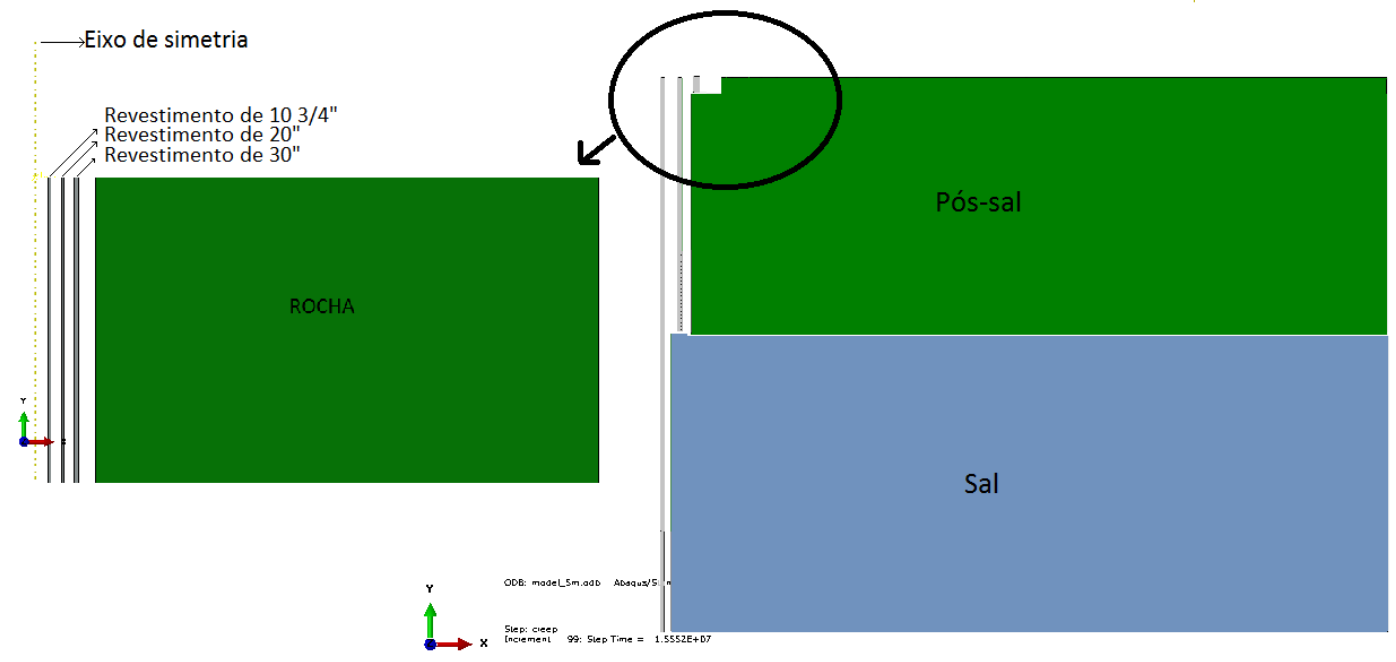

Figura 3.4: Vista axissimétrica da geometria do modelo, com destaque para os revestimentos utilizados.

Ao longo do trabalho os anulares do poço são referenciados pelas letras A, B e C, sendo A o mais interno e C o mais externo, conforme ilustra a figura 3.5. O anular A é o que contém o trecho salino e é o foco das análises a serem realizadas. O anular $\mathrm{C}$ foi considerado totalmente cimentado e não será analisado no presente trabalho.

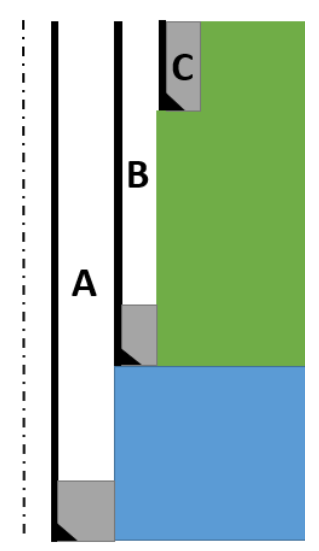

Figura 3.5: Esquema da nomenclatura dos anulares.

\subsection{1}

\section{Borda do modelo}

A borda externa do modelo possui um raio de 5 metros. Este tamanho foi determinado através de uma relação de compromisso entre o tempo de simulação e efeitos de borda. Quanto maior o tamanho do modelo, maior será 
o custo computacional. No entanto, a fronteira deve ter tamanho suficiente para não influenciar no resultado.

A fim de determinar o menor tamanho possível do modelo que proporcionasse uma resposta sem interferência da fronteira, foram criadas duas simulações de um poço padrão, com um tamanho de 15 metros e 5 metros na direção radial e analisado o campo de tensões resultante.

O ponto de controle para investigação do estado de tensões foi a profundidade de 4960 metros, visto que o diferencial de tensão tende a aumentar com a profundidade e consequentemente o nível de deformações elásticas e de fluência. Foi utilizado um peso de fluido de 11.5 ppg para simular a perfuração desta fase do poço, o que representa uma tensão de -67 MPa nesta profundidade. A tensão vertical é de -78 MPa e a formação salina está sujeita a um estado de tensão inicial hidrostático, ou seja, tensão de von Mises nula.

O gráfico da figura 3.6 ilustra o campo de tensões de von Mises na direção radial para a profundidade de 4960 metros, imediatamente após a perfuração do poço. Como se pode observar a tensão de von Mises tende ao seu valor original com boa aproximação após 5 metros e continua dessa forma até os 15 metros.

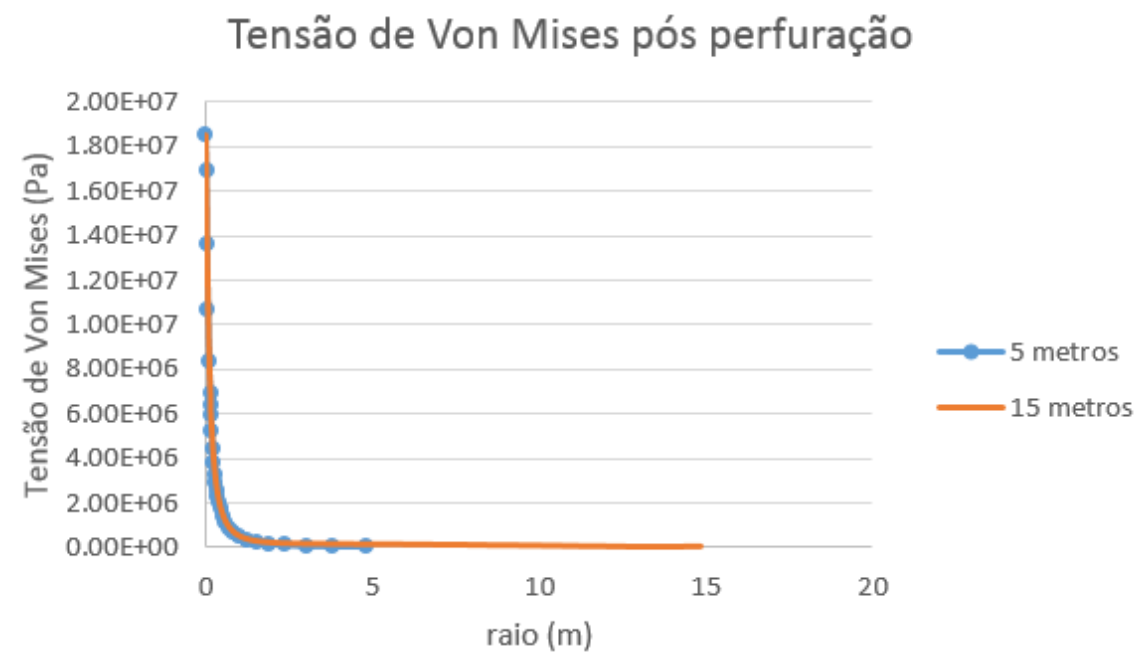

Figura 3.6: Tensão de von Mises ao longo da direção radial imediatamente após a perfuração do poço.

Adicionalmente foi simulada a fluência dos próximos 6 meses, de forma a analisar o comportamento da tensão de von Mises ao fim da simulação e verificar se há interferência da fluência do sal na borda do modelo. O tempo de 6 meses foi escolhido por englobar com folga o período de pressurização do anular devido ao fenômeno de APB. O gráfico da figura 3.7 ilustra a tensão de von Mises ao fim do período de simulação. Pode-se notar que após 6 meses 
a tensão de von Mises na borda do modelo ainda se encontra próxima a seu valor original.

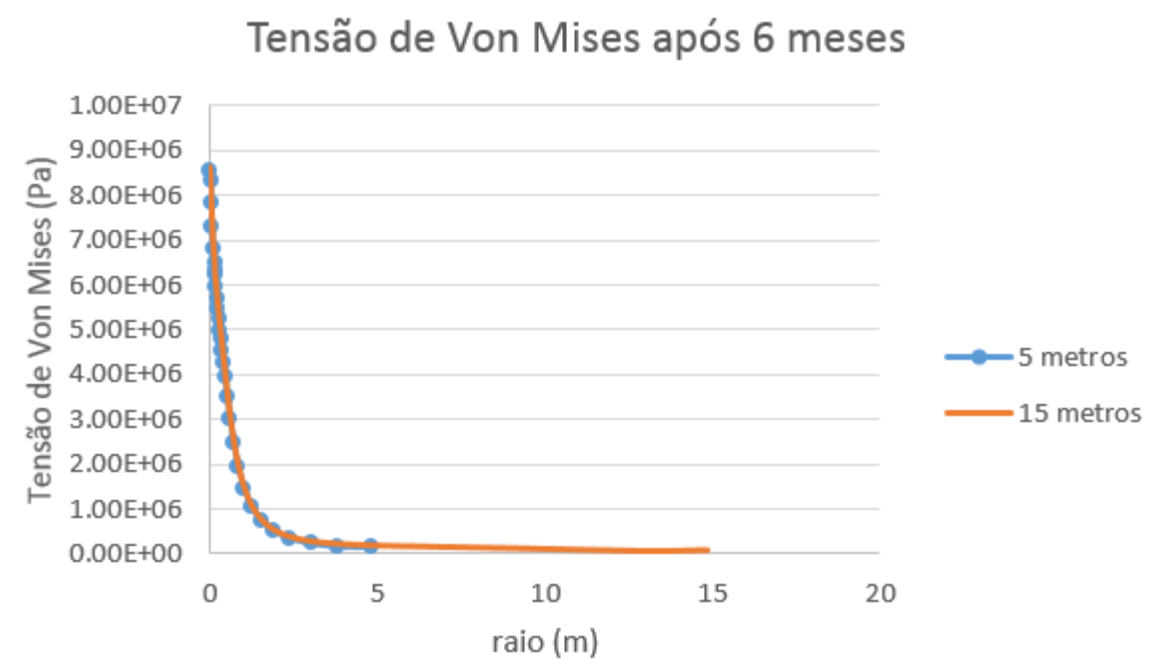

Figura 3.7: Tensão de von Mises ao longo da direção radial após 6 meses.

Dessa forma, foi escolhido um tamanho de 5 metros na direção radial para todas as simulações realizadas nesse trabalho. Com isso tem-se um balanço entre a precisão da resposta desejada e um tempo de simulação razoável. Nessa simulação simplificada, sem a inclusão do fenômeno de APB ou outros fatores que demandariam mais esforços computacionais, a diferença no tempo de simulação é da ordem de 2 vezes. A simulação de 5 metros chegou ao fim após 15 minutos e a de 15 metros em 30 minutos.

\section{3}

\section{Materiais utilizados}

Um poço de petróleo contém uma vasta gama de materiais, incluindo metais, rochas, elastômeros e fluidos. Dentro de cada classificação existem ainda diversas famílias de materiais. No entanto, no presente trabalho foi utilizado um conjunto restrito de materiais, para fins de simplificação de implementação do modelo numérico e por não ser o objetivo de estudo analisar a combinação/intercalação dos diferentes materiais.

\subsection{1}

\section{Litologia}

A coluna litológica de um poço é em geral bastante heterogênea, com as propriedades dos materiais variando ao longo da profundidade mesmo para um determinado tipo fixo de rocha. A figura 3.8 ilustra a variação litológica de um mesmo tipo de rocha em um poço de petróleo. Neste trabalho serão 
considerados determinados tipos de rochas com propriedades constantes ao longo da profundidade do poço.

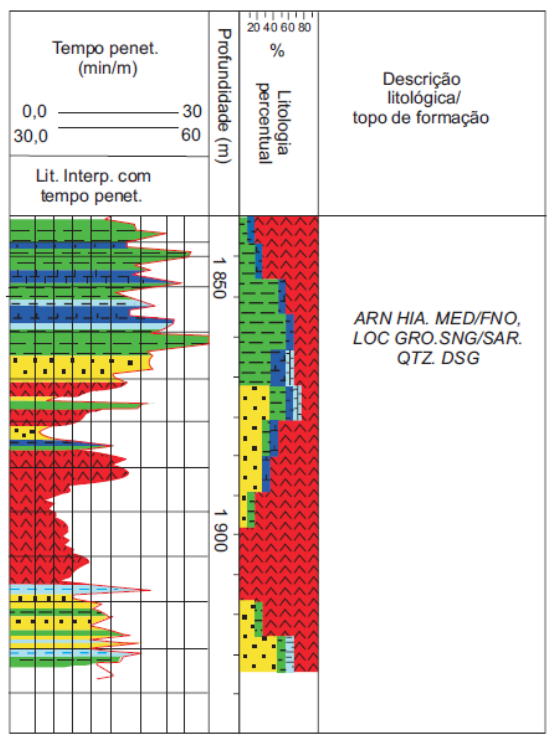

Figura 3.8: Trecho do perfil litológico de um poço de petróleo (39) .

O poço foi dividido em duas partes com relação a litologia empregada. A região do pós-sal, contendo a parte superior do poço que se estende do leito marinho até o topo do sal e a região salina.

A região do pós-sal foi considerada preenchida por um folhelho puro, sem intercalações de outros materiais. Tal material foi escolhido por ser o mais representativo da região do pós-sal. Para a construção do trecho salino foi utilizado halita e carnalita. A halita é a rocha predominante na coluna de sal e a carnalita foi utilizada para representar a presença de sal de alta mobilidade. A tabela 3.2 apresenta as propriedades mecânicas e térmicas utilizadas nas simulações para os diferentes tipos de rocha.

Tabela 3.2: Propriedades mecânicas das rochas utilizadas.

\begin{tabular}{|l|c|c|c|}
\hline & Folhelho & Halita & Carnalita \\
\hline Módulo de Young (GPa) & 7.5 & 20.4 & 4.2 \\
\hline Coeficiente de Poisson & 0.25 & 0.36 & 0.36 \\
\hline Densidade $\left.\mathbf{( k g} / \mathbf{m}^{3}\right)$ & 1900 & 2200 & 2200 \\
\hline
\end{tabular}

O modelo de fluência utilizado para as rochas salinas é o de duplo mecanismo. A tabela 3.3 apresenta as constantes de fluência do modelo de duplo mecanismo (eq.2-6). A temperatura de referência para ambos os tipos de sal é de $86^{\circ} \mathrm{C}$. 
Tabela 3.3: Constantes do modelo de fluência de duplo mecanismo.

\begin{tabular}{|l|l|c|l|l|}
\hline & $\dot{\epsilon_{0}}\left(\mathrm{~s}^{-1}\right)$ & $\sigma_{0}(\mathrm{MPa})$ & $n_{1}$ & $n_{2}$ \\
\hline Halita & $5.22 \times 10^{-10}$ & 9.92 & 3.36 & 7.55 \\
\hline Carnalita & $4.31 \times 10^{-8}$ & 5.71 & 2.87 & 7.17 \\
\hline
\end{tabular}

\subsubsection{1}

\section{Revestimentos}

O material utilizado para as colunas de revestimento do poço padrão é o mesmo para as três fases do poço. Foi utilizado um aço com as mesmas propriedades elásticas.

O peso linear do revestimento é uma propriedade usualmente utilizada para a especificação do revestimento. Uma vez que a espessura da parede e o diâmetro estejam definidos (tabela 3.1), a densidade do material, que é uma propriedade mais comum para especificação de um material, é automaticamente determinada. A equação 3-1 relaciona essas propriedades, onde:

$$
W=\rho \pi\left(e D-e^{2}\right) g
$$

- W: Peso linear.

- $\rho$ : Densidade.

- e: Espessura do revestimento.

- D: Diâmetro externo do revestimento.

- g: Aceleração da gravidade.

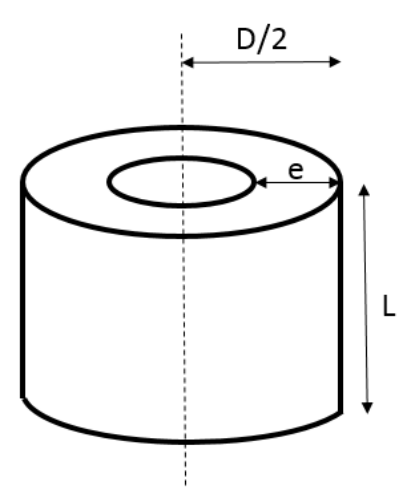

Figura 3.9: Esquema das dimensões de um tubo de revestimento.

A tabela a seguir apresenta os valores utilizados no presente modelo numérico: 
Tabela 3.4: Propriedades das colunas de revestimento.

\begin{tabular}{|l|c|c|c|c|}
\hline Revestimento & \multicolumn{4}{|c|}{ Propriedades } \\
\hline D (pol) & E (GPa) & $\nu$ & W (lbf $/ \mathbf{f t})$ & e (pol) \\
\hline 30 pol & 210 & 0.3 & 554 & 1.5 \\
\hline $\mathbf{2 0 ~ p o l ~}$ & 210 & 0.3 & 203 & 1.0 \\
\hline $\mathbf{1 0 . 7 5}$ pol & 210 & 0.3 & 85.3 & 0.8 \\
\hline
\end{tabular}

\subsubsection{2}

\section{Fluido de perfuração}

Geralmente o peso de fluido utilizado durante a perfuração do poço sofre variações de acordo com os eventos ocorridos ao longo da perfuração, como por exemplo perdas para a formação, colapso das paredes do poço e kick. Cada evento possui características que definem a estratégia de mitigação do problema, podendo então o peso de fluido ser elevado o reduzido ao longo do processo de construção do poço.

No presente trabalho foi considerado um peso de fluido único para a perfuração de cada fase, assim como para o peso do fluido de completação utilizado, que se encontra no interior do revestimento de 10.75 pol. A tabela 3.5 apresenta os pesos de fluido utilizados:

Tabela 3.5: Pesos de fluido utilizados para a construção do poço padrão.

\begin{tabular}{|l|c|}
\hline & Peso de fluido [lb/gal] \\
\hline Fase $\mathbf{1}$ & 8.6 \\
\hline Fase $\mathbf{2}$ & 8.6 \\
\hline Fase $\mathbf{3}$ & 11.5 \\
\hline Completação & 9.9 \\
\hline
\end{tabular}

As propriedades térmicas dos fluidos utilizados são as mesmas para todos os anulares do poço. A tabela 3.6 apresenta os valores dos coeficientes de compressibilidade isotérmica e expansão térmica isobárica.

Tabela 3.6: Propriedades térmicas dos fluidos de perfuração utilizados.

\begin{tabular}{|l|c|}
\hline & Fluidos de perfuração \\
\hline$C_{P}$ & $6.67 \times 10^{-10} \mathrm{~Pa}^{-1}$ \\
\hline$C_{T}$ & $8 \times 10^{-4}{ }^{\circ} \mathrm{C}^{-1}$ \\
\hline
\end{tabular}




\section{4}

\section{Malha de elementos finitos}

A malha de elementos finitos utilizada na simulação numérica é composta por elementos quadrilaterais bilineares com graus de liberdade de deslocamento e temperatura. A nomenclatura interna no software ABAQUS é CAX4T (40).

A geometria da malha para a rocha, na direção radial, foi construída de modo que a região próxima à parede do poço possua maior grau de refinamento do que a borda externa do modelo, visto que é nessa região que estão concentrados os maiores níveis de tensão diferencial e deslocamento. Os deslocamentos da região próxima ao poço tem influência direta na variação volumétrica do espaço anular e consequentemente na variação de pressão, que é objetivo de estudo do trabalho. Para o modelo como um todo, incluindo a rocha e os revestimentos, os elementos possuem tamanho constante e iguais a 1 metro na direção vertical. Os revestimentos possuem 2 elementos de espessura igual na direção radial. A figura 3.10 ilustra a variação de refinamento do modelo.

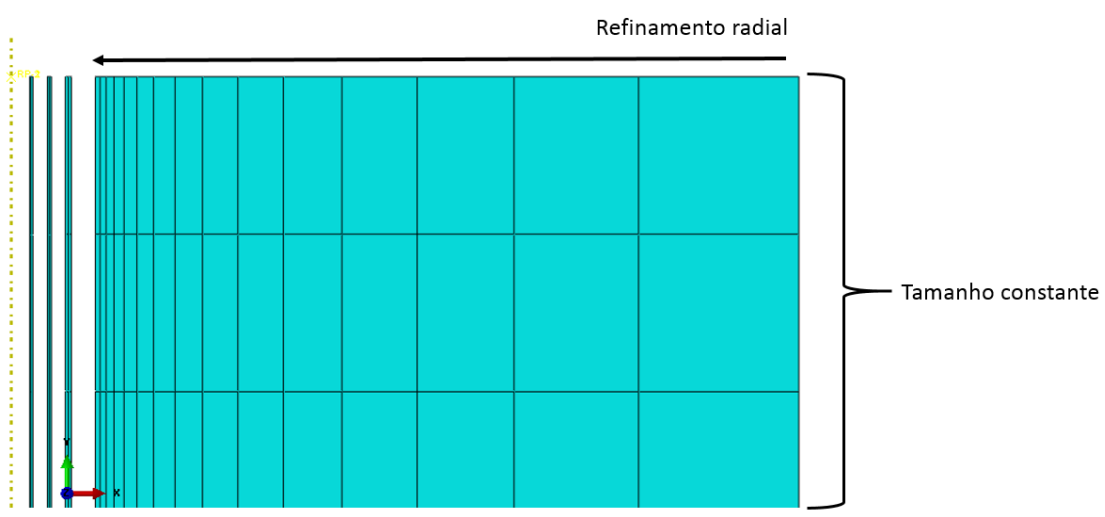

Figura 3.10: Malha de elementos finitos com refinamento na direção radial.

Foram criados casos de simulação com malhas de espessuras de $3 \mathrm{~mm}$, $5 \mathrm{~mm}, 10 \mathrm{~mm}, 20 \mathrm{~mm}$ e $50 \mathrm{~mm}$ na parede do poço e todos terminando com a espessura de $1 \mathrm{~m}$ na borda do modelo. Um poço padrão foi perfurado nessas condições com um peso de fluido de 9.5 ppg na terceira fase (fase do sal). Este peso de fluido foi escolhido de forma a representar um peso de fluido inferior ao em geral utilizado para a perfuração dessa fase e proporcionar um caso severo em termos de deslocamentos da parede do poço e deformações de fluência. Em sequência foi simulado o período de 6 meses após a perfuração e a fluência do sal nesse espaço de tempo.

A figura 3.11 apresenta as curvas de fluência do ponto situado na parede do poço e na base do sal. O nível máximo de deformação de fluência após o fim do período de simulação é apresentado pela tabela 3.7 . 


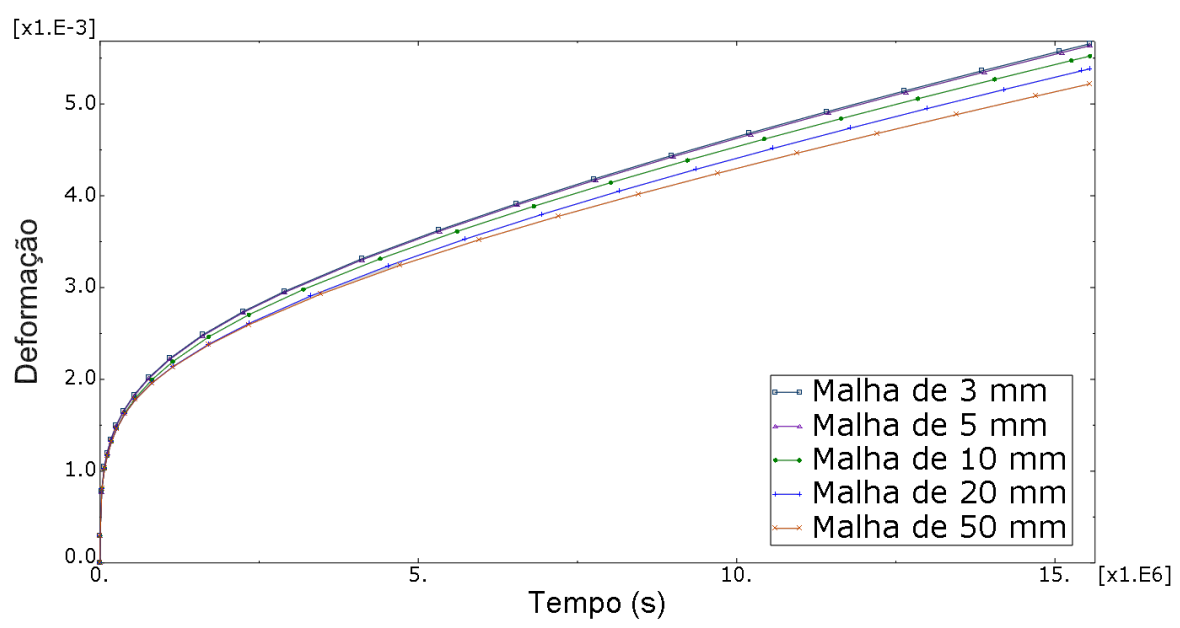

Figura 3.11: Curvas de fluência para um ponto da parede do poço e base do sal, durante o período de 6 meses após a perfuração da fase.

Tabela 3.7: Deformação de fluência após 6 meses.

\begin{tabular}{|l|l|}
\hline & $\epsilon_{\max }$ \\
\hline Malha de $\mathbf{5 0} \mathbf{~ m m}$ & $1.24 \%$ \\
\hline Malha de $\mathbf{2 0} \mathbf{~ m m}$ & $1.29 \%$ \\
\hline Malha de $\mathbf{1 0} \mathbf{~ m m}$ & $1.32 \%$ \\
\hline Malha de $\mathbf{5 m}$ & $1.33 \%$ \\
\hline Malha de $\mathbf{3} \mathbf{~ m m}$ & $1.33 \%$ \\
\hline
\end{tabular}

O nível de deformação máxima de fluência apresenta uma diferença de $7.28 \%$ entre os casos de maior e menor refinamento de malha, correspondentes ao tamanho de $3 \mathrm{~mm}$ e $50 \mathrm{~mm}$ respectivamente.

Não há resposta analítica para o modelo de fluência de duplo mecanismo utilizado neste trabalho. A validação para o efeito do refinamento de malha na fluência do material da parede do poço foi realizada com relação a sua interferência no resultado.

A partir do tamanho de $3 \mathrm{~mm}$ de espessura na parede do poço, a resposta de fluência para este caso severo não apresenta interferência com relação ao refinamento da malha. Logo, este é o nível de refinamento utilizado nas simulações, com o elemento da parede do poço com $3 \mathrm{~mm}$ de espessura radial e de $1 \mathrm{~m}$ na borda externa. Para essa configuração de refinamento adotada, o modelo completo é composto por 98846 elementos, que representam um total de 105898 nós. 


\section{5}

\section{Condições de contorno}

A aplicação das condições de contorno adequadas é de extrema importância em uma modelagem numérica. A sua correta escolha assegura que o modelo numérico se comportará de acordo com as condições reais as quais o problema físico original está sujeito.

\section{Revestimento}

Em um poço de petróleo a coluna de revestimentos é ancorada na cabeça do poço, que suporta o seu peso. Este é seu único ponto de apoio. No modelo numérico esta condição foi representada pela engaste da face superior durante todas as etapas de simulação.

Após a cimentação da fase, o cimento que se encontra no espaço anular formado entre a superfície externa do revestimento e a parede do poço promove resistência ao movimento do revestimento. Neste trabalho a interação mecânica entre o conjunto revestimento, cimento e rocha não foi considerada. A superfície externa do revestimento, em seu trecho cimentado, foi engastada. Esta condição de contorno é uma simplificação do problema real, pois o cimento se deforma em contato com o revestimento. No entanto, esta deformação não contribui para a variação volumétrica do trecho não cimentado acima, cujo comportamento de crescimento de pressão é o interesse deste trabalho.

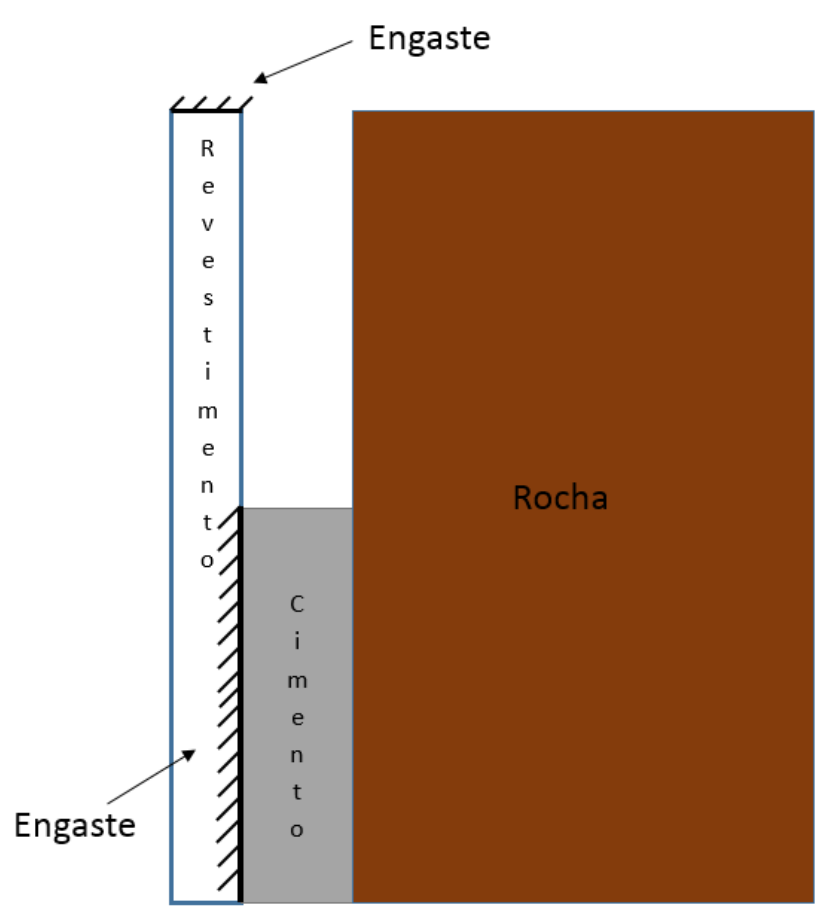

Figura 3.12: Condições de contorno da coluna de revestimento.

\section{Rocha}


O maciço rochoso utilizado na modelagem numérica possui um comprimento de 5 metros na direção radial como mostrado anteriormente, por questões de limitação computacional. Na prática essas formações podem se estender por quilômetros de distância. Na configuração real a fronteira do modelo não é afetada pela presença do poço ou eventos que venham a ocorrer no mesmo. A aresta externa da rocha foi pinada, ou seja, sem deslocamentos em nenhum dos três eixos.

O modelo numérico é um corte do poço real, existindo formações rochosas abaixo. A face inferior foi restringida na direção vertical, podendo se deformar apenas na direção radial.

A figura 3.13 ilustra as condições de contorno na rocha.

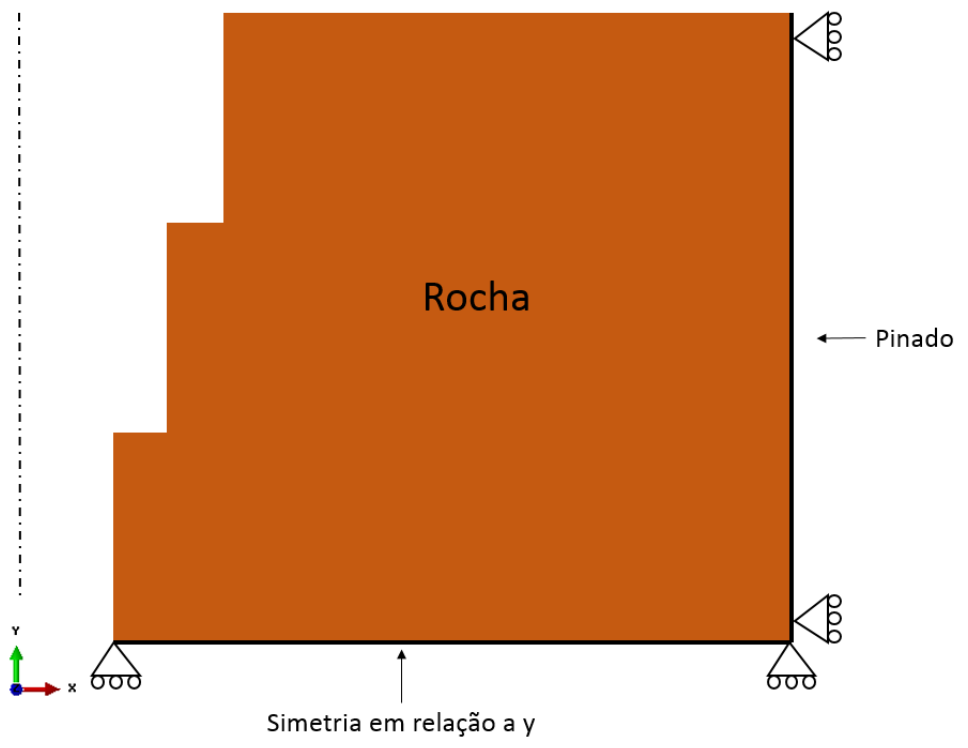

Figura 3.13: Condições de contorno da rocha.

\section{6}

\section{Condições iniciais}

\subsection{1}

\section{Pressão de fluido}

Durante a construção do poço a rocha removida é substituída pelo fluido de perfuração, que dentre muitas funções, promove a sustentação das paredes do poço e serve de meio de transporte para os cascalhos recém cortados. A coluna hidrostática formada é fonte de carregamento para a rocha e para o revestimento que se encontra imerso em fluido de perfuração. A pressão hidrostática exercida pelo peso da coluna de fluido é dada pela equação 3-2.

$$
P_{H}=\rho . g \cdot H
$$


Onde:

- $P_{H}=$ pressão hidrostática

- $\rho=$ massa específica do fluido

- $\mathrm{g}=$ constante gravitacional

$-\mathrm{H}=$ altura da coluna de fluido

$\mathrm{Na}$ indústria do petróleo a forma mais usual do cálculo da pressão da coluna hidrostática se dá em função do gradiente de pressão, que é a razão entre a pressão e a sua profundidade de atuação (39). Porém é comum que o gradiente de pressão seja expresso na unidade de massa específica em lb/gal, para que a comparação com a massa específica do fluido de perfuração utilizado seja mais imediata. Este gradiente é usualmente chamado de "peso de fluido equivalente"ou apenas "peso de fluido".

$$
\rho=\frac{P_{H}}{H \times g}
$$

Com isso pode-se escrever a expressão da pressão da coluna hidrostática do fluido de perfuração, já considerando uma constante de compatibilização de unidades, da seguinte forma:

$$
P_{H}=1174,74 . \rho . H
$$

Onde:

$-P_{H}=$ pressão hidrostática $[\mathrm{Pa}]$

- $\rho=$ peso de fluido [lb/gal]

- $\mathrm{H}=$ altura da coluna de fluido $[\mathrm{m}]$

\subsection{2}

\section{Estado de tensão do revestimento}

A pressão da coluna hidrostática gerada pelo fluido de perfuração age sobre a superfície externa do revestimento que se encontra em contato com o fluido, gerando esforços de ordem compressiva. Adicionalmente, o revestimento que é suspenso pela cabeça do poço, está sujeito ao efeito da gravidade que gera esforços trativos. A figura 3.14 ilustra a configuração na qual o revestimento de espessura uniforme e imerso em um fluido de densidade constante está inserido. 


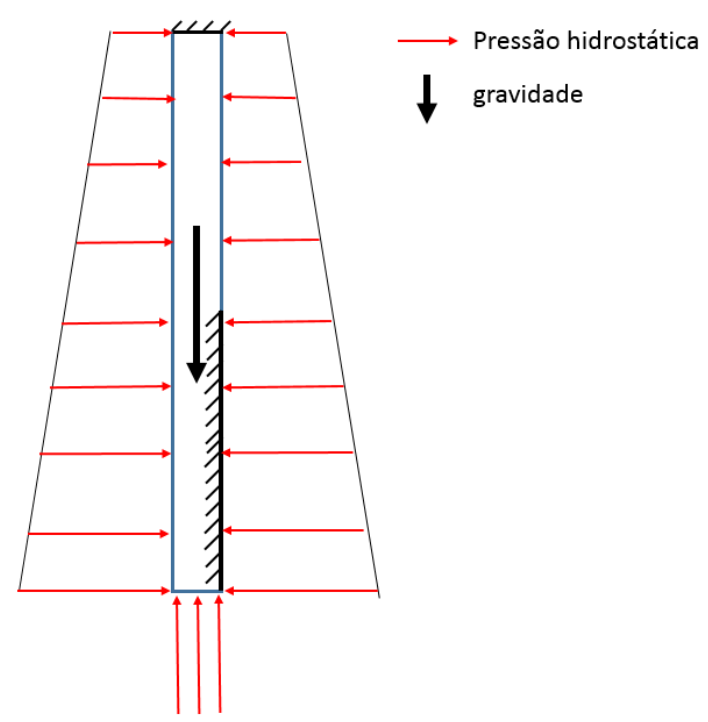

Figura 3.14: Carregamentos sobre a coluna de revestimento.

A tensão axial do revestimento para um determinada profundidade é dada pela equação $3-5$, onde $\mathrm{W}[\mathrm{kg} / \mathrm{m}]$ é o peso linear do tubo.

$$
\sigma(h)=-P_{H_{\text {Sapata }}}+\frac{W \cdot h}{A}
$$

Onde:

- $P_{H_{\text {Sapata }}}=$ pressão hidrostática na sapata

- $\mathrm{W}=$ peso linear do revestimento

- A = área da seção transversal do revestimento

$-\mathrm{h}=$ altura do plano de corte
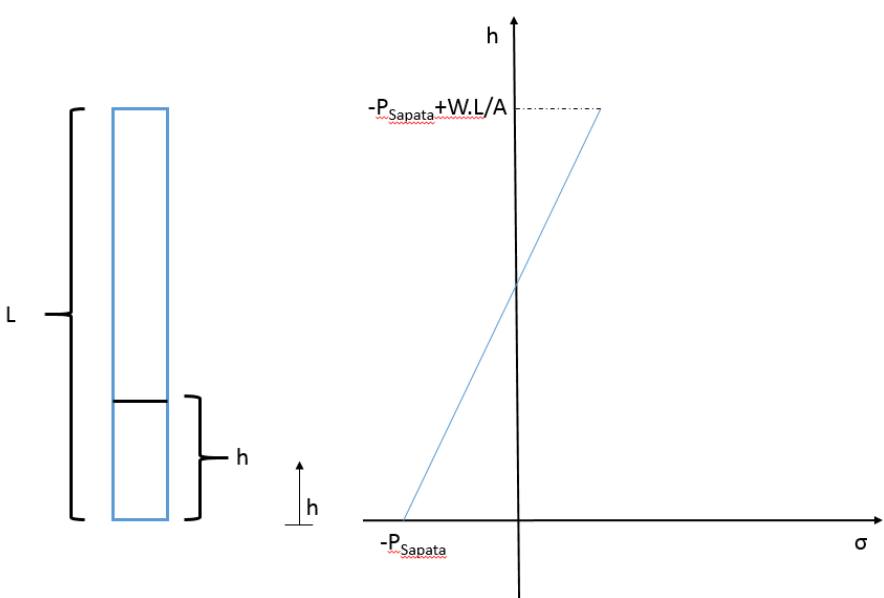

Figura 3.15: Tensão axial da coluna de revestimento.

A partir das equações 3-4 e 3-5 pode-se então definir o estado de tensões axiais ao qual a coluna de revestimento está submetida. 


\subsection{3}

\section{Estado de tensão da rocha}

A rocha que se encontra em subsuperfície está sujeita a um estado de tensão compressivo formado por três tensões principais, uma vertical e duas horizontais, chamado de tensões in-situ.

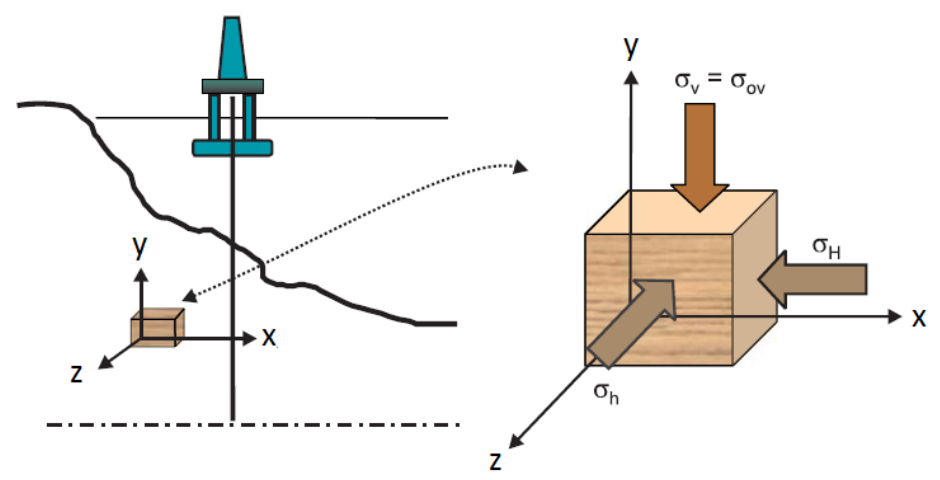

Figura 3.16: Estado de tensões in-situ na rocha (39).

A tensão vertical em um ponto da rocha, também chamada de sobrecarga, é devida ao peso das camadas superiores e pode ser calculada através do somatório do peso da lâmina d'água e das formações superiores, conforme a equação 3-6.

$$
\sigma_{v}=\int_{0}^{y} \rho \cdot g \cdot d y
$$

Para o poço padrão, cuja geometria e composição de materiais foram especificadas anteriormente, pode-se calcular o perfil da tensão de sobrecarga substituindo os valores de densidades e respectivas profundidades na equação 3-6. A tensão vertical é de $-45.68 \mathrm{MPa}$ no topo do sal e de -67.43 MPa na base do sal, o que corresponde a um gradiente de sobrecarga de $11.29 \mathrm{ppg}$ e $12.89 \mathrm{ppg}$ respectivamente. Neste caso a base do sal foi considerada na profundidade de $4456 \mathrm{~m}$, correspondente ao topo do cimento (base do anular A) e não ao fim da fase $3(4961 \mathrm{~m})$. O gráfico da figura 3.17 ilustra o perfil da tensão de sobrecarga ao longo da profundidade de um poço padrão. 


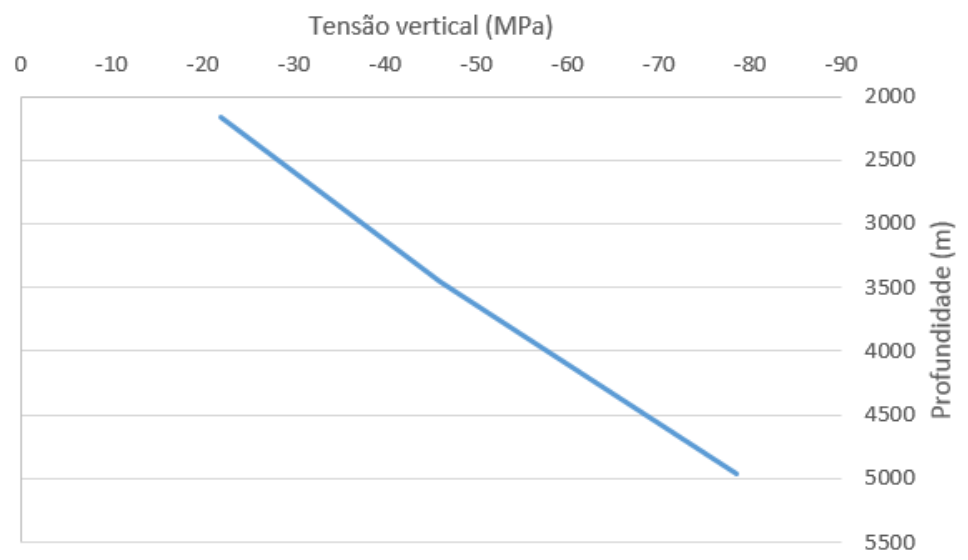

Figura 3.17: Tensão de sobrecarga para o poço padrão.

Em virtude do carregamento de sobrecarga, a rocha tende a se deformar lateralmente. No entanto, este deslocamento é restringido pela presença de formações vizinhas e tensões in-situ horizontais são geradas, podendo essas serem iguais ou não (41).

Geralmente a tensões horizontais são expressas como uma relação entre a tensão vertical e as horizontais, conforme a equação 3-7. As tensões horizontais foram consideradas iguais, sendo então o valor de $\mathrm{K}$ igual para ambas as direções horizontais ( $\mathrm{x}$ e $\mathrm{z}$ ).

$$
K=\frac{\sigma_{h}}{\sigma_{v}}
$$

A tabela 3.8 apresenta os valores de K utilizados na modelagem numérica deste trabalho.

Tabela 3.8: Valores de K utilizados no modelo numérico.

\begin{tabular}{|c|c|c|}
\hline & Sal & Pós-sal \\
\hline $\mathbf{K}$ & 1 & 0.87 \\
\hline
\end{tabular}




\section{4}

\section{Metodologia de Simulação}

A metodologia utilizada no modelo de elementos finitos compreende desde a construção até a produção do poço. Ao longo da produção ocorre o aquecimento do poço e consequentemente o fenômeno de APB, acoplado ao processo de fluência da rocha salina e deformação das estruturas que compõem o sistema.

\section{1}

\section{Construção do poço}

A etapa de construção do poço consiste na perfuração de uma fase e posterior instalação da coluna de revestimento. O processo se repete até a construção da última fase do poço, que no caso do poço padrão é terceira fase.

\subsection{1}

\section{Perfuração}

Inicialmente a rocha está sujeita a seu estado de tensão original, conforme mostrado na seção 3.6.3. A perfuração é então simulada através da aplicação da pressão hidrostática do fluido de perfuração na superfície da parede do poço aberto.
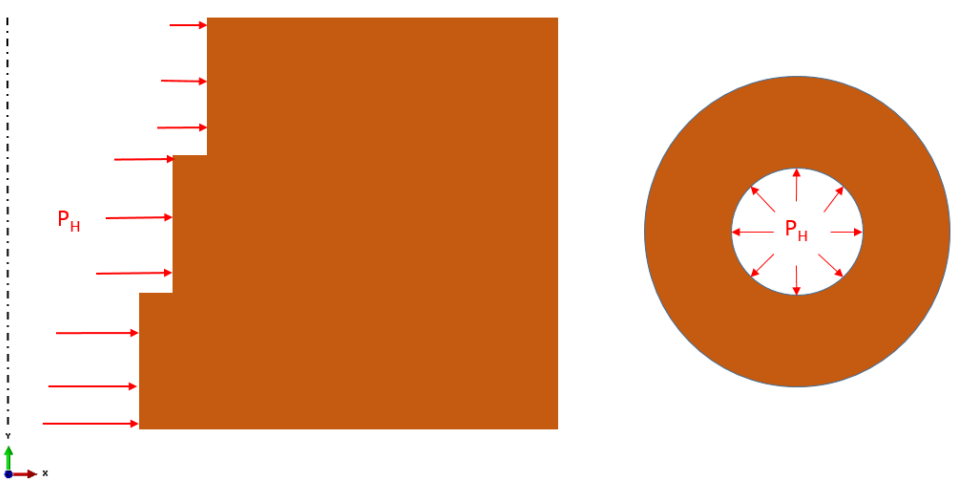

Figura 4.1: Pressão de fluido aplicada na parede do poço durante a etapa de perfuração. Na esquerda, uma vista axissimétrica do modelo e na direita, um corte da seção transversal.

A validação do estado de tensão pós perfuração foi realizado comparando a solução numérica encontrada com a resposta analítica obtida através das 
equações de Kirsch para um furo em uma placa plana infinita em estado plano de deformação (42).

A profundidade de 2170 metros, referente a um ponto da fase de 36 ", foi escolhida como ponto de controle para a validação do estado de tensão pós perfuração. Para a perfuração da fase foi utilizado um fluido de perfuração de peso 8.6 ppg. A tabela 4.1 apresenta os valores iniciais da simulação realizada.

Tabela 4.1: Estado de tensão inicial do ponto de controle.

\begin{tabular}{|l|r|}
\hline$P_{H}$ & $21.92 \mathrm{MPa}$ \\
\hline$\sigma_{v}$ & $-22.14 \mathrm{MPa}$ \\
\hline$\sigma_{h}$ & $-14,83 \mathrm{MPa}$ \\
\hline
\end{tabular}

O gráfico da figura 4.2 apresenta o estado de tensão após a perfuração do poço na profundidade de 2170 metros, onde x é a distância radial a partir da parede do poço ( $x=0$ na parede).

O modelo numérico apresenta resultado com ótima aderência à solução analítica. A tensão vertical se mantém constante ao longo da direção radial e as tensões radiais e tangenciais se aproximaram do estado de tensão original à medida que se afastam da parede do poço (região não afetada pela perfuração).

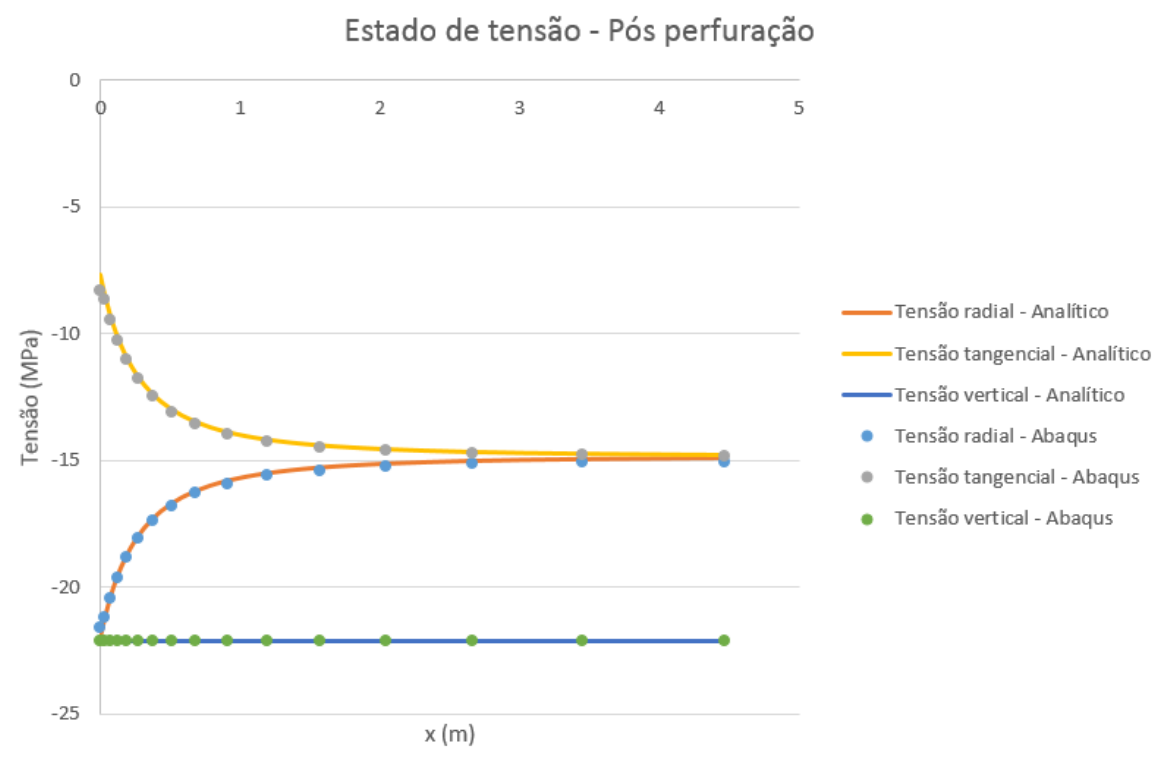

Figura 4.2: Estado de tensão pós perfuração para a profundidade do ponto de controle a 2170 metros.

\subsection{2}




\section{Descida de revestimento}

Após a perfuração da fase é instalado o revestimento correspondente. A coluna de revestimento é ancorada na cabeça do poço e se encontra imersa em fluido de perfuração presente no poço.

A tensão vertical teórica é descrita pela equação 3-5 e as superfícies que formam o contorno (externa, interna e inferior) estão submetidas a pressão hidrostática do fluido de perfuração.

O revestimento de 30" foi utilizado para a validação do estado de tensões após sua instalação, que ocorre em sequência da perfuração da fase de 36". Este elemento tubular possui peso linear de $554 \mathrm{lb} / \mathrm{ft}$ e se encontra imerso em fluido de perfuração de 8.6 ppg que foi utilizado para a perfuração da fase de $36 "$ e $26 "$.

O gráfico da figura 4.3 apresenta o resultado obtido após a instalação do revestimento de 30". A tensão axial calculada pelo ABAQUS segue fielmente a resposta proposta pela formulação analítica.

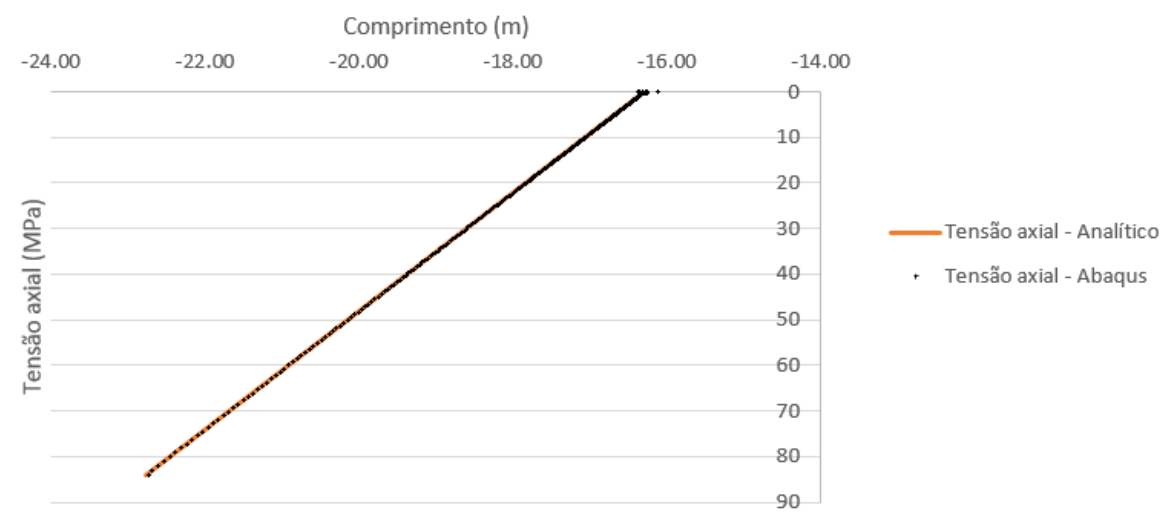

Figura 4.3: Tensão axial do revestimento de 30".

\section{2}

\section{Produção e fenômeno de APB}

Após a etapa de construção, o poço se encontra pronto para o início da produção e consequentemente para o desenvolvimento do fenômeno de crescimento de pressão em anular confinado.

No começo deste estágio o poço está a uma temperatura que segue o gradiente geotérmico original. A tabela a seguir lista os valores de temperatura utilizados para o poço padrão: 
Tabela 4.2: Temperaturas iniciais para o poço padrão.

\begin{tabular}{|l|c|c|}
\hline & Temperatura & Profundidade \\
\hline Fundo do mar & $4{ }^{\circ} \mathrm{C}$ & $2169 \mathrm{~m}$ \\
\hline Topo do sal & $47.45{ }^{\circ} \mathrm{C}$ & $3444 \mathrm{~m}$ \\
\hline Base do sal & $60.98^{\circ} \mathrm{C}$ & $4961 \mathrm{n}$ \\
\hline
\end{tabular}

Com o início da produção, o hidrocarboneto quente escoa pela coluna de produção, aquecendo o seu entorno. O novo perfil térmico do poço incluindo rocha, revestimento e fluido dos anulares será calculado com o software Wellcat, que fornece a distribuição de temperatura atualizada para um dado tempo desejado.

O processo de aquecimento tem duração de alguns meses para chegar a sua temperatura de equilíbrio, dependendo das condições iniciais e de produção do poço. Neste trabalho foi considerado o período de tempo de 4096 horas (5.5 meses) como intervalo de tempo total até o fim do aquecimento do poço. O gráfico da figura 4.4 ilustra as distribuições de temperatura inicial, após 4096 horas e no equilíbrio final (tempo infinito). É possível notar que a curva de temperatura após 4096 horas se confunde com a curva de equilíbrio. Um tempo de simulação superior elevaria o custo computacional e não acarretaria aumento de pressão no anular, visto que não haveria um significativo aquecimento.

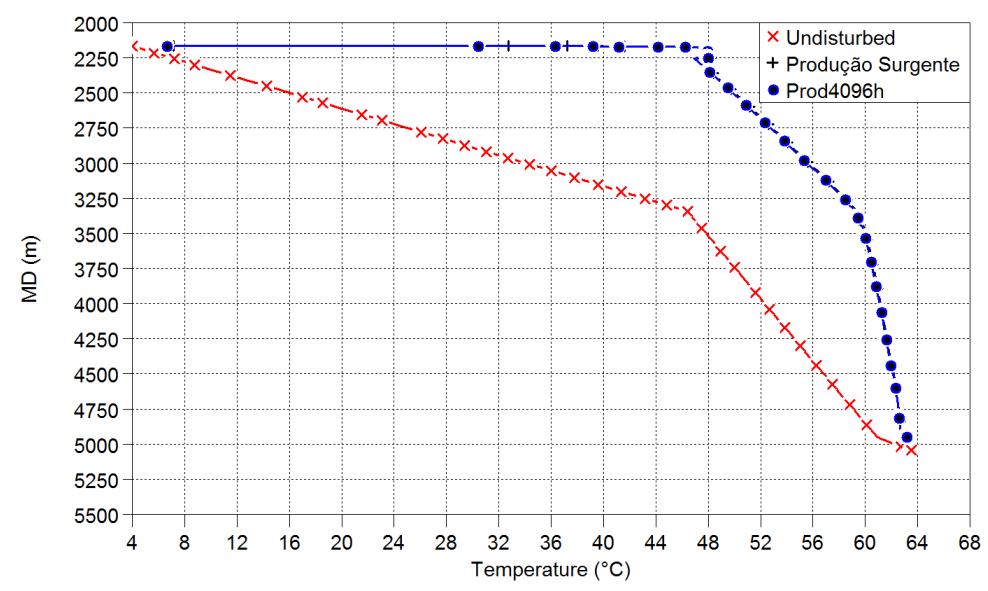

Figura 4.4: Perfil térmico após 4096 horas em comparação com o perfil de equilíbrio.

A pressurização do fluido confinado em um determinado anular, foi simulada através da injeção de massa correspondente ao volume expandido entre dois perfis térmicos distintos. Na realidade, considerando o anular completamente selado, ou seja, sem vazamentos para anulares vizinhos e/ou 
perdas para a formação, a massa do sistema permanece constante. Este foi o artifício numérico adotado, para simular a expansão volumétrica do fluido de perfuração.

A massa injetada no intervalo de tempo entre dois perfis térmicos pode ser obtida pela multiplicação da variação volumétrica, determinada pela equação 4-11, e a densidade do fluido de perfuração.

$$
\begin{gathered}
\Delta m=\rho \Delta V \\
\Delta m=C_{T} \rho A \int\left[T_{j}(y)-T_{i}(y)\right] d y
\end{gathered}
$$

O tempo total de simulação foi dividido em 13 intervalos, variando de 1 hora até o tempo total de 4096 horas, de modo que cada tempo de simulação seja o dobro do anterior.

$$
t_{i}=2^{i}, \quad \text { onde } \quad 0<i<12
$$

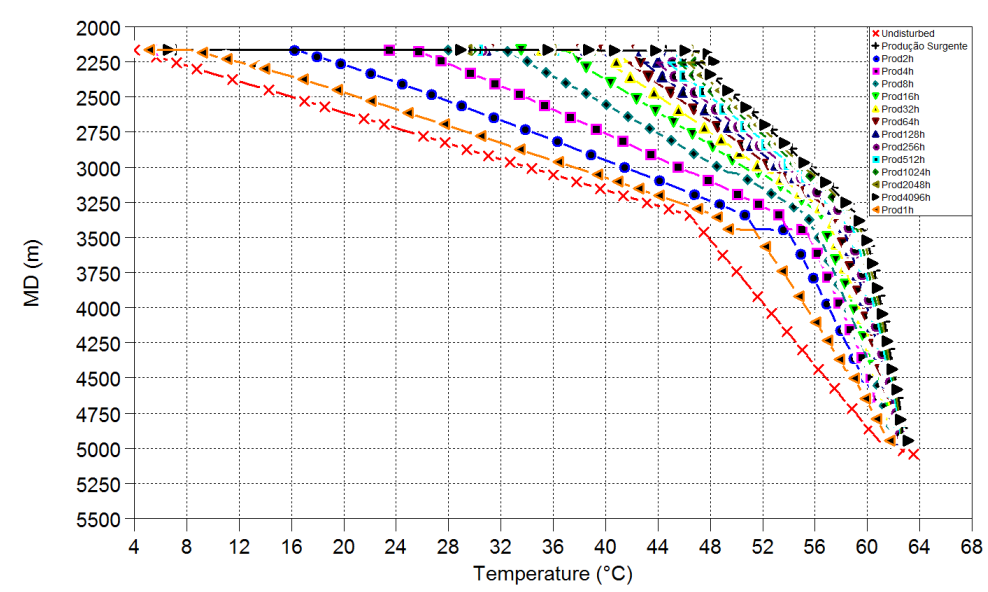

Figura 4.5: Perfis térmicos para os tempos $t_{i}$.

Entre dois intervalos de tempo $t_{i}$ consecutivos é calculada a massa a ser injetada e a mesma é aplicada com uma vazão constante determinada pela equação 4-4.

$$
Q_{i}=\frac{\Delta m_{i}}{t_{i+1}-t_{i}}
$$

O fluxograma da figura 4.6 exemplifica o processo de expansão térmica. 


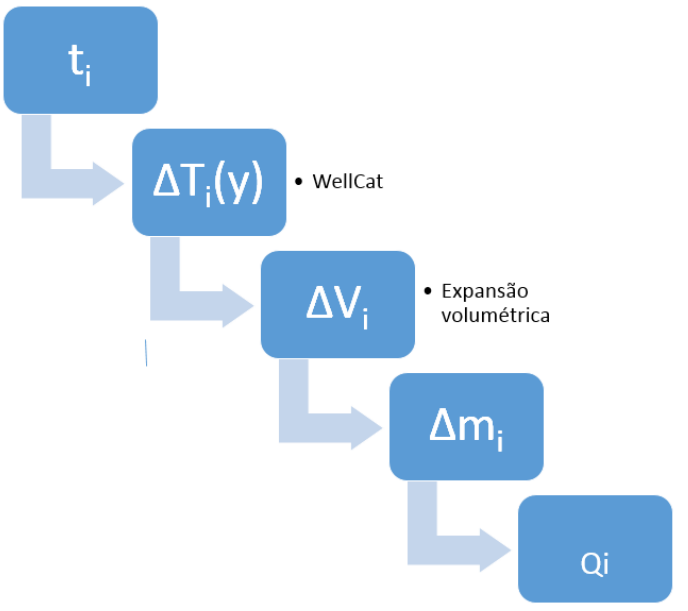

Figura 4.6: Fluxograma da rotina de expansão térmica.

Recapitulando, para cada tempo de simulação $t_{i}$, é obtido através do Wellcat o perfil térmico $T_{i}(y)$. A expansão volumétrica entre dois momentos é calculada e em seguida a correspondente variação mássica é injetada no anular através de uma vazão constante $Q_{i}$. Este processo ocorre simultaneamente e de forma acoplada ao processo de fluência da formação salina e deformação elástica do sistema (rochas e revestimentos).

\subsection{1}

\section{Expansão térmica}

O fluido do anular irá se expandir devido ao aumento de temperatura causado pela produção do poço. O volume de fluido contido no anular perfeitamente selado (sem vazamentos ou perdas para a formação) é função da pressão e da temperatura e pode ser escrito através da seguinte relação:

$$
\partial V=\left(\frac{\partial V}{\partial T}\right)_{P} \partial T+\left(\frac{\partial V}{\partial P}\right)_{T} \partial P
$$

Para o caso de uma expansão volumétrica irrestrita, ou seja, sem a restrição imposta pela fronteira, o último termo da equação 4-5 se anula. Logo, temos:

$$
\partial V=\left(\frac{\partial V}{\partial T}\right)_{P} \partial T
$$

O coeficiente de expansão térmica é determinado pela seguinte expressão:

$$
C_{T}=\frac{1}{V}\left(\frac{\partial V}{\partial T}\right)_{P}
$$

Substituindo 4-7 em 4-6 chega-se à relação:

$$
\partial V=C_{T} \cdot V \cdot \partial T
$$


A equação 4-8 relaciona a expansão volumétrica com o aquecimento do fluido (43). Integrando-se esta equação ao longo de todo o anular o aumento total de volume devido ao incremento de temperatura pode ser determinado.

Seja $T_{i}(y)$ e $T_{j}(y)$ dois perfis térmicos em instantes distintos durante a produção do poço. A variação de temperatura entre esses dois momentos, para uma determinada profundidade do poço é dada por:

$$
\Delta T(y)=T_{j}(y)-T_{i}(y)
$$

A variação volumétrica total do fluido anular pode ser escrita como:

$$
\Delta V=\int C_{T}\left[T_{i}(y)-T_{j}(y)\right] d V
$$

Por simplificação a área transversal foi considerada constante em toda a extensão de um determinado anular, para o instante de início do aquecimento. Na prática há uma pequena diferença que foi desprezada, visto que o nível de deformação da parede do poço varia ao longo da profundidade que está sujeita a diferentes estados de tensão. No entanto, o nível de deformações elásticas iniciais na parede do poço, que são da ordem de milímetros, pouco contribuem para a variação volumétrica inicial.

A equação 4-10 pode ser reescrita da seguinte forma:

$$
\Delta V=C_{T} A \int\left[T_{j}(y)-T_{i}(y)\right] d y
$$

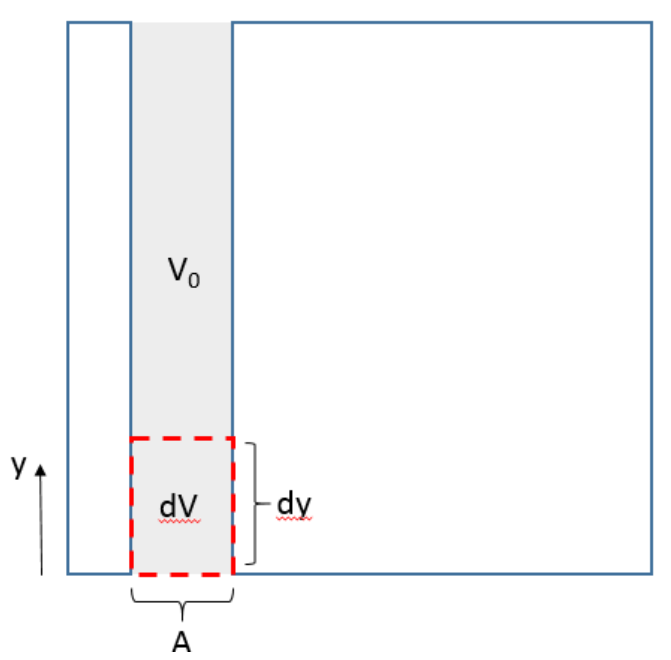

Figura 4.7: Expansão volumétrica de um volume de controle.

A partir da equação 4-11 pode-se então calcular a variação volumétrica total do fluido presente em um anular que é aquecido entre dois perfis térmicos distintos. 


\subsubsection{1}

\section{Pressurização do anular}

O fluido contido nos anulares do poço irá se pressurizar, uma vez que a expansão volumétrica é restringida pela resistência mecânica imposta pela fronteira (rocha e revestimento). A equação 2-4 relaciona a variação de pressão com a variação de temperatura e de volume do anular.

O cálculo da expansão volumétrica devido ao aquecimento do fluido de perfuração é realizado no software Microsoft Excel a partir dos parâmetros geométricos do anular, coeficiente de expansão térmica do fluido e perfis térmicos determinados pelo Wellcat (vide equação 4-11 ).

As vazões mássicas ao longo do tempo de produção são então determinadas e inseridas ao modelo afim de representar a variação volumétrica devido exclusivamente à parte térmica do problema (primeiro termo da equação 2-4).

O modelo de elementos finitos calcula as deformações do sistema (rocha e revestimento) e determina a variação volumétrica do anular (segundo termo da equação 2-4). Com isso a compatibilização das pressões anulares pode ser determinada. O fluxograma da figura 4.8 exemplifica a rotina de cálculo.
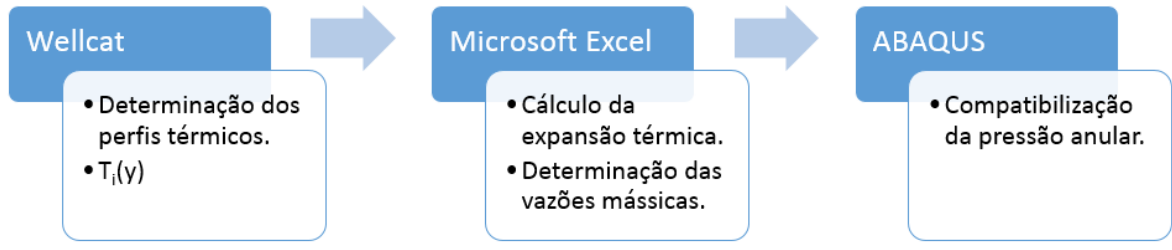

Figura 4.8: Fluxograma de cálculo da compatibilização de pressão anular. 


\section{Resultados}

A modelagem numérica desenvolvida neste trabalho foi aplicada a cenários distintos para a investigação da influência da presença da rocha salina e configurações do poço, no crescimento de pressão em anulares confinados.

\section{1}

\section{Caso base}

As simulações a seguir utilizam a configuração e geometria do poço padrão apresentadas na seção 3. A figura 5.1 resume as informações geométricas do caso base.

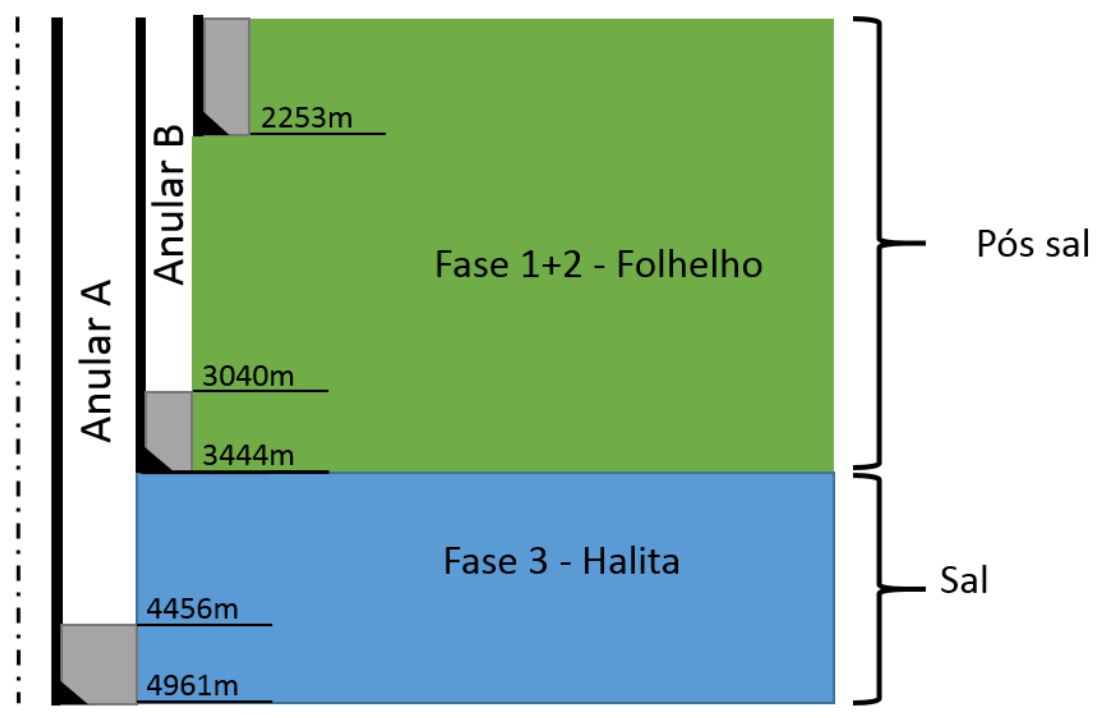

Figura 5.1: Resumo da geometria do caso base.

As tabelas 5.1 e 5.2 resumem respectivamente os parâmetros dos fluidos de perfuração utilizados e as condições de tensão e temperatura iniciais do sal, conforme detalhado na seção 3.

Tabela 5.1: Propriedades dos fluidos utilizados no caso base

\begin{tabular}{|l|c|c|}
\hline & Anular A & Anular B \\
\hline$\rho$ & $11.5 \mathrm{ppg}$ & $8.6 \mathrm{ppg}$ \\
\hline$C_{T}$ & $8 \times 10^{-4}{ }^{\circ} \mathrm{C}^{-1}$ \\
\hline$C_{P}$ & \multicolumn{2}{|c|}{$6.67 \times 10^{-10} \mathrm{~Pa}$} \\
\hline
\end{tabular}


Tabela 5.2: Resumo de condições de tensão e temperatura do sal.

\begin{tabular}{|l|c|c|}
\hline & Topo do sal & Base do sal \\
\hline Temperatura & $47.45{ }^{\circ} \mathrm{C}$ & $60.98{ }^{\circ} \mathrm{C}$ \\
\hline Tensão in-situ & $-45.68 \mathrm{MPa}$ & $-67.43 \mathrm{MPa}$ \\
\hline Gradiente de sobrecarga & $11.29 \mathrm{ppg}$ & $12.89 \mathrm{ppg}$ \\
\hline
\end{tabular}

Os parâmetros da base do sal da tabela 5.2 se referem a profundidade de 4456 metros, que representa a base do anular A (topo do cimento) e não ao fim da fase 3 que está na profundidade de 4961 metros.

\subsection{1}

\section{Modelo elástico}

Inicialmente foi simulado o caso base, já definido acima, considerando a rocha salina apenas com comportamento elástico, ou seja, o processo de fluência (comportamento viscoelástico) não foi incluído na modelagem. Dessa forma pode-se comparar posteriormente o crescimento de pressão no mesmo cenário, adicionando o comportamento viscoelástico da rocha salina e sua influência então pode ser avaliada.

A produção do poço foi simulada no software Wellcat, considerando uma vazão de óleo de $10000 \mathrm{bpd}$ a $63.54{ }^{\circ} \mathrm{C}$ (temperatura do óleo no reservatório). Para esta vazão de produção, após a condição de equilíbrio atingida em 4096 horas, o fluido contido no anular A sofre uma variação térmica de $0.4{ }^{\circ} \mathrm{C}$ em sua base e de $10.2{ }^{\circ} \mathrm{C}$ no topo do sal. A variação máxima de temperatura ocorrida no anular A é de $38.78^{\circ} \mathrm{C}$, localizada na profundidade de 2188.56 metros. No anular B, a variação máxima de temperatura é de $26.37^{\circ} \mathrm{C}$ na profundidade de 2188.56 metros e a base do anular a 3040 metros apresentou variação térmica de $11.78^{\circ} \mathrm{C}$.

Os perfis de temperatura ao longo do tempo para os anulares A e B até o período máximo de 4096 horas (5.7 meses) são apresentados respectivamente nas figuras 5.2 e 5.3. O aquecimento dos fluidos dos anulares converge para o equilíbrio após 4096 horas, tempo no qual a temperatura no tempo infinito foi aproximada. 


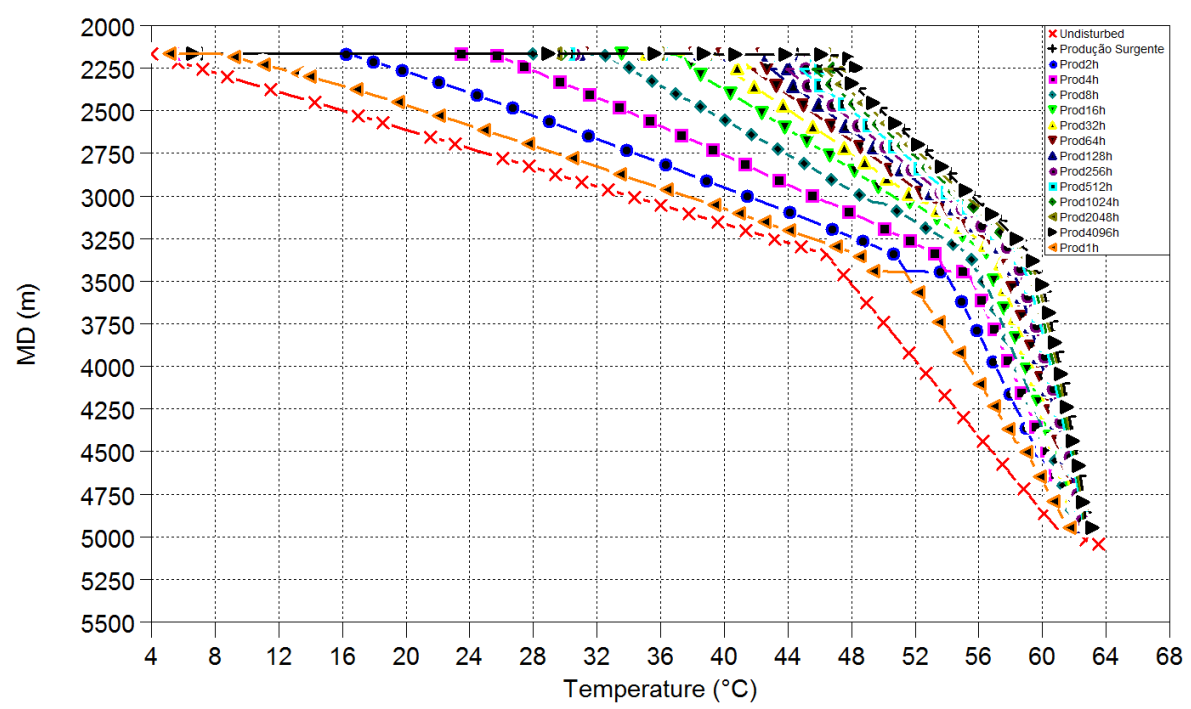

Figura 5.2: Perfis de temperatura simulados pelo software Wellcat para o fluido do anular A.

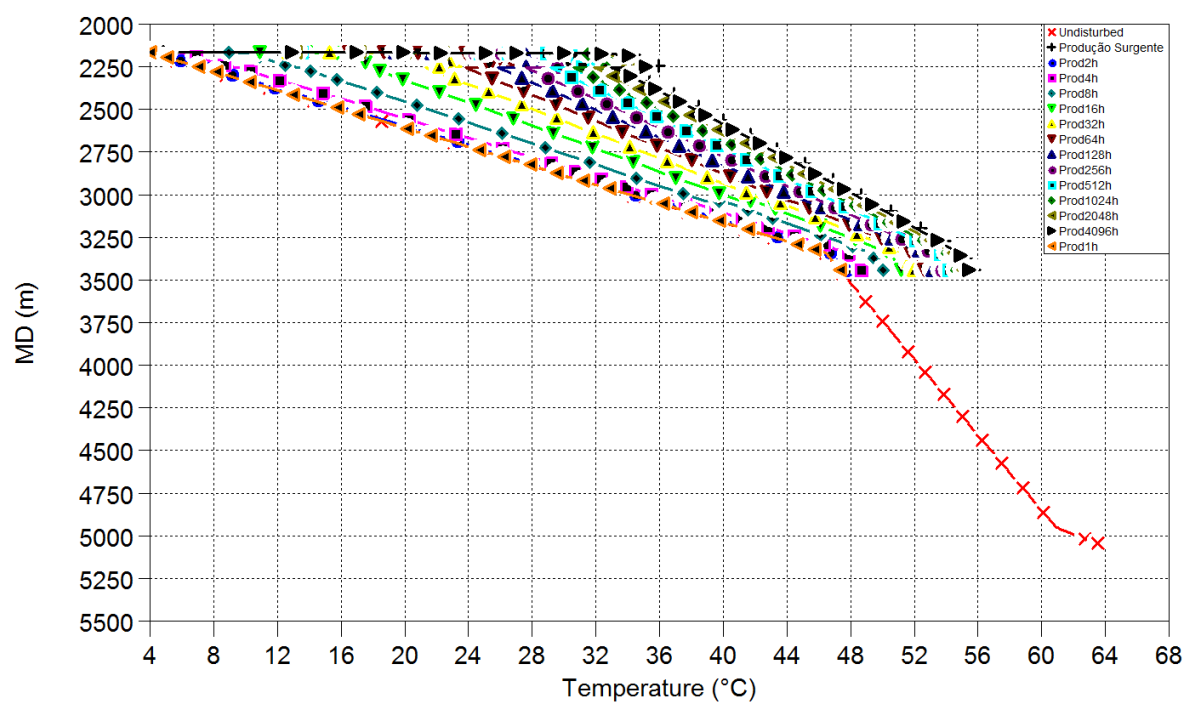

Figura 5.3: Perfis de temperatura simulados pelo software Wellcat para o fluido do anular B.

A partir dos perfis térmicos calculados através do software Wellcat, pode-se determinar a expansão térmica do fluido de perfuração confinado nos anulares do poço. A tabela 5.3 apresenta as variações volumétricas irrestritas, apenas devido ao aquecimento, para ambos anulares, calculadas pela equação 4-11. 
Tabela 5.3: Variação volumétrica irrestrita total, após término do aquecimento

\begin{tabular}{|l|c|c|}
\hline & Anular A & Anular B \\
\hline$V_{0}$ & $187.58 \mathrm{~m}^{3}$ & $124.11 \mathrm{~m}^{3}$ \\
\hline$\Delta V$ & $2.86 \mathrm{~m}^{3}$ & $1.84 \mathrm{~m}^{3}$ \\
\hline$\frac{\Delta V}{V_{0}}$ & $1.52 \%$ & $1.48 \%$ \\
\hline
\end{tabular}

A partir das variações volumétricas irrestritas calculadas através da equação 4-11, pode-se então determinar as vazões mássicas utilizadas ao longo da simulação numérica. Na prática, considerando o anular completamente selado, a massa do sistema permanece constante. Este foi o artifício numérico adotado, para simular a expansão volumétrica do fluido de perfuração.

A tabela 5.4 contém os valores das variações volumétricas e suas respectivas vazões de injeção de fluido.

Tabela 5.4: Expansão volumétrica para o caso base.

\begin{tabular}{|l|c|c|c|c|}
\hline & $\Delta m_{A}[\mathrm{~kg}]$ & $\Delta m_{B}[\mathrm{~kg}]$ & $Q_{A}\left[10^{-6} \mathbf{k g} / \mathbf{s}\right]$ & $Q_{B}\left[10^{-6} \mathbf{k g} / \mathbf{s}\right]$ \\
\hline $\mathbf{1 h}$ & 386.25 & 1.98 & 107292.55 & 550.16 \\
\hline $\mathbf{2 h}$ & 631.16 & 20.85 & 175321.82 & 5792.64 \\
\hline $\mathbf{4 h}$ & 814.34 & 109.33 & 113103.84 & 15184.74 \\
\hline $\mathbf{8 h}$ & 669.72 & 266.13 & 46508.22 & 18481.22 \\
\hline $\mathbf{1 6 h}$ & 416.25 & 333.09 & 14453.61 & 11565.70 \\
\hline $\mathbf{3 2 h}$ & 260.08 & 278.43 & 4515.22 & 4833.85 \\
\hline $\mathbf{6 4 h}$ & 169.35 & 199.68 & 1470.07 & 1733.34 \\
\hline $\mathbf{1 2 8 h}$ & 130.08 & 152.81 & 564.57 & 663.24 \\
\hline $\mathbf{2 5 6 h}$ & 111.34 & 130.14 & 241.62 & 282.43 \\
\hline $\mathbf{5 1 2 h}$ & 100.04 & 116.51 & 108.55 & 126.42 \\
\hline $\mathbf{1 0 2 4 h}$ & 91.17 & 106.20 & 49.47 & 57.62 \\
\hline $\mathbf{2 0 4 8 h}$ & 82.54 & 97.21 & 22.39 & 26.37 \\
\hline $\mathbf{4 0 9 6 h}$ & 73.32 & 87.23 & 9.95 & 11.83 \\
\hline
\end{tabular}

Considerando a restrição à expansão volumétrica do fluido de perfuração imposta pela rigidez da fronteira que determina o espaço anular (rocha e coluna de revestimento), a variação volumétrica total foi de $1.2 \mathrm{~m}^{3}$ para o anular A e de $1.33 \mathrm{~m}^{3}$ para o anular $\mathrm{B}$, que corresponde a uma variação percentual de $0.64 \%$ e $1.07 \%$ respectivamente.

A evolução do acréscimo de pressão nos anulares A e B do poço é apresentada no gráfico da figura 5.4. Os picos de acréscimo de pressão possuem valores de $17.82 \mathrm{MPa}$ e $10.8 \mathrm{MPa}$ nos anulares A e B respectivamente. Os acréscimos máximos de pressão são atingidos ao final do tempo de simulação. 


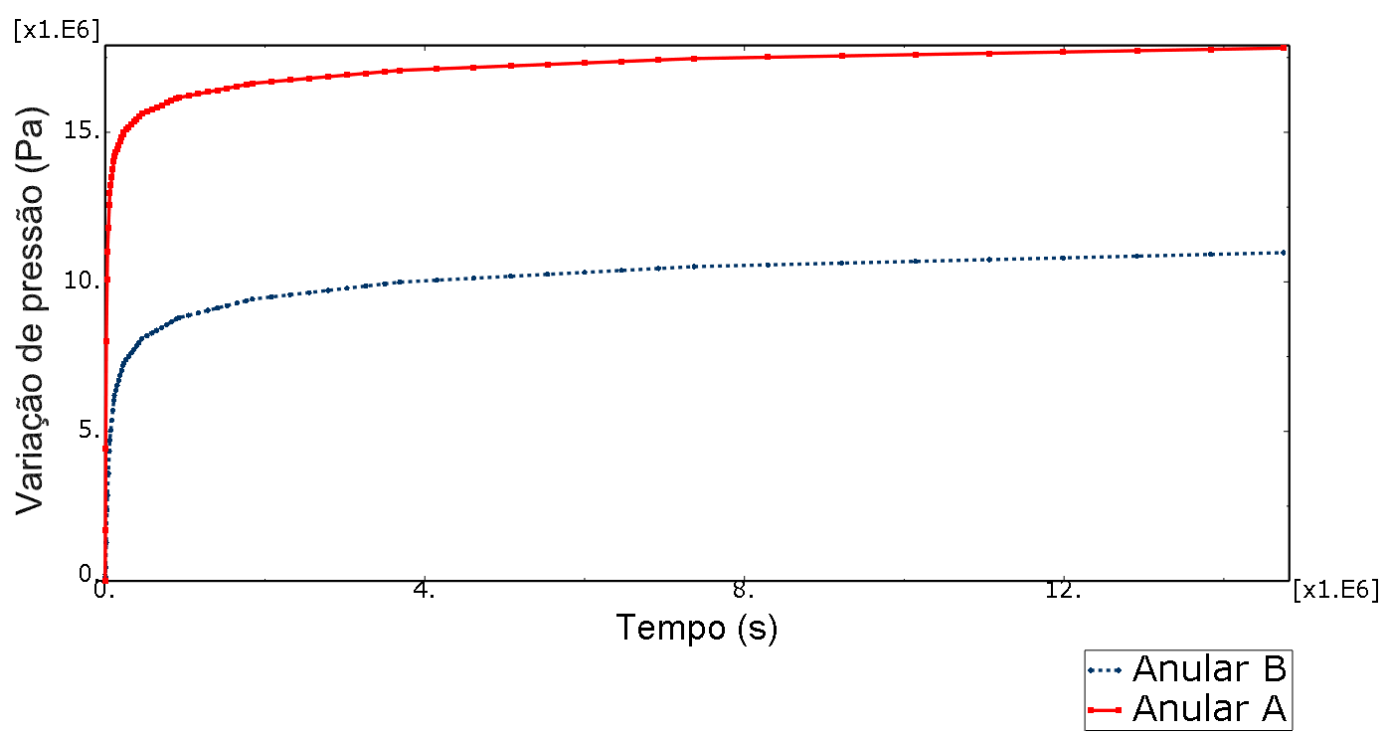

Figura 5.4: Evolução do acréscimo de pressão nos anulares A e B para o caso puramente elástico.

O fluido de perfuração do anular A possui peso equivalente de 11.5 ppg ao início da produção. Este acréscimo de 17.82 MPa gera um peso equivalente de 15.9 ppg na sapata do revestimento de 20 pol (profundidade de $3444 \mathrm{~m}$ ), que é o ponto em geral mais fraco ao longo da fase. Esta condição representa um acréscimo de $38.26 \%$ no peso de fluido equivalente da sapata da fase 2 .

No anular B o acréscimo de $10.8 \mathrm{MPa}$ gera uma variação no peso de fluido na sapata do revestimento anterior, neste caso de 30 pol, de 8.6 ppg para 12.68 ppg. Este acréscimo de pressão representa um aumento de $47.44 \%$ no peso de equivalente na sapata da fase 1.

\section{1 .2 \\ Modelo viscoelástico}

A seguir, foi implementando o comportamento viscoelástico da rocha salina, segundo o modelo de fluência de duplo mecanismo. Todas as condições e parâmetros consideradas anteriormente no caso base puramente elástico foram mantidas, apenas se adicionando este comportamento viscoelástico do material salino. Os perfis térmicos calculados pelo Wellcat e consequentemente as vazões de injeção utilizadas também se mantém, visto que as condições de temperatura e do coeficientes de expansão térmica e compressibilidade do fluido não se alteram.

Após a construção do poço foi simulado o intervalo de tempo de 6 meses até o início da produção do poço e consequentemente o aquecimento do anular e início do fenômeno de APB. Este período contempla o tempo para a 
completação do poço e demais atividades até que a produção possa ser iniciada. Na simulação anterior, do caso puramente elástico, este intervalo de tempo que precede a produção não foi considerado, visto que a condição do poço não sofreria modificação, pois a rocha não tem comportamento dependente do tempo.

Neste período de tempo, a rocha salina apresenta deformação por fluência, que altera o volume e a pressão do anular, visto que a pressão gerada nas paredes do poço pelo fluido de perfuração é diferente da tensão in-situ da rocha salina. O sal está inicialmente em um estado de tensão hidrostático (tensão de von Mises nula). A concentração de tensão criada ao redor do poço gera uma tensão de von Mises que é o vetor direcionador da deformação por fluência no modelo de duplo mecanismo.

O gráfico da figura 5.5 apresenta a tensão de von Mises e o deslocamento radial de pontos localizados na parede do poço, ao longo do trecho salino, para os instantes imediatamente após a construção do poço e ao fim do período de 6 meses que precede a produção. O topo do sal possui tensão in-situ inferior à pressão gerada pelo fluido de perfuração, o que gera deslocamentos positivos (no sentido de abrir o poço). A medida que a profundidade aumenta essa diferença diminui até que, após se igualarem, a diferença de tensão começa a aumentar. Este comportamento é representado no gráfico pela inversão do comportamento do deslocamento e da tensão de Mises ao longo da espessura de sal. Ao final do período de 6 meses a base do sal a $4456 \mathrm{~m}$ apresenta um deslocamento radial de $-1.7 \times 10^{-4} \mathrm{~m}$.

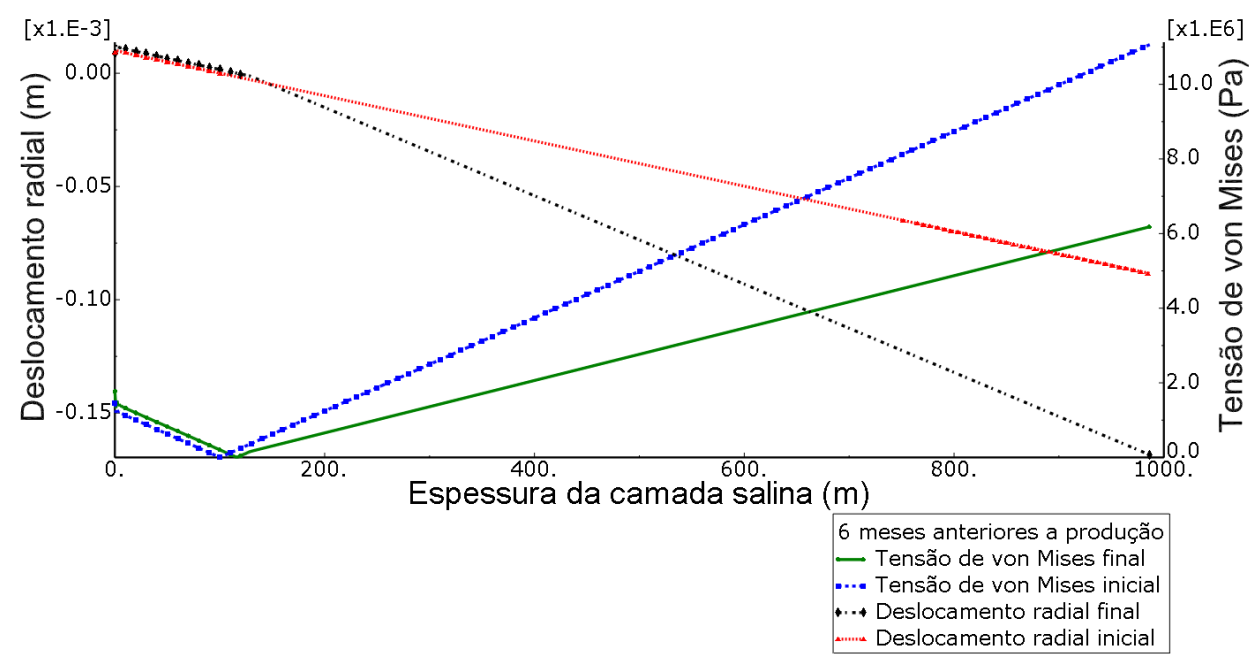

Figura 5.5: Tensão de von Mises e deslocamento radial dos pontos localizados na parede do poço, ao longo do trecho salino. 


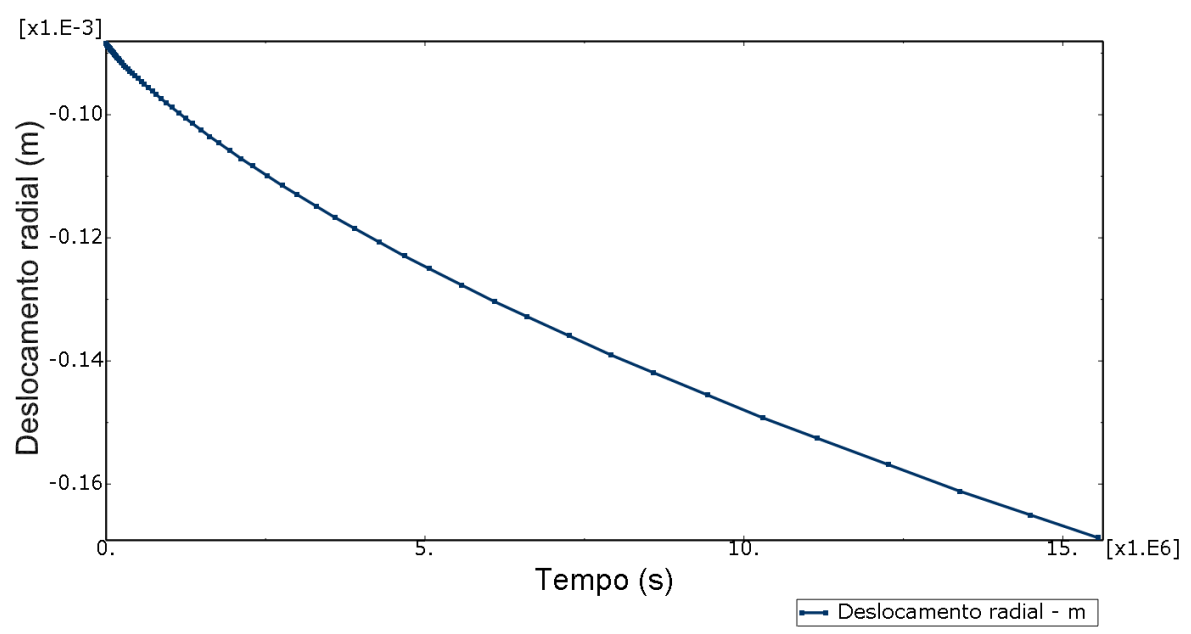

Figura 5.6: Deslocamento da parede do poço ao longo de 6 meses, na base do sal.

A pressão sofreu um acréscimo de $0.12 \mathrm{MPa}$, que corresponde a um aumento de $0.023 \mathrm{lb} /$ gal no gradiente do peso de fluido, na base do sal. $\mathrm{O}$ volume do anular foi reduzido em $0.016 \mathrm{~m}^{3}$. Para este cenário em específico, o hiato entre o fim da construção e início da produção do poço não alterou de maneira significativa a condição de pressão de volume do anular que contém a rocha salina.

O gráfico da figura 5.7 ilustra as alterações de pressão e volume sofridas pelo anular.

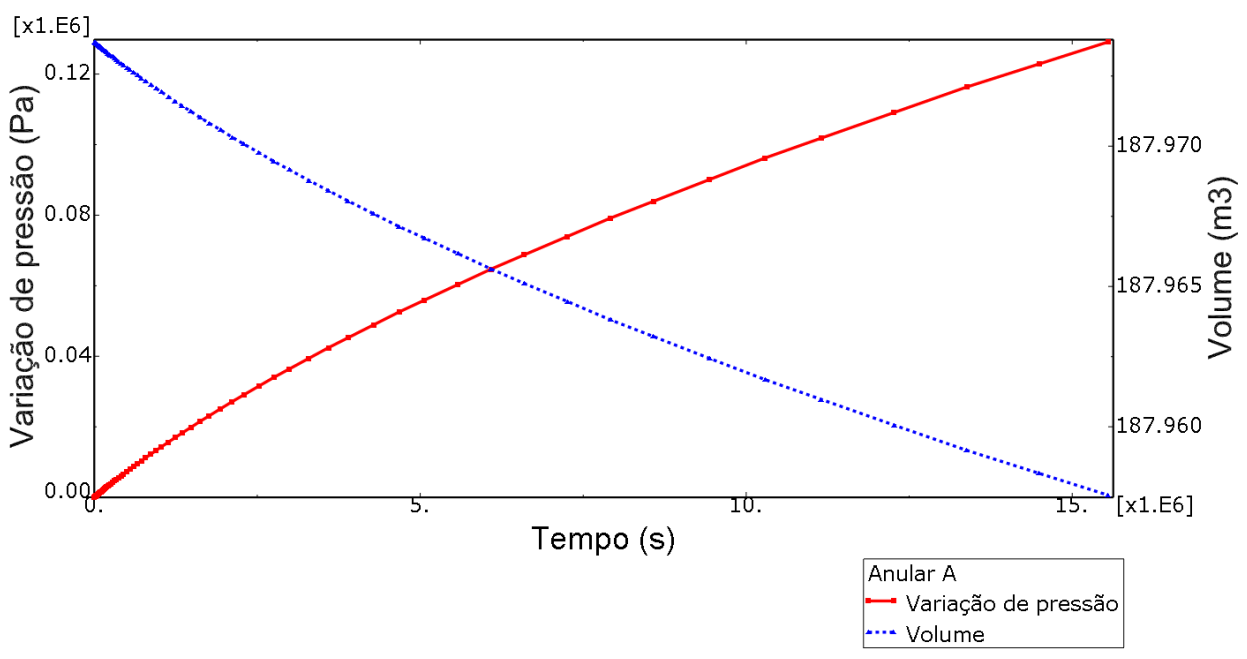

Figura 5.7: Variação volumétrica e de pressão no anular A, durante os 6 meses anteriores ao início da produção.

Com o início da produção se dá o aquecimento do fluido confinado nos espaços anulares e consequentemente o fenômeno de APB. Os perfis térmicos e 
logo as vazões de injeção utilizadas são as mesmas do caso puramente elástico (tabela 5.4).

O gráfico da figura 5.8 apresenta uma comparação da variação de pressão em ambos ao anulares, para o caso puramente elástico e o com o modelo de fluência da rocha salina.

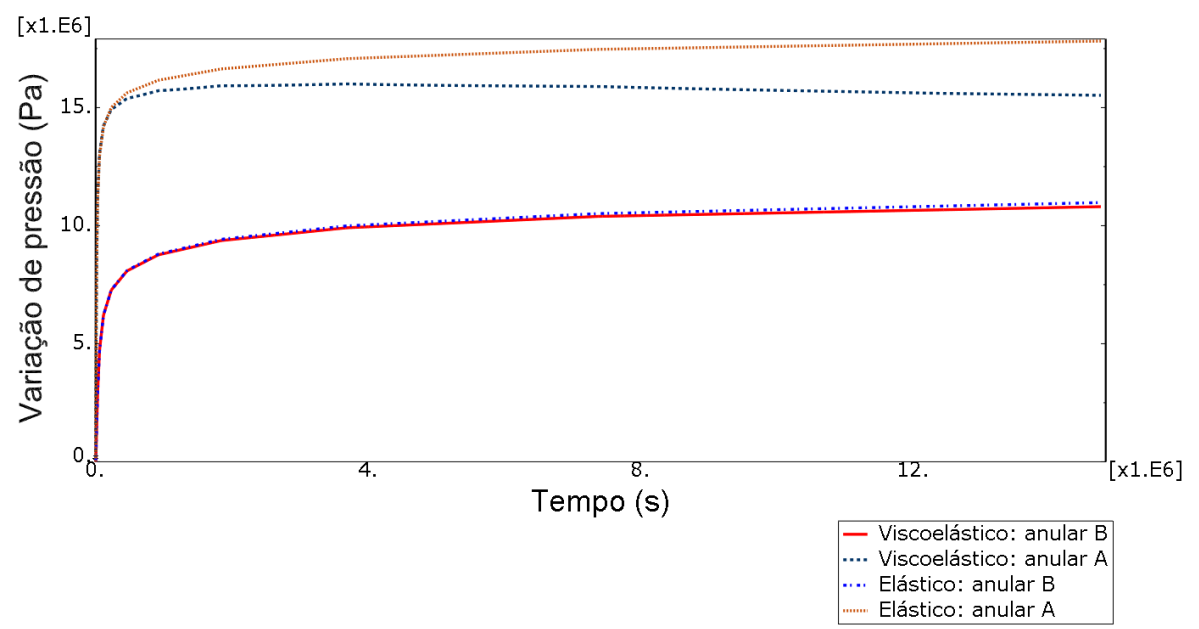

Figura 5.8: Evolução do acréscimo de pressão devido ao fenômeno de APB.

A tabela 5.5 apresenta um resumo dos valores de acréscimo de pressão para os anulares A e B em ambos os modos de simulação, para o caso base.

Tabela 5.5: Variação de pressão para os casos elásticos e considerando comportamento de fluência da rocha salina.

\begin{tabular}{|c|c|c|c|}
\hline & $\Delta P_{\text {Elástico }}[\mathrm{MPa}]$ & $\Delta P_{\text {Viscoelástico }}[\mathrm{MPa}]$ & Diferença \\
\hline Anular A & 17.82 & 16.00 & $10.18 \%$ \\
\hline Anular B & 10.98 & 10.8 & $1.64 \%$ \\
\hline
\end{tabular}

O acréscimo de pressão do anular B para o caso viscoelástico é muito próximo ao caso puramente elástico, apresentando uma redução de 1.64\%. Esta diferença é proveniente da variação de pressão no anular A, visto que as condições do anular B permanecem inalteradas. A pressão do anular A age sobre a superfície interna do revestimento de 20 pol que é o elemento de interface entre ambos anulares. A variação da deformação deste revestimento gera a mudança da pressão do anular B em relação ao caso anterior. No entanto, o revestimento de 20 pol é um elemento de alta rigidez e grande espessura, que pouco se deforma e influencia na pressão do anular B.

Como pode ser observado no gráfico da figura 5.8, o acréscimo de pressão encontrado no segundo caso, no qual o comportamento viscoelástico da rocha salina é considerado, é $10.18 \%$ menor em relação ao caso puramente elástico. 
A rocha salina neste caso, age como um aliviador de pressão, gerando assim um acréscimo máximo de pressão, inferior ao caso elástico.

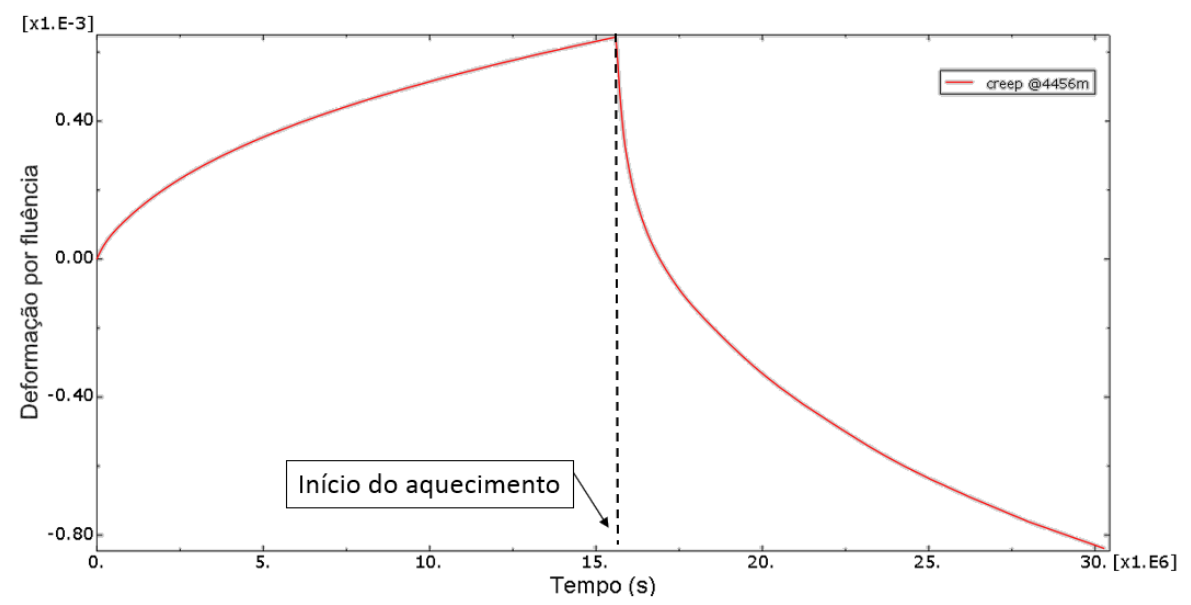

Figura 5.9: Deformação por fluência durante o período total de simulação, para a profundidade de $4456 \mathrm{~m}$.

O gráfico da figura 5.9 apresenta a deformação de fluência de um ponto da parede do poço, na base do sal $(4456 \mathrm{~m})$. Como pode ser observado, a deformação de fluência durante o período inicial está no sentido de redução do diâmetro do poço e consequentemente do volume do espaço anular. A partir do início da expansão térmica, o aumento de pressão no anular A inverte a tendência de deformação por fluência que passa a ser no sentido de aumento do diâmetro do poço e consequentemente acréscimo do volume anular. Parte do acréscimo de pressão que seria gerado pela restrição à expansão térmica é aliviado por este aumento volumétrico do anular e a pressão máxima resultante é inferior ao caso no qual este comportamento não é considerado.

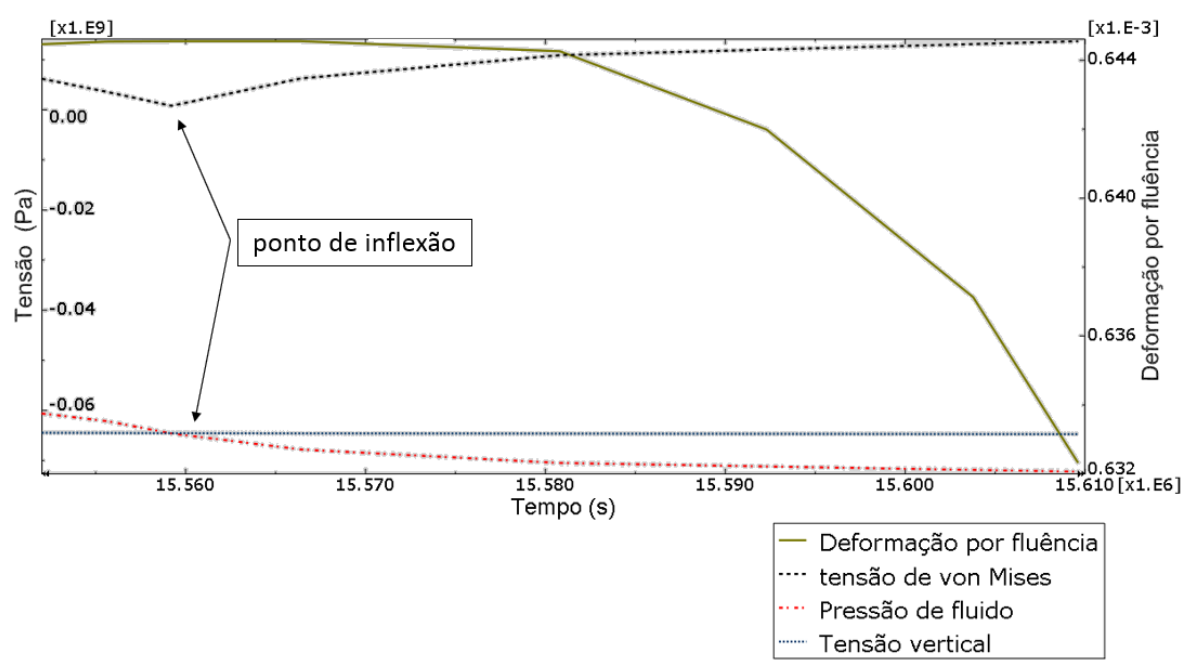

Figura 5.10: Ampliação, durante as primeiras 16 horas do início do aquecimento, da tensão e deformação por fluência. 
O gráfico da figura 5.10 é um zoom do estado de tensão e deformação elástica de fluência durante as primeiras 16 horas do aquecimento do poço para o mesmo ponto analisado acima, de forma a apresentar a inversão de direção de deformação de fluência, visto que no gráfico com o tempo total de simulação torna difícil a visualização de um curto tempo de simulação.

Inicialmente a pressão de fluido é inferior à tensão de sobrecarga (vertical). À medida que o aquecimento do fluido no anular se desenvolve, a pressão gerada pela expansão térmica é suficiente para a tensão radial ultrapassar a tensão vertical. Este ponto é representado pela inflexão na curva da tensão de von Mises. A partir deste então a deformação de fluência aumenta o volume do anular e age como aliviador da pressão de APB.

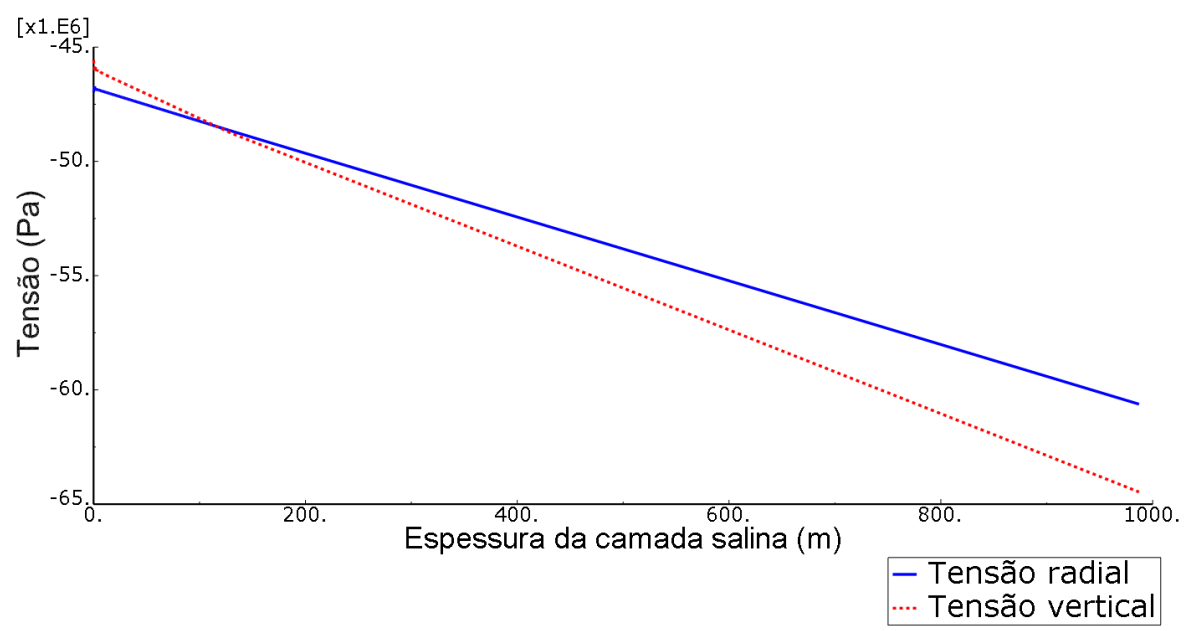

Figura 5.11: Tensões em pontos localizados ao longo da parede do poço no instante do início da produção.

Este processo ocorre em toda a extensão da rocha salina, porém com diferentes intensidades ao longo da profundidade. O ponto da base do anular, exemplificado anteriormente, possui o maior diferencial de tensões iniciais e portanto maior nível de deformações de fluência no período anterior ao início da produção (primeiros 6 meses de simulação). Ou seja, os pontos superiores invertem a direção da deformação elástica de fluência antes e contribuem mais com o alívio da pressão gerada pelo fenômeno de APB. O gráfico da figura 5.11 apresenta as tensões na parede do poço ao longo da camada da rocha salina.

\section{2}

\section{Sal de alta mobilidade}

Na seção anterior foi simulado o caso base de um poço padrão, no qual a formação salina foi considerada composta exclusivamente de halita. Em um poço de petróleo há a presença de diversas rochas ao longo da coluna 
litológica. No caso de formações salinas, há a presença de lentes de sais de maior mobilidade, como por exemplo a carnalita que possui mobilidade aproximadamente 100 vezes superior a halita.

Com o intuito de analisar a presença de sais móveis no trecho de sal, foi incluída a carnalita na modelagem numérica. Foi considerada a proporção de $2 \%$ de sais móveis, que para este caso corresponde a aproximadamente 30 metros. O pacote de carnalita foi condensado no topo da camada salina, entre as profundidades de $3459 \mathrm{~m}$ e $3489 \mathrm{~m}$, conforme ilustrado na figura 5.12 .

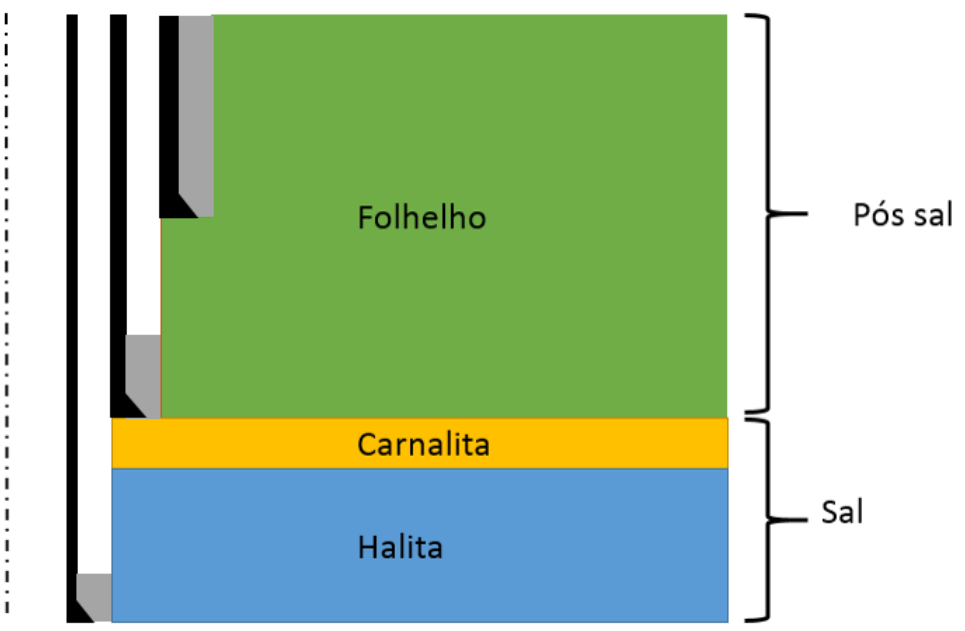

Figura 5.12: Representação do pacote de carnalita no modelo numérico.

A configuração do poço padrão, com sua geometria, estado de tensão, temperatura e pesos de fluido utilizados para a perfuração é a mesma do caso base anterior. Apenas é incluída a lente de carnalita no topo do extrato de sal. Os valores das vazões de injeção utilizados ao longo da simulação sãos os mesmos da tabela 5.4.

Da mesma forma que no caso base, a condição de pressão e volume do anular A não se altera de maneira significativa durante o período inicial de 6 meses. O volume do anular A sofreu uma redução de $0.01 \mathrm{~m}^{3}$ e a pressão um acréscimo de 0.09 MPa. A figura 5.13 ilustra o comportamento do fluido no anular neste período. 


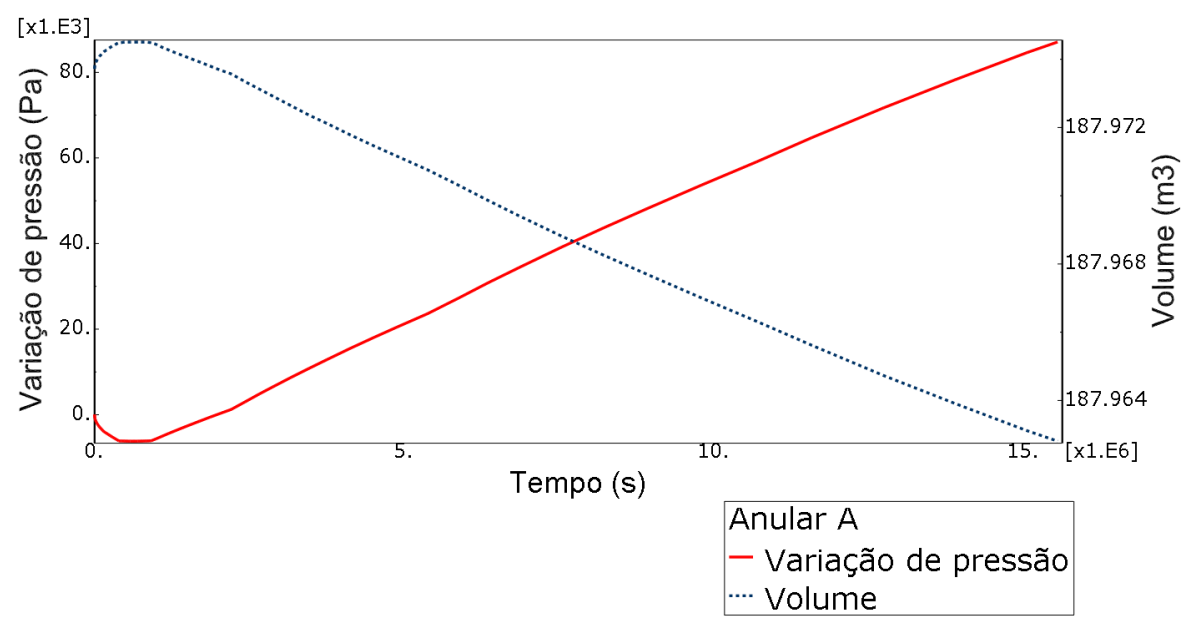

Figura 5.13: Variação de pressão e volume do anular A durante o período de 6 meses até o início da produção, para o caso com lente de carnalita.

No gráfico da figura 5.13 é possível notar que a pressão cai ligeiramente no início do período de 6 meses. Este comportamento se dá pela rápida abertura da lente de carnalita, visto que o pressão gerada nas paredes do poço pelo fluido de perfuração é superior ao estado de tensão in-situ da rocha. Este estado inicial gera concentração de tensão na borda do poço que leva a deformações de fluência no sentido de aumento do diâmetro do poço. No entanto, a concentração de tensão na borda do poço é rapidamente aliviada, como pode ser visto pelo decaimento da tensão de von Mises no gráfico da figura 5.14 .

Em seguida o efeito da rápida abertura da carnalita é estabilizado e a pressão do anular A tende a aumentar pela diminuição do volume anular, gerado pelas deformações de fluência ao longo da fase como um todo. 


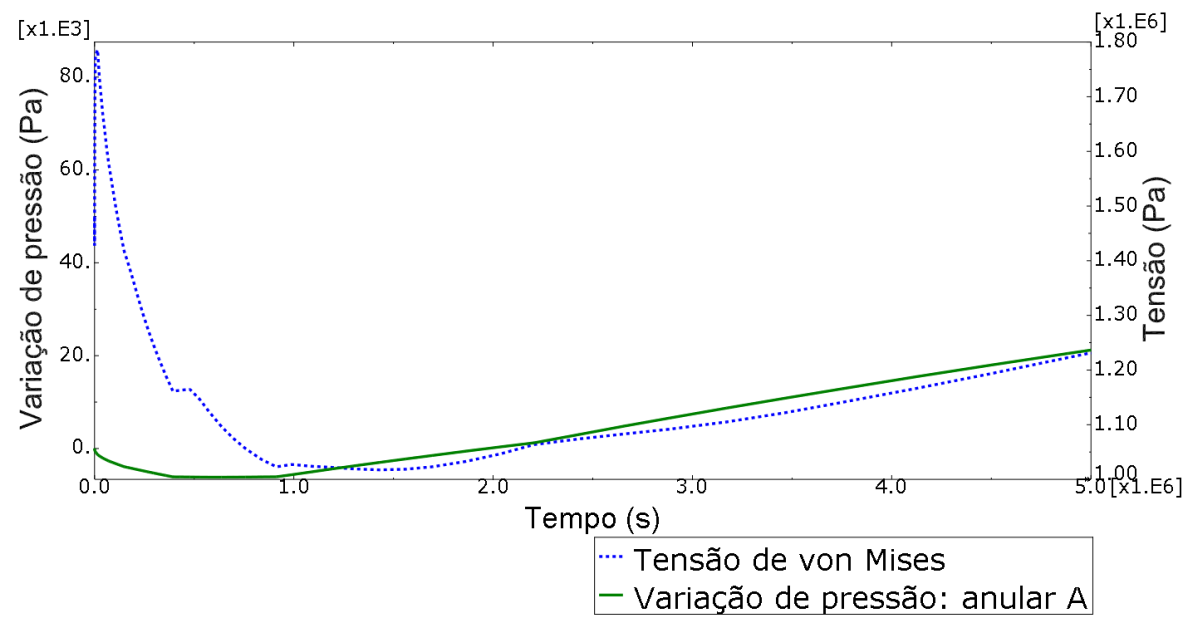

Figura 5.14: Comportamento da tensão de Mises para um ponto a $3459 \mathrm{~m}$ (topo da carnalita) e da pressão do anular A, nos dois primeiros meses de simulação.

O acréscimo de pressão devido ao fenômeno de APB é menor no caso com a presença da lente de carnalita, que representa um sal de alta mobilidade, em relação ao caso base com apenas halita.

O processo de alívio de pressão devido ao aumento do volume do espaço anular observado no caso base, é potencializado pela presença da carnalita que possui uma mobilidade mais alta. O comportamento observado no caso anterior (apenas halita) se repete, no entanto os deslocamentos resultantes das deformações por fluência são maiores na carnalita, em comparação com a halita.

O gráfico da figura 5.15 apresenta o deslocamento radial de um ponto da parede do poço a $3469 \mathrm{~m}$ para ambos os casos de simulação, durante o período de produção do poço. No caso da carnalita este ponto obteve um deslocamento de $1.02 \mathrm{~cm}$ e para o caso com halita o deslocamento foi de $0.81 \mathrm{~mm}$. 


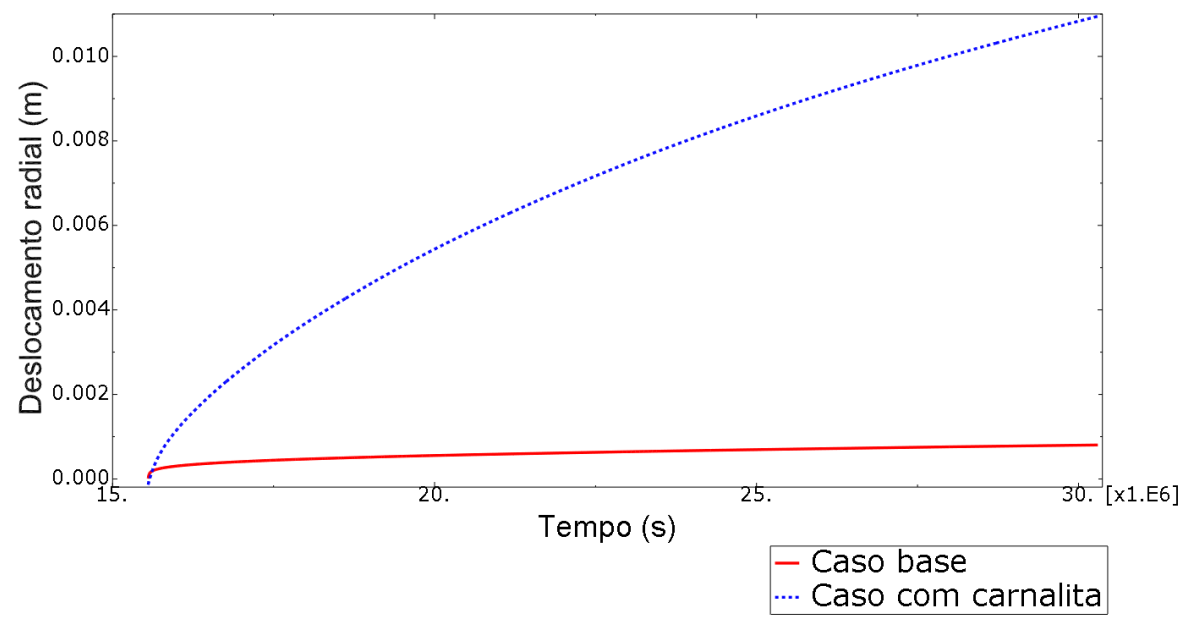

Figura 5.15: Deslocamento da parede do poço para um ponto a $3469 \mathrm{~m}$, na carnalita.

O resultado final é um menor acréscimo máximo de pressão. A figura 5.16 apresenta a evolução das pressões ao longo do período de produção dos anulares A e B para ambos os casos, base e com lente de carnalita.

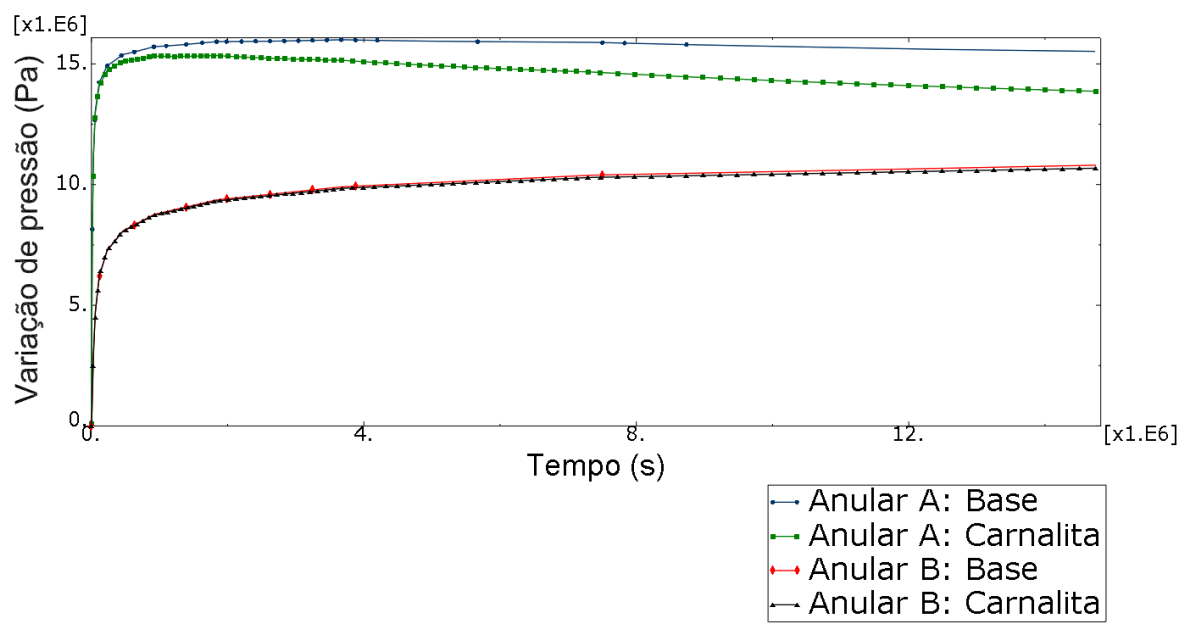

Figura 5.16: Comparação do crescimento de pressão em ambos anulares para o caso base e com a presença da lente de carnalita.

A tabela 5.6 apresenta a comparação entre os valores de pico de pressão para ambos os casos.

Tabela 5.6: Variação máxima de pressão para os casos base e com presença de lente de carnalita.

\begin{tabular}{|l|c|c|c|}
\hline & $\Delta P_{\text {base }}[\mathrm{MPa}]$ & $\Delta P_{\text {carnalita }}[\mathrm{MPa}]$ & Diferença \\
\hline Anular A & 16.00 & 15.35 & $4.09 \%$ \\
\hline Anular B & 10.81 & 10.68 & $1.15 \%$ \\
\hline
\end{tabular}


O anular B, da mesma forma que na simulação viscoelástica anterior, se mostra pouco sensível a variações de pressão ocorridas no anular A.

\section{3}

\section{Efeito do peso de fluido}

Nesta seção é investigada a influência do peso de fluido utilizado para a perfuração da fase salina no acréscimo de pressão anular, visto que o peso de fluido influencia diretamente no estado de tensão do poço e consequentemente no nível da tensão de von Mises. Por sua vez, o fenômeno de fluência da rocha salina tem seu comportamento relacionado diretamente com a tensão de von Mises, segundo o modelo de fluência de duplo mecanismo utilizado.

Logo, afim de atingir este objetivo, foram analisados 3 cenários distintos, sendo um deles o caso base previamente simulado, para fins de comparação. No caso base foi utilizado para a perfuração da fase salina fluido de perfuração de peso 11.5 ppg. Adicionalmente foram simulados mais dois casos, com fluidos de peso 9 ppg e 13 ppg, de forma a representar casos de escolha de fluidos leve e pesado respectivamente. Tais pesos de fluido representam condições extremas para o poço em estudo.

O gráfico da figura 5.17 ilustra a variação da tensão de von Mises ao longo da fase do sal, para os diferentes pesos de fluido simulados, imediatamente após o término da perfuração do poço. Conforme pode se notar, há uma grande diferença na tensão de von Mises ao longo da fase salina para os diferentes cenários simulados. Na base do sal, onde o gradiente de sobrecarga é de 12.89 ppg, para o cenário de perfuração com o fluido de peso 13 ppg que se aproxima ao estado de tensão in-situ da rocha, a tensão de von Mises é de 1.09 MPa. No outro extremo, para o cenário de perfuração com fluido leve de 9 ppg a tensão de von Mises na base do sal é de $31.31 \mathrm{MPa}$. A tensão de von Mises influencia na taxa da deformação de fluência, o que acarretará diferentes níveis de deformações por fluência e consequentemente na resposta final do sistema, no que tange o alívio de pressão pelo sal. 


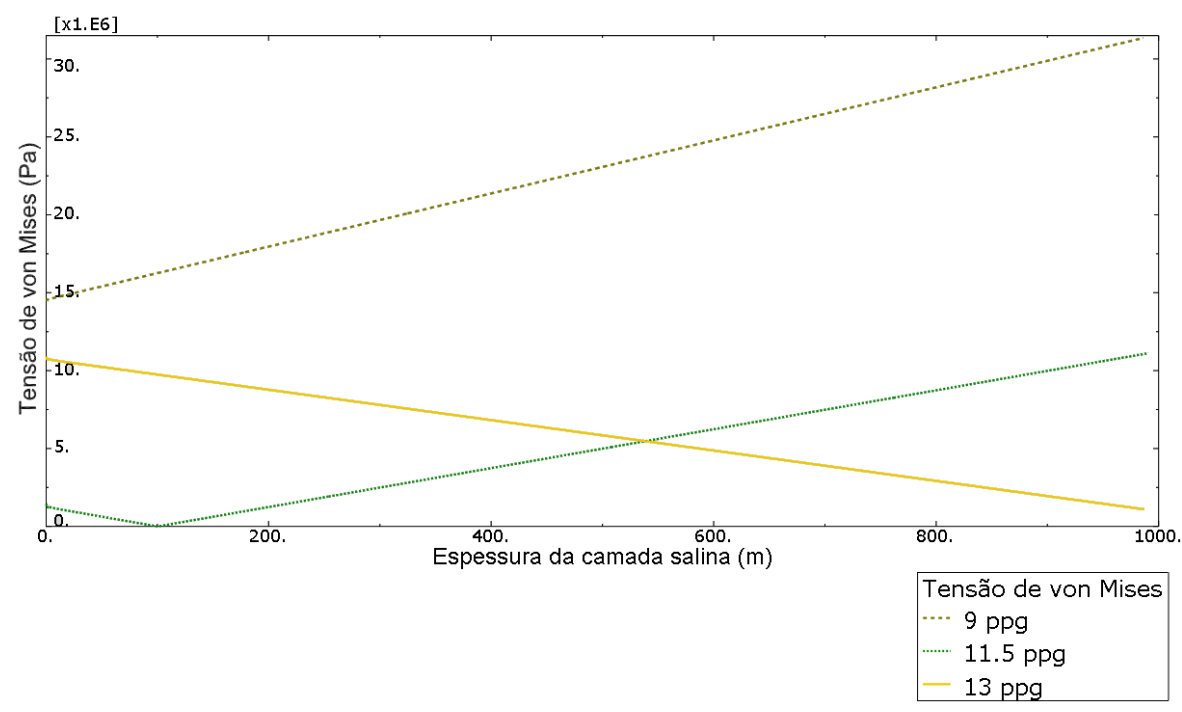

Figura 5.17: Tensão de von Mises na parede do poço ao longo da fase do sal, para os diferentes casos de peso de fluido, imediatamente após a perfuração.

Em seguida, é simulado o período de 6 meses que precede o início da produção do poço. O gráfico da figura 5.18 apresenta a variação de pressão do anular A, durante este intervalo de tempo.

Para o caso do fluido leve houve uma pressurização do anular no valor máximo de $3 \mathrm{MPa}$, que corresponde a aproximadamente 0.75 ppg na profundidade da sapata do revestimento de 20 pol. Este acréscimo de pressão é devido ao acentuado fechamento das paredes do poço, derivado de um baixo peso de fluido utilizado, que gera uma pressão de suporte pequena em comparação com o estado de tensão in-situ do sal.

No caso da utilização de um fluido pesado de 13 ppg praticamente não há alteração de pressão no anular. A pressão gerada pelo fluido de perfuração se aproxima ao estado de tensão in-situ da rocha. 


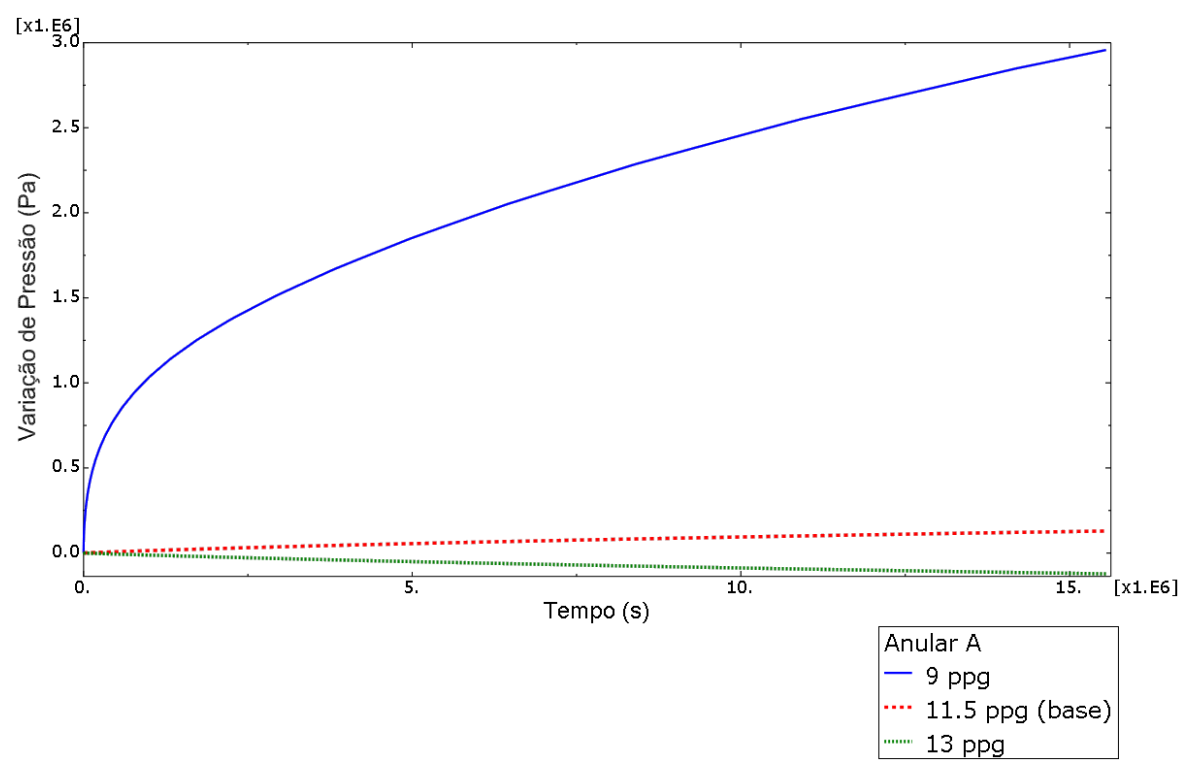

Figura 5.18: Variação de pressão do anular A no período inicial de 6 meses para os casos de fluido leve e pesado.

Os parâmetros térmicos e de produção do poço, como vazão de óleo, temperatura inicial (gradiente geotérmico) e perfis térmicos ao longo do tempo, calculados pelo Wellcat, permanecem os mesmos do caso base anteriormente definidos. No entanto, devido ao artifício numérico adotado na presente metodologia utilizar injeção de massa no anular, as vazões mássicas devem ser corrigidas uma vez que as densidades dos fluidos foram modificadas.

As tabelas 5.7 e 5.8 abaixo, apresentam os valores de vazões utilizadas nas simulações de peso leve e pesado respectivamente. 
Tabela 5.7: Expansão volumétrica para o caso de fluido leve (9 ppg).

\begin{tabular}{|l|c|c|c|c|}
\hline & $\Delta m_{A}[\mathrm{~kg}]$ & $\Delta m_{B}[\mathrm{~kg}]$ & $Q_{A}\left[10^{-6} \mathrm{~kg} / \mathrm{s}\right]$ & $Q_{B}\left[10^{-6} \mathrm{~kg} / \mathrm{s}\right]$ \\
\hline $\mathbf{1 h}$ & 302.29 & 1.98 & 83968.08 & 550.16 \\
\hline $\mathbf{2 h}$ & 493.95 & 20.85 & 137208.38 & 5792.64 \\
\hline $\mathbf{4 h}$ & 637.32 & 109.33 & 88516.05 & 15184.74 \\
\hline $\mathbf{8 h}$ & 524.13 & 266.13 & 36397.73 & 18481.22 \\
\hline $\mathbf{1 6 h}$ & 325.77 & 333.09 & 11311.52 & 11565.70 \\
\hline $\mathbf{3 2 h}$ & 203.54 & 278.43 & 3533.65 & 4833.85 \\
\hline $\mathbf{6 4 h}$ & 132.54 & 199.68 & 1150.49 & 1733.34 \\
\hline $\mathbf{1 2 8 h}$ & 101.80 & 152.81 & 441.84 & 663.24 \\
\hline $\mathbf{2 5 6 h}$ & 87.13 & 130.14 & 189.09 & 282.43 \\
\hline $\mathbf{5 1 2 h}$ & 78.30 & 116.51 & 84.96 & 126.42 \\
\hline $\mathbf{1 0 2 4 h}$ & 71.35 & 106.20 & 38.71 & 57.62 \\
\hline $\mathbf{2 0 4 8 h}$ & 64.60 & 97.21 & 17.52 & 26.37 \\
\hline $\mathbf{4 0 9 6 h}$ & 57.38 & 87.23 & 7.78 & 11.83 \\
\hline
\end{tabular}

Tabela 5.8: Expansão volumétrica para o caso de fluido pesado (13 ppg).

\begin{tabular}{|l|c|c|c|c|}
\hline & $\Delta m_{A}[\mathrm{~kg}]$ & $\Delta m_{B}[\mathrm{~kg}]$ & $Q_{A}\left[10^{-6} \mathrm{~kg} / \mathrm{s}\right]$ & $Q_{B}\left[10^{-6} \mathrm{~kg} / \mathrm{s}\right]$ \\
\hline $\mathbf{1 h}$ & 436.63 & 1.98 & 121287.23 & 550.16 \\
\hline $\mathbf{2 h}$ & 713.48 & 20.85 & 198189.88 & 5792.64 \\
\hline $\mathbf{4 h}$ & 920.57 & 109.33 & 127856.51 & 15184.74 \\
\hline $\mathbf{8 h}$ & 757.07 & 266.13 & 52574.51 & 18481.22 \\
\hline $\mathbf{1 6 h}$ & 470.56 & 333.09 & 16338.87 & 11565.70 \\
\hline $\mathbf{3 2 h}$ & 294.00 & 278.43 & 5104.16 & 4833.85 \\
\hline $\mathbf{6 4 h}$ & 191.44 & 199.68 & 1661.81 & 1733.34 \\
\hline $\mathbf{1 2 8 h}$ & 147.04 & 152.81 & 638.21 & 663.24 \\
\hline $\mathbf{2 5 6 h}$ & 125.86 & 130.14 & 273.14 & 282.43 \\
\hline $\mathbf{5 1 2 h}$ & 113.09 & 116.51 & 122.71 & 126.42 \\
\hline $\mathbf{1 0 2 4 h}$ & 103.07 & 106.20 & 55.92 & 57.62 \\
\hline $\mathbf{2 0 4 8 h}$ & 93.31 & 97.21 & 25.31 & 26.37 \\
\hline $\mathbf{4 0 9 6 h}$ & 82.89 & 87.23 & 11.24 & 11.83 \\
\hline
\end{tabular}

O gráfico da figura 5.19 apresenta a evolução da pressão ao longo das simulações para os diferentes pesos de fluido utilizados. O anular B não sofre influência significativa em sua pressurização, em resposta a alteração do peso de fluido utilizado para a perfuração da fase salina. 


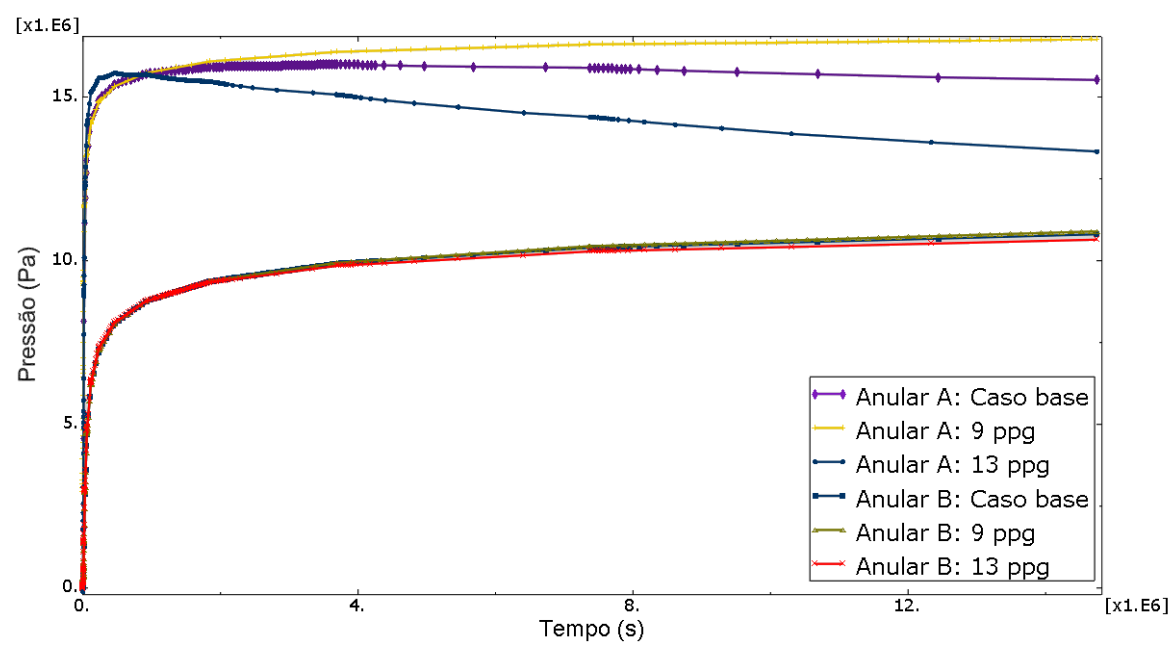

Figura 5.19: Acréscimo de pressão dos anulares A e B para os casos com pesos de fluido distintos.

No anular A o caso que apresenta o maior acréscimo de pressão é o que utiliza fluido de peso 9 ppg e o de menor acréscimo de pressão é o caso do fluido de 13 ppg de peso. O acréscimo máximo de pressão apresenta uma relação inversamente proporcional ao peso de fluido utilizado durante a perfuração da fase salina.

Tal comportamento é devido aos respectivos níveis de alívio de pressão pela abertura das paredes do poço por deformação de fluência. Quanto maior o peso de fluido utilizado menor é tensão de von Mises na parede do poço (figura 5.17), logo o acréscimo de pressão pela expansão térmica necessário para que o poço se deforme no sentido de aumentar o diâmetro é menor.

O gráfico da figura 5.20 mostra uma ampliação no estado de tensões na parede do poço para a base do sal, nas 16 primeiras horas do aquecimento. Para o caso de 9 ppg a tensão de von Mises decai enquanto o acréscimo de pressão gerado pelo aquecimento eleva a tensão na parede do poço para o valor da tensão in-situ(estado hidrostático de tensões). A partir deste ponto a tensão de von Mises torna a aumentar e em seguida a deformação de fluência passa a agir no sentido de aumentar o diâmetro do poço. Este mesmo comportamento ocorre para o caso base de 11.5 ppg, porém a inversão de comportamento ocorre antes, com um menor acréscimo de pressão. Para o caso de 13 ppg, no qual a pressão gerada pelo fluido é inicialmente maior que a tensão in-situ (gradiente de sobrecarga de 12.89 ppg), o acréscimo de pressão gerado pelo aquecimento aumenta desde o início a tensão de von Mises que gera deformações de fluência no sentido de abrir o poço. O gráfico da figura 5.21 ilustra a tensão de von Mises para os demais casos. 


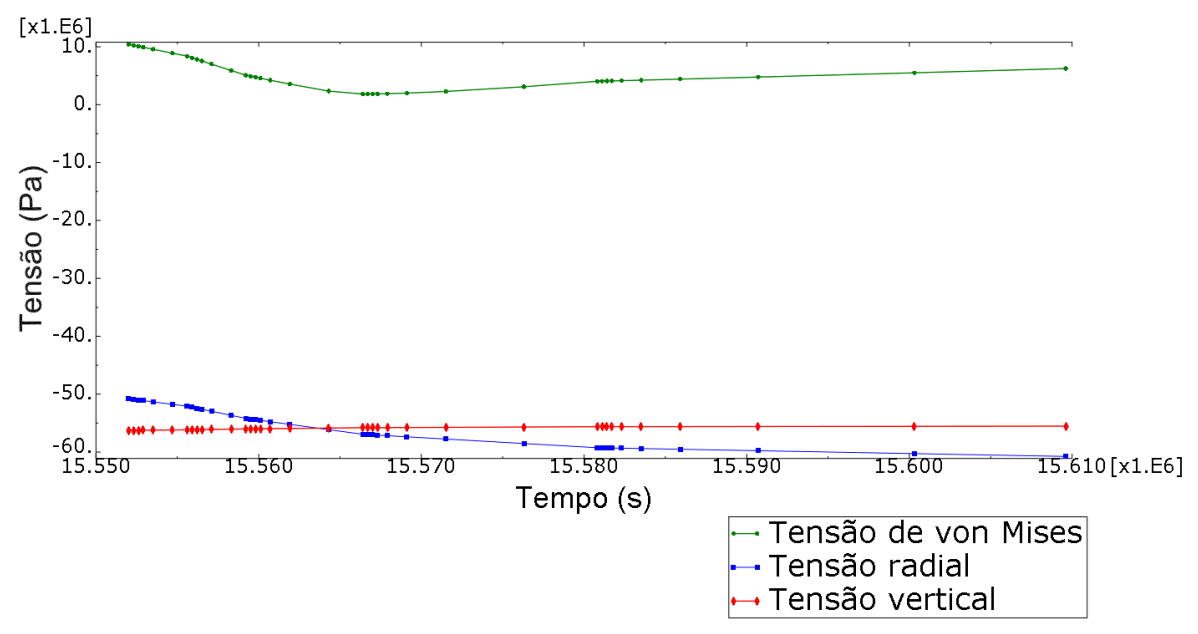

Figura 5.20: Tensões na parede do poço a $4456 \mathrm{~m}$ para o caso de 9 ppg, durante as 16 primeiras horas de produção.

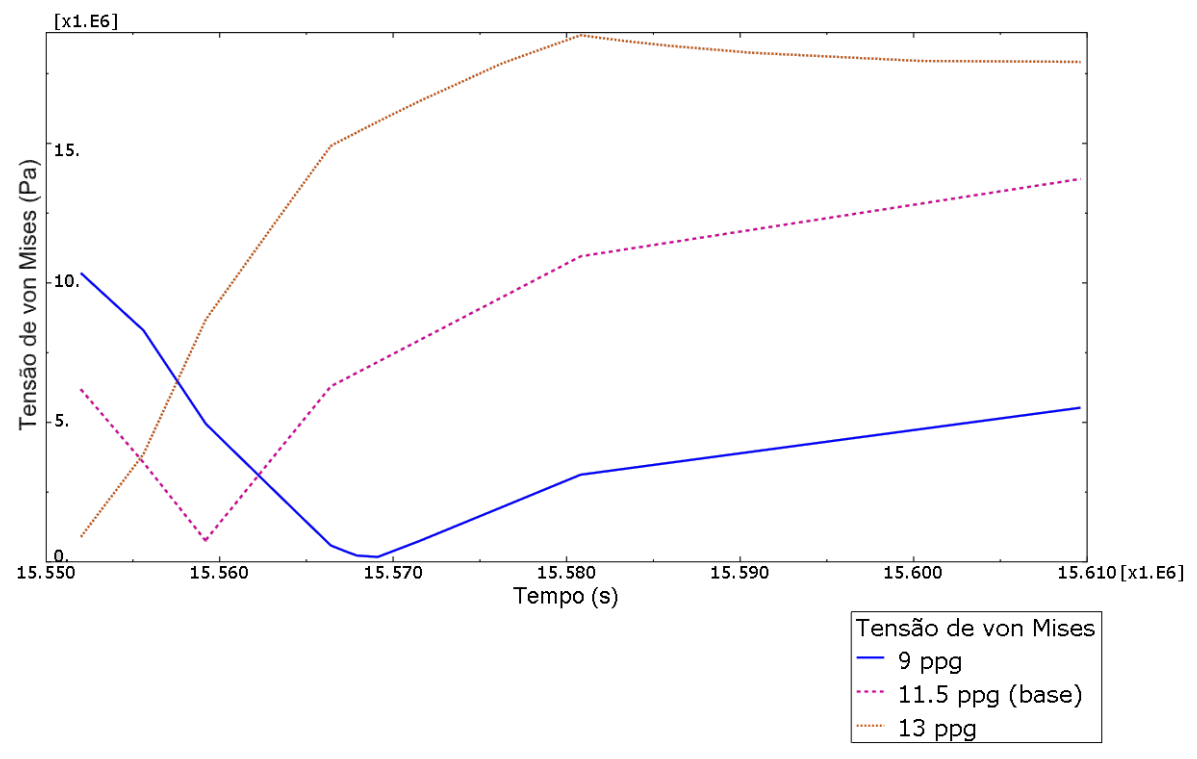

Figura 5.21: Tensão de von Mises para as 16 h iniciais de produção.

\section{4}

\section{Poços de alta temperatura}

Na região do pré-sal são encontrados poços com diferentes níveis de temperatura, tanto da rocha salina quanto do óleo do reservatório. A temperatura é variável de suma importância no fenômeno de APB, influenciando diretamente na expansão térmica do fluido de perfuração confinado nos anulares e consequentemente na evolução da pressão com o tempo. Além disso, em poços com presença de rocha salina, a fluência é dependente da temperatura, conforme apresentado na equação 2-6. 
Para o mesma configuração de poço, apenas com a temperatura mais elevada, o acréscimo de pressão gerado pelo fenômeno de APB tende a ser maior. No entanto, como observado em casos simulados anteriormente, a rocha salina pode agir como aliviador dessa pressão. O aumento de temperatura também aumenta o nível de deformação de fluência para o mesmo estado de tensões (tensão de von Mises), por um fator multiplicativo exponencial. Logo, o alívio desse acréscimo de pressão pode ser potencialmente mais elevado.

A partir da equação que define a taxa de deformação por fluência, podese encontrar a relação entre as taxas de fluência para diferentes temperaturas, para a mesma tensão de von Mises, dividindo uma equação por outra. A equação 5-1 representa a relação entre as taxas de deformação para duas temperaturas $T_{1}$ e $T_{2}$.

$$
\frac{\left(\dot{\epsilon_{0}}\right)_{T 1}}{\left(\dot{\epsilon_{0}}\right)_{T 2}}=e^{-\frac{Q}{R}\left(\frac{T_{1}-T_{2}}{T_{1} T_{2}}\right)}
$$

Afim de investigar o efeito da temperatura no fenômeno de APB para poços com presença de rocha salina, foi simulado um caso de temperatura mais elevada. Foi utilizado um incremento de $50 \%$ em relação as condições do poço padrão, como o perfil térmico inicial (gradiente geotérmico) e temperatura do óleo no reservatório. No topo do sal a temperatura é de $71.18^{\circ} \mathrm{C}$, na base do sal de $91.47{ }^{\circ} \mathrm{C}$ e óleo do reservatório a $95.31{ }^{\circ} \mathrm{C}$. Substituindo os valores das constantes e dos valores de temperatura na equação 5-1 temos uma diferença de $267 \%$ e $354 \%$ na taxa de deformação por fluência entre os casos base e de alta temperatura, para o topo e a base do sal respectivamente.

Durante o período de 6 meses anteriores ao início da produção a pressão do anular A não sofreu variação significativa, da mesma forma que em casos simulados anteriormente. Houve um acréscimo de pressão de $0.32 \mathrm{MPa}$ ao final deste período, conforme mostra o gráfico da figura 5.22. 


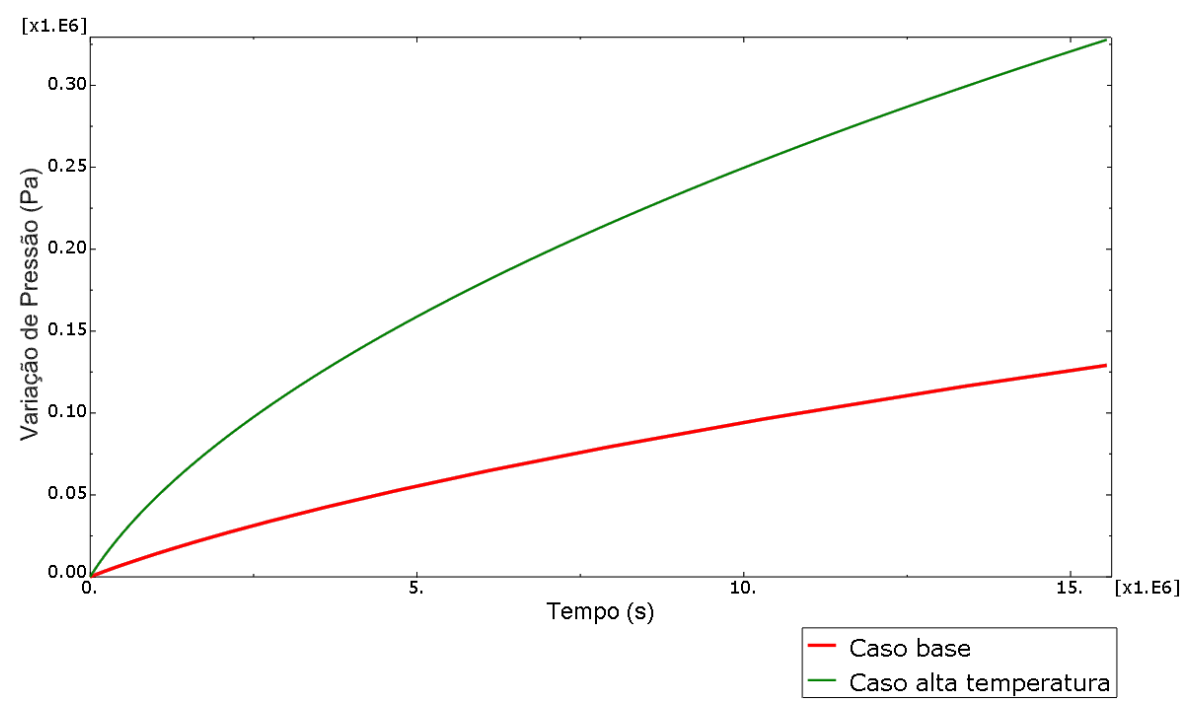

Figura 5.22: Variação de pressão do anular A durante os 6 meses anteriores a produção, para o caso base e de alta temperatura.

Este acréscimo de pressão de $0.32 \mathrm{MPa}$, embora pequeno, é $266 \%$ maior em relação ao caso base que apresentou uma pressurização de 0.12 MPa. Essa diferença se dá pelo maior nível de fechamento do poço pela fluência do sal no caso de alta temperatura, visto que as demais condições são semelhantes. O gráfico da figura 5.23 apresenta o deslocamento da parede do poço para a profundidade de $4456 \mathrm{~m}$. O poço apreentou um fechamento de $2.94 \times 10^{-4} \mathrm{~m}$, que é $75 \%$ maior que os $1.69 \times 10^{-4} \mathrm{~m}$ do caso base.

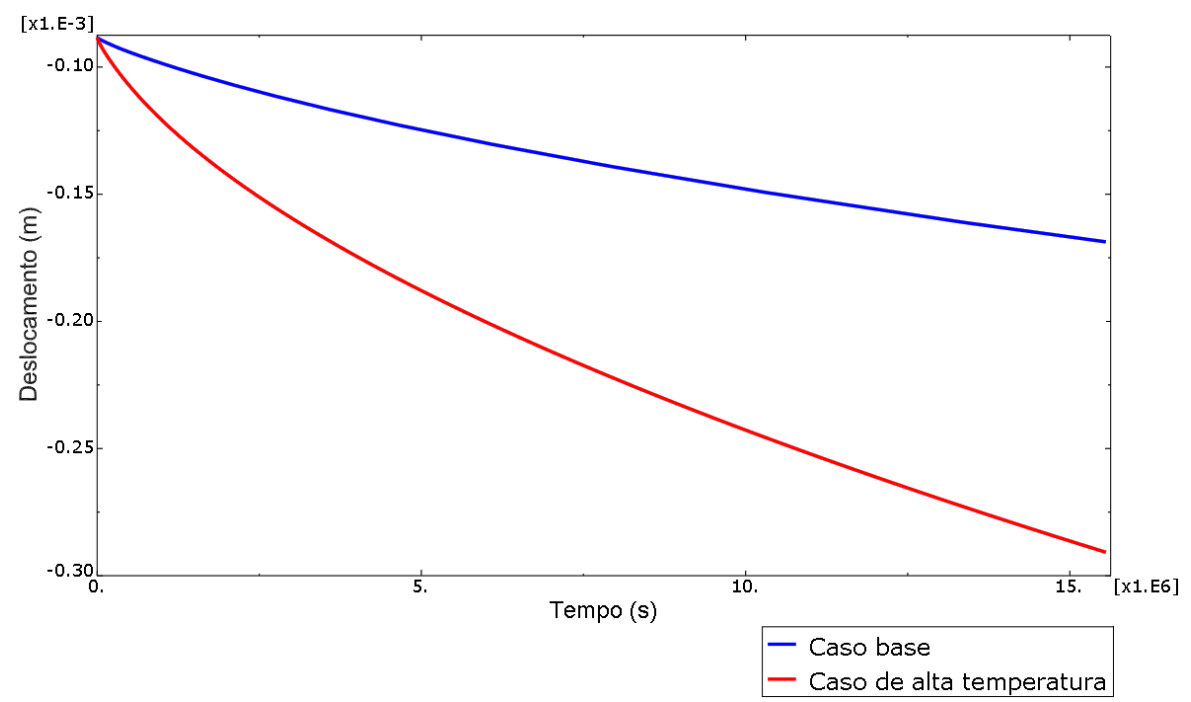

Figura 5.23: Deslocamento radial da parede do poço, para a profundidade de $4456 \mathrm{~m}$.

Devido a nova condição inicial de temperatura, os perfis térmicos ao longo do tempo e consequentemente as expansões mássicas e correspondentes vazões 
de injeção foram recalculadas. A tabela 5.9 apresenta as expansões e vazões mássicas utilizadas no caso de alta temperatura.

Tabela 5.9: Expansão volumétrica para o caso de alta temperatura.

\begin{tabular}{|l|c|c|c|c|}
\hline & $\Delta m_{A}[\mathrm{~kg}]$ & $\Delta m_{B}[\mathrm{~kg}]$ & $Q_{A}\left[10^{-6} \mathrm{~kg} / \mathrm{s}\right]$ & $Q_{B}\left[10^{-6} \mathrm{~kg} / \mathrm{s}\right]$ \\
\hline $\mathbf{1 h}$ & 259.32 & 4.39 & 72033.54 & 1218.14 \\
\hline $\mathbf{2 h}$ & 808.61 & 39.67 & 224613.54 & 11019.60 \\
\hline $\mathbf{4 h}$ & 1165.82 & 196.00 & 161919.04 & 27221.62 \\
\hline $\mathbf{8 h}$ & 942.26 & 451.61 & 65434.47 & 31361.76 \\
\hline $\mathbf{1 6 h}$ & 565.93 & 543.70 & 19650.45 & 18878.52 \\
\hline $\mathbf{3 2 h}$ & 334.02 & 444.78 & 5798.98 & 7721.82 \\
\hline $\mathbf{6 4 h}$ & 211.67 & 319.98 & 1837.42 & 2777.64 \\
\hline $\mathbf{1 2 8 h}$ & 158.34 & 247.41 & 687.26 & 1073.82 \\
\hline $\mathbf{2 5 6 h}$ & 135.90 & 211.38 & 294.92 & 458.71 \\
\hline $\mathbf{5 1 2 h}$ & 121.95 & 189.66 & 132.32 & 205.79 \\
\hline $\mathbf{1 0 2 4 h}$ & 110.69 & 171.78 & 60.05 & 93.20 \\
\hline $\mathbf{2 0 4 8 h}$ & 101.11 & 157.47 & 27.43 & 42.72 \\
\hline $\mathbf{4 0 9 6 h}$ & 91.21 & 140.04 & 12.37 & 18.99 \\
\hline
\end{tabular}

O acréscimo máximo de pressão para o caso de alta temperatura é de 18.89 $\mathrm{MPa}$, o que representa um aumento de $18.05 \%$ em relação ao caso base. Embora a temperatura tenha sido aumentada em $50 \%$, o que gera uma expansão volumétrica $50 \%$ maior segundo o modelo de fluido utilizado, o acréscimo de pressão não aumenta na mesma proporção. Esse comportamento se deve ao fato da temperatura aumentar o nível de fluência da rocha salina, que tem seu efeito de alívio de pressão potencializado. 


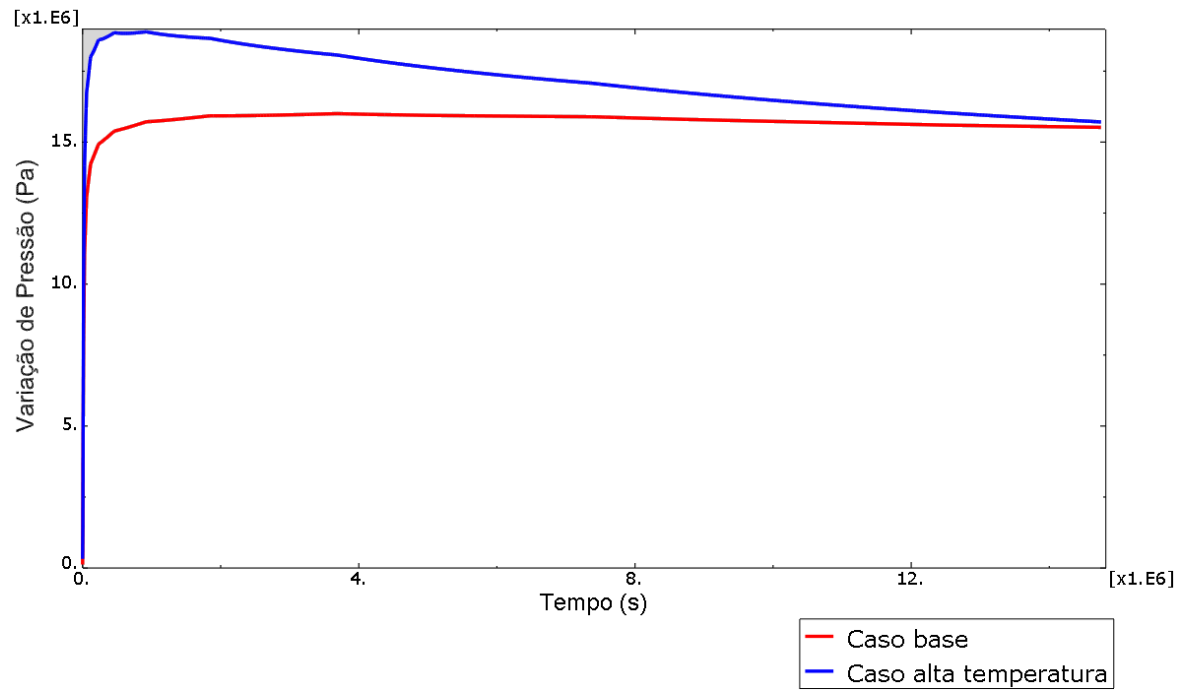

Figura 5.24: Acréscimo de pressão durante a produção do poço para o caso base e de alta temperatura.

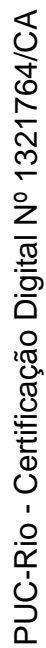




\section{Conclusão}

\section{1}

\section{Considerações gerais}

O fenômeno de APB gera um acréscimo de pressão nos anulares do poço, podendo este ser de alta magnitude. A correta modelagem do fenômeno é de grande importância, de forma a subsidiar o projeto do poço e o seguro dimensionamento dos componentes mecânicos que devem resistir a este esforço extra, como por exemplo coluna de revestimento e cabeça de poço.

No contexto de poços do Pré-Sal, temos a presença de rochas evaporíticas, que apresentam deformações por fluência e que não são consideradas pelos softwares de referência na modelagem do fenômeno de APB. A deformação por fluência altera o volume do espaço anular, que influencia diretamente no acréscimo de pressão oriundo da expansão térmica, fruto da produção do poço.

O desenvolvimento de uma metodologia que leve em consideração o comportamento viscoelástico da rocha salina é de grande importância, uma vez que a região do Pré-Sal é extremamente relevante no contexto da indústria de óleo e gás no Brasil. O Pré-Sal atualmente contribui com uma produção de mais de 1 milhão de barris por dia e possui um grande potencial de protagonismo no cenário de E\&P no Brasil para os anos à frente.

\section{2}

\section{Conclusões}

Foi desenvolvido um modelo termo-mecânico axissimétrico utilizando o software de elementos finitos ABAQUS, afim de determinar o acréscimo de pressão gerado pelo fenômeno de APB e investigar a influência da presença da rocha salina.

Para o caso puramente elástico de um poço padrão, sem considerar o comportamento viscoelástico do sal, foi encontrado um acréscimo de pressão de 17.82 MPa e 10.98 MPa para os anulares A e B respectivamente. Quando se considera o comportamento de fluência da rocha salina, os novos picos de pressão dos anulares A e B são respectivamente $16.00 \mathrm{MPa}$ e $10.80 \mathrm{MPa}$, o que representa uma redução de $10.18 \%$ e $1.64 \%$ respectivamente. Neste caso 
o anular B se mostrou pouco sensível ao efeito do sal no anular A. Este comportamento se deve ao fato do revestimento de 20 pol, que é o elemento de ligação entre os dois anulares A e B, ser de grande espessura e alta rigidez. No anular A houve uma redução de $10.18 \%$ no pico de pressão, devido ao alívio promovido pela rocha salina. A expansão térmica gerou um acréscimo de pressão suficiente para que a fluência da rocha salina agisse no sentido de aumento do volume anular, acomodando parte do incremento de pressão gerado pela expansão térmica.

Este comportamento do sal, de alívio de pressão e consequente redução do pico máximo gerado pelo fenômeno de APB, é potencializado no caso que se inclui uma lente de sal de alta mobilidade (carnalita) com espessura de $30 \mathrm{~m}$. Neste cenário a redução em relação ao caso base viscoelástico foi de 4.09\%. A fluência do sal no sentido de aumento do diâmetro do poço é maior na lente de carnalita, que possui taxa de fluência da ordem de 100 vezes superior à halita, contribuindo assim para um maior aumento de volume anular e maior redução de pressão em relação ao caso apenas com halita.

Para o caso onde foram simulados diversos pesos de fluido utilizados para a perfuração da fase do sal, o acréscimo de pressão gerado pelo fenômeno de APB apresentou relação inversamente proporcional ao peso de fluido empregado. Este comportamento é devido aos respectivos níveis de alívio de pressão pela abertura das paredes do poço por deformação de fluência. Quanto maior o peso de fluido utilizado menor é tensão de von Mises na parede do poço, logo o acréscimo de pressão pela expansão térmica necessário para que o poço se deforme no sentido de aumentar o diâmetro é menor.

Por fim, foi analisado um caso de alta temperatura onde o gradiente geotérmico do poço foi aumentado em $50 \%$. O pico de pressão encontrado foi de $18.89 \mathrm{MPa}$, que representa um acréscimo de $18.05 \%$ em relação ao caso base (viscoelástico). Embora a temperatura tenha sido aumentada em $50 \%$, o que gera uma expansão volumétrica $50 \%$ maior segundo o modelo de fluido utilizado, o acréscimo de pressão não aumenta na mesma proporção. A taxa de fluência é potencializada com o aumento da temperatura, para o modelo constitutivo utilizado. Nesse caso o alívio da pressão pela deformação de fluência também é potencializado e consequentemente o aumento de pressão não acompanha proporcionalmente o aumento no gradiente geotérmico.

Conclui-se que a consideração do modelo constitutivo viscoelástico do material salino altera o valor do pico de pressão encontrado devido ao fenômeno de APB.

\section{3}




\section{Sugestões e trabalhos futuros}

O presente trabalho apresenta um modelo numérico no qual foram utilizadas diversas hipóteses simplificadoras. Trabalhos futuros podem ser desenvolvidos de maneira a incrementar o nível de complexidade do modelo e acurácia da resposta do acréscimo de pressão gerado pelo fenômeno de APB.

O modelo de expansão térmica utilizado para o fluido de perfuração considera propriedades de compressibilidade e expansão térmicas constantes. A utilização de um modelo PVT de maior complexidade pode alterar o valor do acréscimo de pressão encontrado durante a produção do poço.

A coluna litológica empregada foi simplificada, considerando materiais puros e com propriedades elásticas constantes ao longo da profundidade. A implementação de uma coluna litológica que contemple as intercalações encontradas num poço de petróleo pode alterar as deformações sofridas pela parede do poço e consequentemente a variação de volume anular, que é variável chave no cálculo da variação de pressão do anular.

A possível fratura do material rochoso não foi considerada. A implementação de um critério de falha pode alterar o pico de pressão encontrado, caso uma fratura se desenvolva ao longo da pressurização do anular e consequentemente fluido seja drenado para a formação, aliviando a pressão. Além disso, outros modelos constitutivos podem ser empregados na descrição do comportamento viscoelástico da rocha salina, considerando os períodos de fluência primária e terciária. 


\section{Referências bibliográficas}

[1] ADMINISTRATION, U. E. I.. Petróleo bruto brent preço diário. http://www.indexmundi.com/pt/pre2016. Acesso em: junho de 2016.

[2] PETROBRAS. Nossa produção de petróleo no pré-sal ultrapassa 1 milhão de barris por dia. http://www. petrobras.com.br/fatos-edados/nossa-producao-de-petroleo-no-pre-sal-ultrapassa-1-milhao-de-barrispor-dia.htm, 2016. Acesso em: jumho de 2016.

[3] PETROBRAS. Pré-sal. http://www.petrobras.com.br/pt/nossasatividades/areas-de-atuacao/exploracao-e-producao-de-petroleo-e-gas/presal/, 2016. Acesso em: junho de 2016.

[4] WILLIAMSON, R.; SANDERS, W.; JAKABOSKY, T.; SERIO, M.; GRIFFITH, J. E. ; OTHERS. Control of contained-annulus fluid pressure buildup. 2003.

[5] ADAMS, A.; MACEACHRAN, A. ; OTHERS. Impact on casing design of thermal expansion of fluids in confined annuli. SPE Drilling \& Completion, 9(03):210-216, 1994.

[6] ADAMS, A.. How to design for annulus fluid heat-up. 1991.

[7] ELLIS, R.; FRITCHIE JR, D.; GIBSON, D.; GOSCH, S. ; PATTILLO, P.. Marlin failure analysis and redesign; part 2, redesign. 2002.

[8] VARGO JR, R. F.; PAYNE, M.; FAUL, R.; LEBLANC, J.; GRIFFITH, J. E. ; OTHERS. Practical and successful prevention of annular pressure buildup on the marlin project. 2002.

[9] PATtillo, P. D.; COCAleS, B. W. ; MOREY, S. C.. Analysis of an annular pressure buildup failure during drill ahead. SPE Drilling and Completion, 21(04):242-247, 2006.

[10] PATTILLO, P. D.; OTHERS. Recent advances in complex well design. SPE Drilling and Completion, 2007.

[11] OUDEMAN, P.; BACARREZA, L.. Field trial results of annular pressure behavior in a high-pressure/high-temperature well. SPE Drilling \& Completion, 10(02):84-88, 1995. 
[12] MOE, B.; ERPELDING, P.. Annular pressure buildup: what it is and what to do about it. Deepwater Technology, 21, 2000.

[13] LODER, T.; EVANS, J. H. ; GRIFFITH, J. E.. Prediction of and effective preventative solution for annular fluid pressure buildup on subsea completed wells-case study. 2003.

[14] BELlaRBY, J.; KOFOED, S. S. ; MARKETZ, F.. Annular pressure build-up analysis and methodology with examples from multifrac horizontal wells and hpht reservoirs. 2013.

[15] HASAN, A. R.; IZGEC, B. ; KABIR, C. S.. Sustaining production by managing annular-pressure buildup. SPE Production Operations, 25(02):195-203, 2010.

[16] HASAN, A. R.; IZGEC, B. ; KABIR, C. S.. Ensuring sustained production by managing annular-pressure buildup. EUROPEC/EAGE Conference and Exhibition, 2009.

[17] NELSON, K.. Aogcc will rule on annular pressure management at prudhoe bay and pressure exceeded design burst rating. Petroleum News, 8(4), 2002.

[18] SANTOS, H.; ROCHA, J.; FERREIRA, M.; LIMA, V.; SOUZA, C.; BORGES, A.; SILVA, E. ; OTHERS. Apb mitigation techniques and design procedure. 2015.

[19] FERREIRA, M. V.; DOS SANTOS, A. R.; VANZAN, V. ; OTHERS. Thermally insulated tubing application to prevent annular pressure buildup in brazil offshore fields. 2012.

[20] MELO, D.; ANJOS, J. ; OTHERS. Effects of mud compressibility on wellbore closure and annular pressure based on fem with the incorporation of fluid elements. 2015.

[21] PEREZ, H. E.. EFEITO DA FLUÊNCIA DO SAL NO CRESCIMENTO DE PRESSÃO EM ANULAR CONFINADO DE POÇOS DE PRÉ-SAL . MSc. PhD thesis, Thesis, Department of Mechanical Engineering-Pontifical University Catholic of Rio de Janeiro (PUCRio)[Portuguese], 2015.

[22] LIU, J.; FAN, H.; PENG, Q.; DENG, S.; KANG, B. ; REN, W.. Research on the prediction model of annular pressure buildup in subsea wells. Journal of Natural Gas Science and Engineering, 27:1677-1683, 2015. 
[23] HALAL, A. S.; MITCHELL, R. ; OTHERS. Casing design for trapped annular pressure buildup. SPE Drilling \& Completion, 9(02):107-114, 1994.

[24] OUDEMAN, P.; KEREM, M.. Transient behavior of annular pressure build-up in hp/ht wells. SPE Drilling \& Completion, 21(04):234-241, 2006.

[25] POIATE JR, E.. Mecânica das Rochas e Mecânica Computacional para Projeto de Poços de Petróleo em Zonas de Sal. DSc. PhD thesis, Thesis, Department of Civil Engineering-Pontifical University Catholic of Rio de Janeiro (PUC-Rio)[Portuguese], 2012.

[26] WARREN, J. K.. Evaporite sedimentology. A, 1989.

[27] POIATE JR, E.; MAIA, A.; FALCAO, J. L. ; OTHERS. Well design for drilling through thick evaporite layers. 2006.

[28] MELO, D.; FONTOURA, S.; INOUE, N.; ANJOS, J. ; OTHERS. Finite element analysis of casing-in-casing integrity due to annulus pressurization by means of salt creep. 2015.

[29] CHEATHAM JR, J.; MCEVER, J. ; OTHERS. Behavior of casing subjected to salt loading. Journal of Petroleum Technology, 16(09):1069, 1964.

[30] BeltraO, R. L. C.; SOMBRA, C. L.; LAGE, A. C. V.; NeTTO, J. R. F.; HENRIQUES, C. C. D. ; OTHERS. Ss: Pre-salt santos basin-challenges and new technologies for the development of the pre-salt cluster, santos basin, brazil. 2009.

[31] FIRME, P.. Modelagem Constitutiva e Análise Probabilística Aplicadas a Poços em Zonas de Sal. PhD thesis, MSc. Dissertation, Department of Civil Engineering-Pontifical University Catholic of Rio de Janeiro (PUC-Rio)[Portuguese], 2013.

[32] CASTRO, J. D.; MEGGIOLARO, M. A.. Fadiga: técnicas e práticas de dimensionamento estrutural sob cargas reais de serviço. Volumes I e II, ISBN, p. 978-1449514709, 2009.

[33] MAIA, C.; POIATE, J.; FALCÃO, J. L.; COELHO, L. ; OTHERS. Triaxial creep tests in salt applied in drilling through thick salt layers in campos basin-brazil. 2005. 
[34] COSTA, A.; POIATE JR, E.; AMARAL, C.; PEREIRA, A.; MARTHA, L.; GATTASS, M. ; ROEHL, D.. Geomechanics applied to the well design through salt layers in brazil: A history of success. In: MULTISCALE AND MULTIPHYSICS PROCESSES IN GEOMECHANICS, p. 165-168. Springer, 2011.

[35] FINDLEY, W. N.; LAI, J. S. ; ONARAN, K.. Creep and relaxation of nonlinear viscoelastic materials. Journal of Applied Mechanics, 1976.

[36] CAVALCANTE, A. D. S.. Modelagem numérica de escavações de túneis em maciços evaporíticos. PhD thesis, Universidade de São Paulo, 2012.

[37] MUNSON, D.. Constitutive model of creep in rock salt applied to underground room closure. International Journal of Rock Mechanics and Mining Sciences, 34(2):233-247, 1997.

[38] COSTA, A. M.. Uma aplicação de métodos computacionais e princípios de mecânica das rochas no projeto e análise de escavações subterrâneas destinadas à mineração subterrânea. $\mathrm{PhD}$ thesis, Tese De Doutorado, Coppe/Ufrj, 1984.

[39] ROCHA, L. A. S.; AZEVEDO, C. T. D.. Projetos de poços de petróleogeopressões e assentamento de colunas de revestimentos. Editora Interciência: PETROBRAS, Rio de Janeiro, 2007.

[40] ABAQUS, U. M. V.. 6.14. Providence: Hibbit Karlsson and Sorensen, 2015.

[41] FJAER, E.; HORSRUD, P.; RAAEN, A.; RISNES, R. ; HOLT, R.. Petroleum related rock mechanics, volumen 33. Elsevier, 1992.

[42] $\mathrm{KIRSCH}, \mathrm{G}$.. Die theorie der elastizität und die bedürfnisse der festigkeitslehre. Springer, 1898.

[43] JANDHYALA, S. R. K.; CHINEY, A.. Finite element approach to predict the effect of annular pressure buildup on wellbore materials. 2014. 